\title{
Phytochemicals in Prostate Cancer: From Bioactive Molecules to Upcoming Therapeutic Agents
}

\author{
Bahare Salehi $^{1}$ (D), Patrick Valere Tsouh Fokou ${ }^{2}$ (D), Lauve Rachel Tchokouaha Yamthe ${ }^{3}$, \\ Brice Tchatat Tali ${ }^{4}$, Charles Oluwaseun Adetunji ${ }^{5}$, Amirhossein Rahavian ${ }^{6}$, \\ Fhatuwani Nixwell Mudau ${ }^{7}$ (D), Miquel Martorell ${ }^{8, *}$ (D), William N. Setzer ${ }^{9}$ (D),

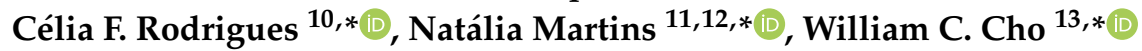 \\ and Javad Sharifi-Rad $14, *$ (D)
}

1 Student Research Committee, School of Medicine, Bam University of Medical Sciences, Bam 44340847, Iran

2 Antimicrobial and Biocontrol Agents Unit, Department of Biochemistry, Faculty of Science, University of Yaounde I, Ngoa Ekelle, Annex Fac. Sci, Yaounde 812, Cameroon

3 Institute for Medical Research and Medicinal Plants Studies, Yaoundé 13033, Cameroon

4 Antimicrobial Agents Unit, Laboratory for Phytobiochemistry and Medicinal Plants Studies, Department of Biochemistry, Faculty of Science, University of Yaoundé I, Messa-Yaoundé 812, Cameroon

5 Applied Microbiology, Biotechnology and Nanotechnology Laboratory, Department of Microbiology, Edo University, Iyamho, Edo State 300271, Nigeria

6 Department of Urology, Shohada-e-Tajrish Hospital, Shahid Beheshti University of Medical Sciences, Tehran 1989934148, Iran

7 Department of Agriculture and Animal Health, University of South Africa, Private Bag X6, Florida 1710, South Africa

8 Department of Nutrition and Dietetics, Faculty of Pharmacy, University of Concepcion, Concepcion 4070386, Chile

9 Department of Chemistry, University of Alabama in Huntsville, Huntsville, AL 35899, USA

10 LEPABE-Department of Chemical Engineering, Faculty of Engineering, University of Porto, Rua Dr. Roberto Frias, s/n, 4200-465 Porto, Portugal

11 Faculty of Medicine, University of Porto, Alameda Prof. Hernâni Monteiro, 4200-319 Porto, Portugal

12 Institute for Research and Innovation in Health (i3S), University of Porto, 4200-135 Porto, Portugal

13 Department of Clinical Oncology, Queen Elizabeth Hospital, Hong Kong, China

14 Zabol Medicinal Plants Research Center, Zabol University of Medical Sciences, Zabol 61615-585, Iran

* Correspondence: mmartorell@udec.cl (M.M.); c.fortunae@gmail.com (C.F.R.); ncmartins@med.up.pt (N.M.); williamcscho@gmail.com (W.C.C.); javad.sharifirad@gmail.com (J.S.-R.); Tel.: +56-41-266-1671 (M.M.); +351-22-5081400 (C.F.R.); +351-22-5512100 (N.M.); +852-3506-6284 (W.C.C.); +98-21-8820-0104 (J.S.-R.)

Received: 14 May 2019; Accepted: 27 June 2019; Published: 29 June 2019

\begin{abstract}
Prostate cancer is a heterogeneous disease, the second deadliest malignancy in men and the most commonly diagnosed cancer among men. Traditional plants have been applied to handle various diseases and to develop new drugs. Medicinal plants are potential sources of natural bioactive compounds that include alkaloids, phenolic compounds, terpenes, and steroids. Many of these naturally-occurring bioactive constituents possess promising chemopreventive properties. In this sense, the aim of the present review is to provide a detailed overview of the role of plant-derived phytochemicals in prostate cancers, including the contribution of plant extracts and its corresponding isolated compounds.
\end{abstract}

Keywords: prostate cancer; medicinal plants; phytotherapy; secondary metabolites; plant formulas 


\section{Introduction}

\subsection{A Brief Overview on Prostate Cancer}

The rapid growth of chronic diseases over the past century, including cancers, has emerged as among the most difficult situations for public health systems in underdeveloped and developing countries [1]. Cancer is one of the most prominent health issues in all countries due to its growing prevalence, mortality rate and high treatment cost in both genders and in all ages. In general, cancer remains not only a cause of tremendous damage to health but also the second leading cause of morbidity worldwide [2,3].

Cancer is caused by uncontrolled cell proliferation that can take place in different tissues and spread into surrounding and distant tissues [4]. Despite the main progress made in cancer biology, cancer remains one of the principal causes of mortality, and those who survive can experience permanent complications (e.g., physical, cognitive, psychosocial struggles, and treatment side effects) $[5,6]$. It is of great concern to note that cancer is a widespread disease and diagnoses are sharply increasing globally. Many risk factors are mentioned for this rise and lifestyle changing play the most important role [7].

Oncology studies have shown several types of cancer that are commonly diagnosed, including prostate, lung/bronchus, colorectal, breast, stomach, and liver cancer [8]. Although there is some variation in cancer prevalence, prostate cancer was the most commonly diagnosed cancer in the United States of America (USA), Europe and Oceania in 2012 [9]. In the past decade, much attention has been focused on prostate cancer [10] due to the alarming number of patients and the high mortality rate [11,12]. In fact, prostate cancer is the second most deadly malignancy in men after skin cancer [13]. Also, it is the most frequently diagnosed cancer among men, with a high mortality rate. About 1.6 million new cases of prostate cancer were diagnosed in 2015, and 366,000 deaths were reported [14]. In comparison to 2012, there was an increase of about $45 \%$ in incidence and $19 \%$ in mortality rate [15-18]. According to the American Cancer Society, the risk of cancer diagnosis in men in their lifetime is 1 in 9, and about 1 man in 41 will die due to prostate cancer [19].

The prostate is a glandular organ found under the bladder composed of epithelial cells arranged in a fibromuscular stromal network [20]. Although it has been difficult to establish the definitive etiological clues linking prostate cancer development to incidence, several studies have consistently linked the disease with common risk factors, namely age, race, dietary and physical activity $[8,21]$. Prostate cancer incidence is, in essence, influenced by age since the risks of being diagnosed with it increases with age [22]. Apart from age and race, Attard et al. [10] have reported that family history, for example a first-degree relative (e.g., father, son, or brother) with prostate cancer has surfaced as the greatest risk factor. According to Pandey, et al. [23], either genetic or somatic mutations contribute $10 \%$ or less to the causes of prostate cancer, whilst the remaining $90 \%$ has been attributed to epigenetic changes such as lifestyle. However, it is evident that a process that associates risk factors with cancer is inflammation [24]. In order to understand the significant role of inflammation in cancer, it is important to unpack the physiological and pathological processes attributed to inflammation.

Early detection of prostate cancer, like other malignancies, is important for better management and to prevent mortality and reduce morbidity rates, so many studies have been conducted to evaluate the risk of prostate cancer based on signs and symptoms [25]. Some of them have concentrated on lower urinary tract symptoms (LUTS) like hesitancy, nycturia, urinary retention and frequency, but almost all of them concluded that there are no signs and symptoms that are highly predictive of prostate cancer [26] and because it is vital for primary care providers and family physicians to suspect prostate cancer in patients who developed LUTS, it recommended that prostate-specific antigen (PSA) screening, but also digital rectal examination (DRE) should be performed for all of these patients and if any abnormalities detected, patients should be referred to urologists for complementary work-up and distinguishing between prostate cancer and benign prostatic hyperplasia [27,28].

PSA measurement was introduced in 1987 to verify the response to prostate cancer treatment, but was soon adopted for prostate cancer screening too $[29,30]$ and after widespread use of PSA as 
a screening test, a dramatic rise in incidence was reported from 1989 to 1992 and from 1995 this rise continued with a slight slope until 2001 and after that has fluctuated year to year revealing changes in screening practices [31]. After prostate cancer screening with PSA started in 1991 mortalities have declined and this may be due to early detection and proper management of patients [32]. The cut-off point of $4.0 \mathrm{ng} / \mathrm{mL}$ was considered for PSA screening and studies have shown that with this threshold the negative predictive value of PSA for detecting prostate cancer is $89 \%$ in men with a median age of 69 years [33], so patients with PSA levels $>4 \mathrm{ng} / \mathrm{mL}$ in two tests should undergo other work-up like prostate biopsy, multiparametric MRI [34] and whole body bone scans [35]. On the other hand, PSA is not entirely specific for prostate cancer, and other conditions, such as prostatitis, urinary tract infection (UTI), older age, benign prostate hyperplasia (BPH) and bicycle riding can cause elevations in PSA levels, and some medications, like $5 \alpha$-reductase inhibitors, aspirin, thiazide and statins cause decreases in PSA levels [13,36]. Furthermore, most prostate cancers are not harmful if not diagnosed and treated, and using PSA for diagnosis for prostate cancer results in over-diagnosis and over- treatment, so nowadays there is a vigorous debate about the usefulness of PSA screening for early detection of prostate cancer $[37,38]$. As a result, researchers have introduced other biomarkers for prostate cancer, such as free PSA, human kallikerin 2, prostate cancer antigen 3, prostate-specific membrane antigen, etc. [39] to better diagnose prostate cancer and avoid over-diagnosis and over- treatment, but there is a public consensus that with evaluation of patient risk factors, physicians can separate high-risk patients and focus on them to not miss any significant cancer, in addition, to decline over-treatment and diagnosis $[14,40]$.

Prostate cancer is a heterogeneous disease, so to anticipate the behavior of cancer, evaluating risk factors is very important [41]. Epidemiological studies have consistently emphasized the notion that naturally-occurring dietary agents possess chemopreventive properties and could easily suppress several malignancies, including that of the prostate [15]. However, there has been an inconsistency regarding a recommended plant-based diet, related nutrients, phytochemicals and prostate health [42]. In this sense, the aim of the present review is to provide a detailed overview of the physiopathology of prostate cancer, including the main risk factors and current therapeutic strategies, and of the role of plant-derived phytochemicals, including plant extracts and its corresponding isolated compounds, in prostate cancer.

\subsection{Prostate Cancer: Main Risk Factors}

The main risk factors can be stratified into two groups: non-modified and modified factors. Non-modified factors are age, family history, ethnicity, and genetic factors [40].

\subsubsection{Non-Modified Risk Factors}

Age: Before 40 years of age, mens' risk of developing prostate cancer is low. On the other hand, men older than 55 years of age have 17 times more risk of developing prostate cancer than men $<55$ years old [43]. The mean age when prostate cancer is detected in the United States is 66 years old [44].

Ethnicity: Incidence (60\%) and mortality rate (2.4 times) of prostate cancer in African-American men is higher than for other races, and Hispanic men, Asian/Pacific Islanders, American Indian/Alaskan Natives are in lower risk of developing prostate cancer [44] and it has been shown that prostate cancer incidence in men who immigrate to regions with higher prevalence rate, is higher than men in their country of origin and this increase depends on the length of stay in that area $[45,46]$.

Family and genetic factors: Patients with a positive prostate cancer family history have a higher risk of having this disorder than others, especially a positive history among first degree relatives and in multiple relatives and under 65 years old [47]. Until now more than 105 loci show that increased risk of prostate cancer have been identified, suggesting about $30 \%$ of heritability [48,49]. Table 1 showed the relative risk of a family history of prostate cancer $[47,50]$. 
Table 1. Relative risk of prostate cancer in patients with a positive family history.

\begin{tabular}{cc}
\hline Risk Group & Relative Risk of Prostate Cancer \\
\hline Father and brother had prostate cancer & 9 \\
$\geq 2$ first degree relatives having prostate cancer & 4.39 \\
Brothers having prostate cancer & 3.14 \\
First degree relative with prostate cancer at the age of $<65$ & 2.87 \\
Second degree relative with prostate cancer & 2.52 \\
One first degree relative with prostate cancer & 2.48 \\
Father having prostate cancer & 2.35 \\
First degree relative with prostate cancer at the age of $\geq 65$ & 1.92 \\
\hline
\end{tabular}

Height: Another factor that increases prostate cancer risk is height. Taller men are in greater risk of progressive prostate cancer, not total prostate cancer [51] and an overall relative risk of 1.19 has been estimated for prostate cancer per $10 \mathrm{~cm}$ increase in height [52].

\subsubsection{Modified Risk Factors}

Obesity: There is no clear relationship between obesity (body mass index (BMI) $>25 \mathrm{~kg} / \mathrm{m}^{2}$ [53]) and increased risk of prostate cancer, but it is proven that obese men are at higher risk of advanced prostate cancer and biochemical recurrence [54,55], and also recent studies showed that risk of recurrence in patients who have weight gain after radical prostatectomy (RP) is higher [56]. Risk of advanced prostate cancer is six times higher than for non-obese men [43] and the risk of mortality increases by $20 \%$ for every $5 \mathrm{~kg} / \mathrm{m}^{2}$ increase in BMI [54]. The importance of this issue is highlighted by the fact that we know that the world's obese population has at least doubled since 1980 [57] and this can be due to lifestyle changes of patients that have resulted in lower physical activity and higher fat and red meat intake. Physical activity, especially vigorous activity, decreases prostate cancer risk, advance prostate cancer, mortality and recurrence of prostate cancer, and increases survival and it has been shown that physical activity for at least $3 \mathrm{~h} /$ week, even jugging and brisk walking, decreases cancer-specific mortality rate [58-60]. On the other hand, an inactive lifestyle has been related to higher PSA [60]. Many studies have revealed that higher intakes of fat, red meat, and dairy foods increase the risk of prostate cancer, but it is not proven yet. Dairy products contain a lot of fat and calcium, and high consumption of calcium increases the risk of prostate cancer, and this is probably due to disturbance of the metabolism of vitamin D [61], but non-dairy calcium intake does not change prostate cancer risk [62]. A 2012 study showed that high amounts of red meat and dairy foods elevate the prostate cancer risk 12-fold [63], and there is no specific amount for daily calcium intake, but some studies revealed that consumption of calcium $>2000 \mathrm{mg}$ /day raises the risk of prostate cancer [64].

Infectious disease: Infections and chronic inflammation leading to cellular damage and hyperproliferation cause $16 \%$ of worldwide malignancies [65] and some studies have revealed that UTI, sexually transmitted diseases and prostatitis could cause the development of prostate cancer via this mechanism, but it is uncertain $[40,66]$. At present, no specific infectious agent has been proven to cause prostate cancer. However, some evidence for the role of Trichomonas vaginalis in prostate cancer has been shown [67].

Occupational and external exposure: some jobs have a higher risk of prostate cancer due to exposure to specific materials, for example farmers who are exposed to pesticides and other chemical materials have a two times higher risk of prostate cancer $[18,68]$ and also higher exposure to sunlight due to UV and ionizing radiation is related to an increased risk of prostate cancer $[69,70]$.

Smoking: Cigarette smokers have a higher probability of developing prostate cancer, including advanced and hormone resistant forms, spreading metastasis and higher mortality rates and it depends on the amount (pack/year) and duration of smoking and it showed that the risk of mortality and recurrence of prostate cancer in former smoker patients, who quit smoking 10 years before diagnosing prostate cancer is similar to that of non-smoking patients [58]. Some researchers are 
interested in the association among prostate cancer and alcohol intake, and many studies on this topic have been done, but mixed results were obtained, although one case-control study revealed that heavy drinkers have lower PSA levels and are in higher risk of advanced disease at detection [71,72].

Endogenous hormones: Androgens cause the proliferation and differentiation of the luminal epithelium of the prostate and play a key role in prostate carcinogenesis and establishing cancer, and because of these facts many patients respond to androgen deprivation treatment. For a long time, researchers believed that high serum androgen level was a risk factor of prostate cancer, but the last pooled analysis could not find any link between prostate cancer and serum androgen levels, but it found a connection among sex-hormone-binding globulin serum concentration and cancer risk [73]. Previously estrogens were a choice of treatment in castration-resistant prostate cancer and have been considered as a protective agent for cancer, but recently more studies have presented evidence for a pro-carcinogenic effect of estrogen on prostate cancer and shown that early exposure to estrogens increases the risk of later prostate cancer [74,75]. A pooled analysis in 2008 showed a strong connection between insulin-like growth factor-I and the risk of prostate cancer [76], but epidemiologic studies reviewed in 2011 revealed mixed findings, although they suggested that the insulin-like growth factor axis affects cancer progression rather than initiation [77]. The core genetic changes that cause activation of oncogenes and inactivation of tumor suppressors are responsible for the start and progression of prostate cancer, and epigenetic and structural genomic changes like deletion, chromosomal rearrangement, and amplification that result in gene fusion with new biologic functions are responsible for these changes. Chromatin remodeling, hypomethylation and promotor methylation that cause epigenetic regulation of gene expression play a significant part in the development and evolution of prostate cancer. Androgen receptors (AR) play a key role in prostate cancer, and changes in ARs like amplification, mutations, and ligand promiscuity are determining factors in progressive castrate-resistant prostate malignancies because these changes sensitize the ARs to low levels of intra-tumoral androgen [78]. The basic drivers for the initiation of prostate cancer are based on gene fusions of TMPRSS2 and the ETS family oncogenic transcription factors [79].

\section{Therapeutic Strategies: A Brief Summary}

To properly treat prostate cancer, patients should undergo full evaluation, including DRE, checking PSA and LFT, life expectancy and comorbidity evaluation, abdominal-pelvic CT, MRI and radionuclide bone scans if needed, and based on these data and characterizations of tumor (Table 2), including clinical stage, Gleason score, tumor volume, invasion and metastasis, patients are stratified into low, intermediate, high and very high risk groups and the cancer divided to localized, locally advance and metastatic prostate cancer [80-82].

Table 2. Classification of the risk groups of prostate cancer [83].

\begin{tabular}{ccccc}
\hline Risk Group & Clinical Stage & PSA (ng/mL) & Gleason Score & Biopsy Criteria \\
\hline Low & T1a or T1c & $<10$ & $2-6$ & Unilateral or $<50 \%$ of core involved \\
\hline Intermediate & T1b, T1c, or T2a & $<10$ & $3+4=7$ & Bilateral \\
\hline High & T1b, T1c, T2b, or T3 & $10-20$ & $4+3=7$ & $\begin{array}{c}>50 \% \text { of core involved or perineural } \\
\text { invasion or ductal differentiation }\end{array}$ \\
\hline Very high & T4 & $>20$ & $8-10$ & $\begin{array}{c}\text { Lymphovascular invasion or } \\
\text { neuroendocrine differentiation }\end{array}$ \\
\hline
\end{tabular}

There are some established options for treating prostate cancer, like watchful waiting (WW), active surveillance (AS), radiation therapy (RT), hormone therapy (HT), and radical prostatectomy (RP) [80]. The goal of conservative management (AS, WW) is to reduce over-treatment [81]. In WW, patients are followed until new symptoms appear or get worse [80], so WW is suitable for poor prognosis patients with low life expectancy [81]. AS is suitable for low-risk prostate cancer or patients with $<5$ years life expectancy and in AS, physicians monitor patients closely and some periodic work- 
ups like DRE, PSA checking, prostate biopsy, and MRI are done, and every time the evidence is in favor of cancer progression, patients then become candidates for other definite treatments $[80,84]$. RP is the first option introduced for treating prostate cancer [85], and it remains a typical form of management because it is the only method that cures the prostate cancer and the goal of RP is to eradicate cancer while conserving urinary continence and if possible potency [81]. Patients with intermediate and high-risk prostate cancer and life expectancy $>5$ years are good candidates for RP, and RT is an option for managing almost all prostate cancer groups alone or with another modality, except got low and intermediate risk prostate cancer patients with low life expectancy ( $<5$ years) [84]. RT and RP are the most common methods for managing prostate cancer, and so far, no study has establish the superiority of one of these two methods over the other and complications in both methods are common, and also there are no significant differences between the survival rates of these two methods [80]. There are different approaches for RP, including perineal, retropubic, laparoscopic and robotic, but until now there is no clear evidence that any one of this methods is better than the others in cancer control, cancer-related urinary continence and erectile function conservation, although some poorly designed studies have revealed that robot-assisted RP is better than laparoscopic methods in reducing positive surgical margins [86]. The most popular methods for RT that could be accompanied with HT are external beam radiotherapy and brachytherapy that have side effects like rectal and bladder toxicity and these side effects are more common in external beam radiotherapy. Other treatments like cryoablation and high-intensity focused ultrasound ablation have been introduced, but there is no proof to support their superiority $[83,87]$. Finally, physicians should choose the proper treatment based on tumor characterization and the patient's condition after the acceptance of the patient [88].

Many prostate cancer patients have more progressive disease, and management of these patients is different. In patients with symptomatic non-metastatic prostate cancer who are not candidates for curative treatment and patients with symptomatic metastatic prostate cancer, androgen deprivation therapy (ADT) is an option for palliative therapy, but we should not use ADT on patients with asymptomatic locally advanced prostate cancer or biochemical recurrence after curative therapy $[82,89]$. There are several methods for ADT. The gold standard is bilateral orchiectomy that diminishes the testosterone level below $15 \mathrm{ng} / \mathrm{dL}$ on average [90] but this has some disadvantages like irreversibility, physical and psychological pressure on the patients, so HT was introduced [91]. Luteinizing hormone-releasing hormone (LH-RH) agonists (leuprolide, goserelin, triptorelin) and antagonists (degarelix, abiraterone), non-steroidal antiandrogens (bicalutamide, flutamide, nilutamide) are three major drug categories used for ADT with LH-RH agonists being more prevalent, but the risk of flare phenomena is lower when using a LH-RH antagonist [91,92]. Intermittent or continuous ADT are two separate methods for managing systemic prostate cancer, but there is no difference between overall survival and cancer-specific survival of these two methods [82].

It is likely that after any curative management patients eventually relapse, that includes rising PSA or nodal involvement. If patients develop rising PSA after RP, the European Association of Urology guidelines advise early salvage radiotherapy (SRT) [82] and some retrospective studies have revealed that adding ADT to early SRT had some benefits in biochemical progression-free survival after 5 years [93]. In patients with PSA relapsing after RT, salvage RP is the first choice for local control of cancer. Salvage RP increases the risk of anastomotic stricture, urinary incontinence, erectile dysfunction, and rectal injury, so other alternative methods are available, like salvage cryoablation, high and low dose rates brachytherapy [82,94]. For management of nodal relapse, surgical and salvage lymph node dissection (LND) is the only choice. There are no specific criteria for candidate patients for salvage LND, but this should be considered and this method should be used for highly selected patients [82,95].

As we said, patients with the progressive disease can be managed with ADT, but some of these patients develop castration resistance, that is, castrated serum testosterone is less than $50 \mathrm{ng} / \mathrm{dL}$, and the patient has biochemical or radiologic progression [96]. First-line treatment for this situation is abiraterone, enzalutamide or docetaxel (DX)-based chemotherapy and second-line treatment options depend on the chosen first-line treatment. If the patient was treated with abiraterone or enzalutamide as first-line 
treatment, DX-based chemotherapy is the next option and vice versa. If DX-based chemotherapy was used first and the patient responded, we can repeat this chemotherapy regimen again, but there is usually no improvement in the survival of patients [82,97]. Most of these patients developed with painful bone metastasis, but external-beam radiotherapy is very effective in relieving pain [98]. Finally, it is important to say that managing these patients needs teamwork, and the urologist, oncologist, psychologist, nurse, and even social workers should work together to manage patients properly [99].

Prostate cancer, like the other cancers, is an expensive disease and imposes a great burden on both the health system and patients, and these expenditures are increasing year by year which may due to over-treatment, over work-up or over-diagnosis and increased survival [100]. In 2010, the budget expended for prostate cancer care in the United States was 11.8 billion dollars, and in 2013 and 2017 this budget was $\$ 13.0$ and $\$ 14.8$ billion, respectively [101]. In Iran, direct medical costs for prostate cancer were estimated at about 12.5 million USD in 2016 for about 500 patients [102] and the cost for metastatic castration-resistant prostate cancer in Italy in 2016 ranged from €196.5-228.0 million [103]. These cost variations may be due to differences in incidence and management protocols between countries [100], and most of these monies were expended for treatment [103], so having preventive strategies and using natural products for managing prostate cancer patients it is possible to markedly decrease the economic burden of this disease.

\section{Plant Extracts and Plant-Derived Bioactives in Prostate Cancer}

Traditional plants have been used to treat and cure various diseases [104], and this has led to increased use of medicinal plants in the search for new drugs from nature [105]. The discovery of new drugs is often established based on the knowledge that plant extracts can be used to treat diseases in humans. The plants are potential sources of natural bioactive compounds that are, but not limited to, secondary metabolites [106]. Cragg and Newman [107] have stated that any part of a plant such as leaves, bark, flowers, and seeds may contain these secondary metabolites. Although little is known of the primary processes of the secondary metabolites in plants, Bodeker [108] reported that secondary metabolites are essential and important in plant use by people. In this regard, herbal medicines, which have been increasingly used in cancer treatment, represent a rich pool of new and bioactive chemical entities for the development of chemotherapeutic agents with many exhibiting favorable side effect and toxicity profiles compared to conventional chemotherapeutic agents [6,109]. In this sense, in the following section the plant extracts and corresponding bioactive constituents with anti-prostate cancer potential are carefully described. Lastly, a special emphasis on clinical studies confirming the plant-derived phytochemicals anti-prostate cancer potential is also given.

\subsection{Plant Extracts with Anti-Prostate Cancer Potential}

Among the plant extracts with anti-prostate cancer potential (Table 3), the most remarkable ones belong to the Annonaceae, Apocynaceae, Asteraceae, Combretaceae, Euphorbiaceae, Fabaceae, Lamiaceae, Malvaceae, Phyllantheraceae, Poaceae, Rutaceae, Solanaceae and Zingiberaceae families (Figure 1).

Table 3. Medicinal plants with anti-prostate cancer effects.

\begin{tabular}{ccccc}
\hline Plant Species & Family & In Vitro & In Vivo & References \\
\hline Acacia catechu & Fabaceae & + & - & {$[110]$} \\
Achillea santolinoides & Asteraceae & + & - & {$[111]$} \\
Achillea teretifolia & Asteraceae & + & - & {$[112]$} \\
Allium wallichii & Amaryllidaceae & + & - & {$[113]$} \\
Aloe perryi & Xanthorrhoeaceae & + & - & {$[114]$} \\
Anaxagorea brevipes & Annonaceae & + & - & {$[115]$} \\
Angelica gigas & Apiaceae & - & + & {$[116,117]$} \\
Annona muricata & Annonaceae & + & - & {$[118]$} \\
Anogeissus latifolia & Combretaceae & + & - & {$[110]$} \\
Apocynum venetum & Apocynaceae & + & - & {$[119]$} \\
\hline
\end{tabular}


Table 3. Cont.

\begin{tabular}{|c|c|c|c|c|}
\hline Plant Species & Family & In Vitro & In Vivo & References \\
\hline Arachis hypogaea & Fabaceae & + & - & [120] \\
\hline Baliospermum montanum & Euphorbiaceae & + & + & [121] \\
\hline Berberis libanotica & Berberidaceae & + & - & [122] \\
\hline Byrsonima crassifolia & Malpighiaceae & + & - & [123] \\
\hline Calliandra portoricensis & Fabaceae & + & - & [124] \\
\hline Capsicum chinense & Solanaceae & + & - & [123] \\
\hline Carica papaya & Caricaceae & + & - & [125] \\
\hline Cascabela peruviana & Apocynaceae & + & - & [126] \\
\hline Chenopodium hybridum & Amaranthaceae & + & - & [127] \\
\hline Cnidoscolus chayamansa & Euphorbiaceae & + & - & [123] \\
\hline Cornus mas & Cornaceae & + & - & [128] \\
\hline Costus pulverulentus & Costaceae & + & - & [129] \\
\hline Crataegus Pinnatifida & Rosaceae & + & - & [130] \\
\hline Crocus sativus & Iridaceae & + & + & [131-133] \\
\hline Curcuma longa & Zingiberaceae & + & - & {$[131,134]$} \\
\hline Cymbopogon citratus & Poaceae & + & - & [135] \\
\hline Cymbopogon giganteus & Poaceae & + & - & [135] \\
\hline Euphorbia microsciadia & Euphorbiaceae & + & - & [111] \\
\hline Euphorbia szovitsii & Euphorbiaceae & + & - & [111] \\
\hline Eurycoma longifolia & Simaroubaceae & + & + & [136] \\
\hline Fagara zanthoxyloides & Rutaceae & + & - & [137] \\
\hline Fagopyrum esculentum & Polygonaceae & + & - & [138] \\
\hline Fagopyrum tataricum & Polygonaceae & + & - & [138] \\
\hline Ficus deltoidea var. angustifolia & Moraceae & + & - & [139] \\
\hline Ficus deltoidea var. deltoidea & Moraceae & + & - & [139] \\
\hline Formosa lambsquarters & Amaranthaceae & + & - & [138] \\
\hline Glycine max & Fabaceae & + & - & [140] \\
\hline Glycyrrhiza uralensis & Fabaceae & + & - & [141] \\
\hline Haplophyllum perforatum & Rutaceae & + & - & [111] \\
\hline Helicteres hirsuta & Malvaceae & + & - & [142] \\
\hline Hertia angustifolia & Asteraceae & + & - & [111] \\
\hline Hibiscus sabdariffa & Malvaceae & + & + & [143] \\
\hline Leucaena leucocephala & Fabaceae & + & - & [123] \\
\hline Lysimachia ciliata & Primulaceae & + & - & [144] \\
\hline Malmea depressa & Annonaceae & + & - & [123] \\
\hline Maytenus royleana & Celastraceae & + & + & [145] \\
\hline Medicago sativa & Fabaceae & + & - & [111] \\
\hline Melissa officinalis & Lamiaceae & + & - & {$[146,147]$} \\
\hline Mentha arvensis & Lamiaceae & + & - & [148] \\
\hline Mentha spicata & Lamiaceae & + & - & [148] \\
\hline Mentha viridis & Lamiaceae & + & - & [148] \\
\hline Moringa oleifera & Moringaceae & + & - & [110] \\
\hline Nepeta cataria & Lamiaceae & + & - & [149] \\
\hline Nigella sativa & Ranunculaceae & + & - & {$[131,150]$} \\
\hline Oryza sativa & Poaceae & + & - & [151] \\
\hline Paeonia lactiflora & Paeoniaceae & + & - & [152]. \\
\hline Paramignya trimera & Rutaceae & + & - & [153] \\
\hline Phyllanthus amarus & Phyllanthaceae & + & - & [154] \\
\hline Phyllanthus niruri & Phyllanthaceae & + & - & [154] \\
\hline Phyllanthus urinaria & Phyllanthaceae & + & - & [154] \\
\hline Phyllanthus watsonii & Phyllanthaceae & + & - & [154] \\
\hline Plumbago zeylanica & Plumbaginaceae & + & - & [155] \\
\hline Polygonatum sp & Asparagaceae & + & - & [156] \\
\hline Pseudocedrela kotchyi & Meliaceae & + & - & [137] \\
\hline Psidium guajava & Myrtaceae & + & + & {$[138,157,158]$} \\
\hline Punica granatum & Lythraceae & + & + & {$[5,159-161]$} \\
\hline Quisqualis indica & Combretaceae & + & + & [162] \\
\hline Remotiflori radix & Campanulaceae & + & + & [163] \\
\hline Salvia multicaulis Vahl & Lamiaceae & + & - & [111] \\
\hline Salvia trilobal & Lamiaceae & + & - & [164] \\
\hline
\end{tabular}


Table 3. Cont.

\begin{tabular}{ccccc}
\hline Plant Species & Family & In Vitro & In Vivo & References \\
\hline Sigesbeckia orientalis & Asteraceae & + & - & {$[165]$} \\
Sophora alopecuroides & Fabaceae & + & - & {$[111]$} \\
Sutherlandia frutescens & Fabaceae & + & + & {$[166]$} \\
Terminalia bellerica & Combretaceae & + & - & {$[110]$} \\
Terminalia catappa & Combretaceae & + & - & {$[123]$} \\
Urtica dioica & Urticaceae & + & - & {$[111,167]$} \\
Vitis rotundifolia & Vitaceae & + & - & {$[168]$} \\
Wedelia chinensis & Asteraceae & - & + & {$[169,170]$} \\
Withania coagulans & Solanaceae & - & + & {$[171]$} \\
Xylopia aethiopica & Annonaceae & + & - & {$[172]$} \\
Zanthoxylifructus & Rutaceae & + & + & {$[173]$} \\
Zingiber officinale & Zingiberaceae & + & + & {$[131,174,175]$} \\
\hline
\end{tabular}

+: Showed in vitro or in vivo antiproliferative effect; -: Not found.

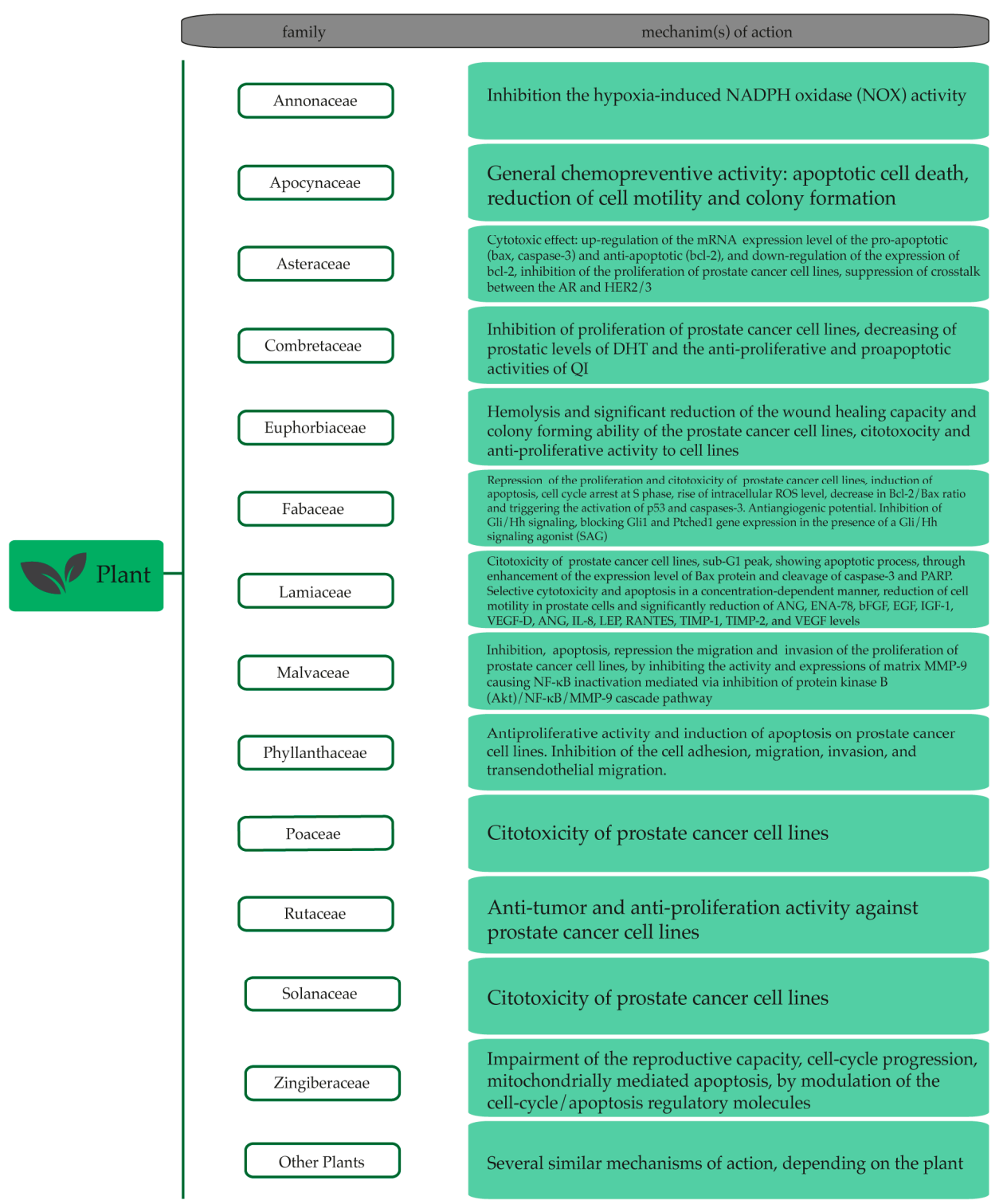

Figure 1. Plant species with anti-prostate cancer potential and its respective modes of action. 


\subsubsection{Annonaceae Plants}

Annona muricata or graviola pulp extract $(1-5 \mu \mathrm{g} / \mathrm{mL})$ containing acetogenins strongly inhibited the hypoxia-induced NADPH oxidase (NOX) activity in prostate cancer cells (LNCaP, 22Rv1, and PC-3) viz. 22Rv1 cells by $39-98 \%$, LNCaP cells by $77-91 \%$ and in PC-3 cells by $71-75 \%$. This activity was linked to a reduction in the expression of NOX catalytic and regulatory sub-units (NOX1, NOX2, and p47(phox)), nuclear hypoxia-inducible factor (HIF)- $1 \alpha$ levels, the proliferative and clonogenic potential. Indeed, NOX expression is directly linked to prostate cancer development in TRAMP mice, suggesting NOX as a possible chemoprevention target in monitoring the disease [118]. Essential oil from leaves of Anaxagorea brevipes containing $\beta$-eudesmol (13.16\%), $\alpha$-eudesmol (13.05\%), $\gamma$-eudesmol (7.54\%), guaiol $(5.12 \%)$, caryophyllene oxide $(4.18 \%)$ and $\beta$-bisabolene $(4.10 \%)$ exhibited high antiproliferative activity on prostate cancer cells, PC-3 $\left(\mathrm{IC}_{50}=9.6 \mu \mathrm{g} / \mathrm{mL}\right)$ [115]. Malmea depressa plants revealed cytotoxic activity in LNCaP greater than 50\% [123]. A study exhibited that the methanol extract of Xylopia aethiopica has antiproliferative activity in PC-3 and LNCaP cells ( $\mathrm{IC}_{50}=62.1$ and $73.6 \mu \mathrm{g} / \mathrm{mL}$, respectively) at $96 \mathrm{~h}$ through apoptosis, lacking anti-angiogenic properties [172].

\subsubsection{Apocynaceae Plants}

Luobuma (Apocynum venetum), a popular beverage in Asia, has bioactive compounds including sterols (lupeol, stigamasterol, and $\beta$-sitosterol) and polyphenolics (isorhamnetin, kaempferol, and quercetin), which were reported for their chemopreventive activity (e.g., anti-androgen-insensitive-prostate-cancer (anti-AIPC)). Fraction 8 inhibited the proliferation of PC-3 cells by arresting G2/M, regulation of apoptotic signal molecules (cytochrome c, Bcl-2, p53, and caspase- 3 and -8), inhibition of $\beta$-catenin signaling, and suppression DNA repair enzyme expression (uracil-DNA glycosylase) [119]. Cascabela peruviana showed an antiproliferative effect on the human prostate cancer cell line $\left(\mathrm{IC}_{50}=1.91 \mu \mathrm{g} / \mathrm{mL}\right)$. The extract containing thevetiaflavone and cardiac glycosides induced apoptotic cell death, and significantly reduced cell motility and colony formation on all evaluated cancer cell lines [126].

\subsubsection{Asteraceae Plants}

Achillea teretifolia methanol extracts exhibited a remarkable cytotoxic effect on DU145 and PC-3 cells as time and concentration increased, with up-regulation of the mRNA expression level of the pro-apoptotic (bax, caspase-3) and anti-apoptotic (bcl-2), and down-regulation of the expression of bcl-2, and might contain anticancer compounds, activating the cytotoxicity and the apoptosis on prostate cancer cells [112]. Achillea santolinoides ethanol extract showed anticancer potential against PC-3 and Du145 cells, with $\mathrm{IC}_{50}$ values of 193 and $151 \mu \mathrm{g} / \mathrm{mL}$, while that of Hertia angustifolia displayed an $\mathrm{IC}_{50}$ of $216 \mu \mathrm{g} / \mathrm{mL}$ on DU145, respectively [111]. Another study revealed that Sigesbeckia orientalis ethanol extract considerably inhibited the proliferation of LNCaP cell lines in $24 \mathrm{~h}$ with an $\mathrm{IC}_{50}=87.2 \pm 1.3 \mu \mathrm{g} / \mathrm{mL}$ [165]. Wedelia chinensis has, at least three active compounds-luteolin, wedelolactone, and apigenin - that act synergistically to inhibit prostate cancer cell growth in vitro. Tsai et al. [170] reported a standardized optimized herbal ethanolic extract of dried W. chinensis (WCE). The combination of LC/MS/MS and PSA reporter assay was suitable to measure the quality and efficacy of a standardized WCE on a xenograft tumor model. Besides, the pharmacokinetics and oral bioavailability of active compounds demonstrate that holistic WCE had extra pharmacological synergy afar the multi-targeted therapeutic effects [170]. WCE was shown to be effective in suppressing crosstalk between the AR and HER2/3 signaling in an in vivo adapted castration-resistant prostate cancer LNCaP cell model that was insensitive to androgen withdrawal and second-line antiandrogen, enzalutamide and offer evidence that the use of a clear, single plant-derived extract can increase the therapeutic efficacy of castration with expressively prolonged progression-free survival warranting further clinical studies [169]. 


\subsubsection{Combretaceae Plants}

Anogeissus latifolia and Terminalia bellerica inhibited the cell proliferation of PC-3 cell lines in a concentration-dependent manner ( $\mathrm{IC}_{50}=10.6$ and $17.7 \mu \mathrm{g} / \mathrm{mL}$, respectively) [110]. Quisqualis indica (QI) reduced (TP)-induced increase in AR and PSA expression in LNCaP. Oral administration of $150 \mathrm{mg} / \mathrm{kg}$ of QI together with the TP injection in rat protected against TP-induced BPH, as shown by the decrease decreased prostatic levels of DHT and the anti-proliferative and proapoptotic activities of QI [162]. Terminalia catappa also showed anti-proliferative activity in LNCaP with inhibition percentage superior to $50 \%$ [123].

\subsubsection{Euphorbiaceae Plants}

Baliospermum montanum is an anticancer plant used in Ayurvedic medicine [167]. Nanoparticles prepared with both aqueous and ethanolic extracts of B. montanum presented a dose and time-dependent toxicity on prostate cancer cells with cell viability of $22 \%$ and $6 \%$ with a maximum concentration of aqueous and ethanolic nanoparticles $(2 \mathrm{mg} / \mathrm{mL})$, respectively, in $48 \mathrm{~h}$. Also, no in vitro hemolysis and significant reduction of the wound healing capacity and colony forming ability of the prostate cancer cells was demonstrated [121]. Cnidoscolus chayamansa plants showed cytotoxic activity on LNCaP with a percent inhibition greater than 50\% [123]. Euphorbia microsciadia ethanol extract showed anti-prostate activity against PC-3 cells with an $\mathrm{IC}_{50}$ value of $222 \mu \mathrm{g} / \mathrm{mL}$, and that of Euphorbia szovitsii had anti-proliferative activity on both PC-3 and DU145 cells with $\mathrm{IC}_{50}$ values of 111 and $56 \mu \mathrm{g} / \mathrm{mL}$ [111].

\subsubsection{Fabaceae Plants}

Arachis hypogaea or peanut skin procyanidins (PSP) and six fractions (PSP-1 6) considerably repressed the proliferation of DU145 cells. PSP-2 consisting in procyanidin $\mathrm{B}_{3}$ mainly and procyanidin dimer [(E)C-luteolin or keampferol] secondarily was the most effective fraction that induced apoptosis, cell cycle arrest at S phase, increased intracellular ROS level and decreased Bcl-2/Bax ratio and triggered the activation of p53 and caspases-3 in DU145 cells [120]. Acacia catechu inhibited the cell proliferation of PC-3 cell line in a concentration-dependent manner $\left(\mathrm{IC}_{50}=14.3 \mu \mathrm{g} / \mathrm{mL}\right)$ [110]. Calliandra portoricensis (CP) inhibited PC-3 and LNCaP growth between $7 \%$ and $92 \%$ at $48 \mathrm{~h}(10,50$ and $100 \mu \mathrm{g} / \mathrm{mL}$ ). Detection of cell death induced by CP at $50 \mu \mathrm{g} / \mathrm{mL}$ displayed superior enrichment factors in LNCaP (7.38) than PC-3 (3.48). Moreover, CP (50 $\mu \mathrm{g} / \mathrm{mL})$ notably decreased the network of vessels in CAM, proposing an antiangiogenic potential [124]. Rayaprolu et al. [140] showed in vitro bioactivity of peptide fractions of Glycine max, soybeans against PC-3 cells proliferation with up to $63.0 \%$ of inhibition $\left(\mathrm{IC}_{50}=608-678 \mu \mathrm{g} / \mathrm{mL}\right.$ ). Glycyrrhiza uralensis (licorice) extracts are known for their anti-carcinogenic properties but the presence of glycyrrhizin, a hypokalemia and hypertension agent, is detrimental. Park et al. [141] prepared a glycyrrhizin-free hexane/ethanol extract of G. uralensis that induces apoptosis and G1 cell cycle arrest and inhibits migration of DU145 cells. Leucaena leucocephala plant showed cytotoxic effects on LNCaP with a percent inhibition greater than 50\% [123]. Medicago sativa and Sophora alopecuroides ethanol extracts inhibit the growth of Du145 cells $\left(\mathrm{IC}_{50}=77\right.$ and 192 $\mu \mathrm{g} / \mathrm{mL}$, respectively) [111]. Sutherlandia frutescens methanol extract (SFE) showed an antiproliferative effect on the human prostate cancer cell lines PC-3 and LNCaP, and mouse prostate cell line TRAMP-C2 $\left(\mathrm{IC}_{50}=167 \mu \mathrm{g} / \mathrm{mL}\right.$ for PC-3, $200 \mu \mathrm{g} / \mathrm{mL}$ for LNCaP, and $100 \mu \mathrm{g} / \mathrm{mL}$ for TRAMP-C2) associated with a dose-dependent inhibition of the Gli-reporter activity in Shh Light II and TRAMP-C2QGli cells treated with SFE. Furthermore, SFE has shown to inhibit Gli/Hh signaling by blocking Gli1 and Ptched1 gene expression in the presence of a Gli/Hh signaling agonist (SAG). Additionally, diet supplementation with $S$. frutescens showed suppression of the formation of poorly differentiated carcinoma in prostates of TRAMP mice [166]. 


\subsubsection{Lamiaceae Plants}

Estrogen receptor positive PC-3 cells are more sensitive to the cytotoxic effects of Nepeta cataria in comparison with low hormone-receptor presenting DU145 cells. Among multiple extracts and essential oils, only the ethyl acetate extract could expressively decline cell viability in PC-3 cells, in a concentration-dependent way $\left(\mathrm{IC}_{50}=149.6 \mu \mathrm{g} / \mathrm{mL}\right)$ and showed a sub-G1 peak that showed apoptotic process in ethyl acetate extract-induced cells through enhancement of the expression level of Bax protein and cleavage of caspase-3 and PARP to active [149]. The aqueous extracts of whole plants of Mentha arvensis, M. spicata and M. viridis at a concentration of $100 \mu \mathrm{g} / \mathrm{mL}$ indicated growth inhibition of 75,85 , and $71 \%$ respectively against the PC-3 human cancer cell line. The results indicate that Mentha spp. have compounds with cytotoxic properties which may find use in developing anticancer agents [148]. Salvia multicaulis ethanol extract exhibited antiproliferative activity against both PC-3 and Du145 cells, with $\mathrm{IC}_{50}$ values of 240 and $143 \mu \mathrm{g} / \mathrm{mL}$, respectively [111], while Salvia triloba methanolic extract (STE) induced selective cytotoxicity and apoptosis in a concentration-dependent manner, reduced cell motility in the same cells and significantly decreased ANG, ENA-78, bFGF, EGF, IGF-1 and VEGF-D levels in STE-treated DU145 cells, while ANG, IL-8, LEP, RANTES, TIMP-1, TIMP-2, and VEGF levels were considerably reduced in PC-3 cells [164].

\subsubsection{Malvaceae Plants}

Helicteres hirsuta is an herbal medicine used in the management of diabetes and malaria. Leaf and stem extracts and its two sub-fractions (aqueous and saponin-enriched butanol fractions) displayed strong anticancer activity in vitro towards prostate cancer cell lines $\left(\mathrm{IC}_{50}=1.57-152 \mu \mathrm{g} / \mathrm{mL}\right)$ [142]. Hibiscus sabdariffa leaf extract (HLE) dose-dependently inhibited proliferation of LNCaP cells with a $50 \%$ growth inhibition value of about $3.0 \mathrm{mg} / \mathrm{mL}$ after $24 \mathrm{~h}$. HLE also caused apoptosis and repressed the migration and invasion of human prostate cancer LNCaP cells by inhibiting the activity and expressions of matrix MMP-9 causing NF- $\mathrm{KB}$ inactivation mediated via inhibition of the protein kinase B (Akt)/NF-kB/MMP-9 cascade pathway. The inhibitory effect of $50 \mathrm{mg} / \mathrm{mL}$ HLE solution in a $5 \mathrm{~g}$ diet was confirmed by the inhibition of the growth of LNCaP cells and of the expressions of metastasis-related molecular proteins in vivo in xenograft tumor mice [143].

\subsubsection{Phyllanthaceae Plants}

Phyllanthus plants (P. amarus, P. niruri, P. urinaria, and P. watsonii) have antiproliferative activity and induction of apoptosis on prostate cancer cell lines. Phyllanthus extracts showed to have notably inhibited the cell adhesion, migration, invasion, and transendothelial migration of PC-3 cells in a dose-dependent way. Additionally, low cytotoxicity on HUVECs was exhibited, suggesting a potential to inhibit tumor metastasis and angiogenesis through the suppression of metalloproteinase enzymes [154].

\subsubsection{Poaceae Plants}

Cymbopogon citratus essential oil consists mainly in limonene (19.33\%), cis-mentha-1(7),8-dien-2-ol (17.34\%), trans-mentha-1(7),8-dien-2-ol (13.95\%), trans-para-mentha-2,8-diene-1-ol $(13.91 \%)$ and cis-para-mentha-2,8-diene-1-ol (8.10\%), while Cymbopogon giganteus mainly contains geranial/citral A $(48.18 \%)$ and neral/citral B (34.37\%). C. citratus essential oil has shown to be most effective on prostate cell lines LNCaP $\left(\mathrm{IC}_{50}=6.36 \mu \mathrm{g} / \mathrm{mL}\right)$ and PC-3 $\left(\mathrm{IC}_{50}=32.1 \mu \mathrm{g} / \mathrm{mL}\right)$ vs. $160.1 \mu \mathrm{g} / \mathrm{mL}$ and $303.3 \mu \mathrm{g} / \mathrm{mL}$ for $C$. giganteus. Combining both oils, antagonist, additive, indifferent and synergistic effects were noticed on LNCaP and PC-3 cell lines [135]. Oryza sativa, Sung Yod rice is a red-violet pigmented rice produced by an expression method, demonstrated to have more benefits related to cytotoxicity against prostate cancer cells $(\mathrm{PC}-3)\left(\mathrm{IC}_{50}=52.06 \mu \mathrm{g} / \mathrm{mL}\right)$ than the one produced by Soxhlet method extracted with hexane [151]. 


\subsubsection{Rutaceae Plants}

Roots of Fagara zanthoxyloides and Pseudocedrela kotchyii showed activity on PC-3, DU145, LNCaP, and CWR-22 cells [137]. LNCap cells were the most sensitive to the two extracts, with the highest inhibition at day 3 and displaying the maximum rate of apoptosis. $\mathrm{IC}_{50}$ values of 5 -day cultures showed that Pseudocedrela extract had a lower $\mathrm{IC}_{50}$ for PC-3, DU145 and LNCap cells $(12-20 \mu \mathrm{g} / \mathrm{mL})$, indicating that these cells were more sensitive to the extract than to the Fagara extract, which had significantly higher $\mathrm{IC}_{50}(25-44 \mu \mathrm{g} / \mathrm{mL})$ supporting the existence of a potential source of chemopreventive agents for prostate cancer therapy [137]. Paramignya trimera (Xao tam phan) has been applied in cancer therapies and cancer-like aliments. Xao tam phan leaf methanol extract (PTL) contains gallic acid, rutin, ellagic acid, protocatechuic acid, and quercetin which has shown to have a pronounced anti-proliferative activity on cancer cell lines including DU145 (growth inhibition of 100\% at $100 \mu \mathrm{g} / \mathrm{mL}$; $\mathrm{IC}_{50}=52 \mu \mathrm{g} / \mathrm{mL}$ ) [153]. The Zanthoxyli fructus water extract demonstrated to have anti-tumor activity against prostate cancer cells LNCaP, DU145, and PC-3. Notably, Z. fructus reduced the proliferation of LNCaP and DU145 cells in xenografts in BALB/c nude mice without adverse effects. Additional studies on LNCaP cells exposed that $Z$. fructus blocked AR signaling in conjunction with down-regulation of nuclear levels of AR and decreased the level of the AR-target molecule. It also stimulated apoptosis, prostate-specific antigen, inhibited AKT kinase and down-regulated levels of cyclin D1 protein [173].

\subsubsection{Solanaceae Plants}

Capsicum chinense plant has indicated the cytotoxic effect on LNCaP with percent inhibition greater than $50 \%$ at $25 \mu \mathrm{g} / \mathrm{mL}$ [123]. WCE caused elevation of malonyldialdehyde levels, suppression of total antioxidant capacity levels, and increased proliferating cell nuclear antigen expression in the prostate gland in testosterone-induced $\mathrm{BPH}$ in rats [171].

\subsubsection{Zingiberaceae Plants}

The aqueous, ethanol and methanol extracts of turmeric (Curcuma longa) presented an antiproliferative effect on PC-3 cells with respectively $34 \%, 55 \%$, and $60 \%$ inhibition [134]. Zingiber officinale (ginger), whole extract (GE) has a high growth-inhibitory and death-inductory effects in a wide-spectrum of prostate cancer cells $\left(\mathrm{IC}_{50}=75-512 \mu \mathrm{g} / \mathrm{mL}\right)$, by impairing reproductive capacity, cell-cycle progression, mitochondrially mediated apoptosis, modulating cell-cycle/apoptosis regulatory molecules. Indeed, daily intake GE $(100 \mathrm{mg} / \mathrm{kg})$ repressed about $56 \%$ the growth and progression of PC-3 xenografts in nude mice, cut proliferation index and widespread apoptosis matched with controls [174]. Besides, GE combination with its major constituents mainly, 6-gingerol) significantly enhances the antiproliferative effect of GE [175].

\subsubsection{Other Plants}

The major secondary metabolites of dried stigmas of Crocus sativus (saffron) comprise safranal, crocin, and picrocrocin [176]. Saffron has medicinal activities such as apoptosis, suppressing the expression of matrix metalloproteinase, stopping cell cycle progression, modulatory effects on some phase II detoxifying enzymes, and decreasing expression of inflammatory molecules [176]. Saffron extract (SE) showed dose and time-dependent antiproliferative effect on 5 different malignant prostate cancer cell lines $\left(\mathrm{IC}_{50}=0.4-4 \mathrm{mg} / \mathrm{mL}\right.$ ), by arresting cells at $\mathrm{G0} / \mathrm{G} 1$ phase and caused apoptosis through strikingly downregulation of Bcl-2 expression, activation of caspase-9 [132]. Xenografted in male nude mice induced with two aggressive prostate cancer cell lines (PC-3 and 22rv1) treated by oral gavage with SE confirmed the in vitro antitumor effects with the mass tumor reduction of $18 \%$ in the PC-3 [133]. Haplophyllum perforatum and Urtica dioica ethanol extract showed antiproliferative activity $\left(\mathrm{IC}_{50}=226 \mu \mathrm{g} / \mathrm{mL}\right.$ on PC-3 cells; $\mathrm{IC}_{50}=37 \mu \mathrm{g} / \mathrm{mL}$ on DU145 cells) [111]. Similarly, Byrsonima crassifolia plant revealed anti-proliferative activity on $\mathrm{LNCaP}$ with more than $50 \%$ inhibition percentage at $25 \mu \mathrm{g} / \mathrm{mL}$ [123]. Nigella sativa contains a wide range of chemical compounds including thymoquinone 
(up to $50 \%$ ), pinene (up to $15 \%$ ), p-cymene (40\%), thymohydroquinone, thymol, and dithymoquinone. The molecular mechanisms behind its anticancer activity comprise cell cycle arrest, apoptosis pathways, ROS generation, anti-metastasis/anti-angiogenesis effects, and apoptosis induction, [150].

Several spices have been used to prevent and to treat prostate cancer, including Allium sativum (garlic), N. sativa (black cumin), and Piper nigrum (black pepper). These plants contain numerous essential bioactive compounds, such as thymoquinone, and piperine, which induce apoptosis, inhibit proliferation, migration, and invasion of tumors, and sensitize tumors to radiotherapy and chemotherapy [131].

Polysaccharides from Psidium guajava (guava) seed, Fagopyrum tataricum (bitter buckwheat), Fagopyrum esculentum (common buckwheat), red Formosa lambsquarters, and yellow F. lambsquarters indirectly significantly inhibit PC-3 cell growth by immunotherapy with splenocyte- and macrophage-conditioned media (SCM or MCM) presenting a negative link between PC-3 cell viabilities and IL- 6 + TNF- $\alpha$ )/IL-10 level ratios in MCM proposing that macrophages suppress PC-3 cell growth through diminishing secretion ratios of proinflammatory/anti-inflammatory cytokines in a tumor microenvironment [138]. The aqueous extract of P. guajava (PE) budding leaves exhibited cytotoxicity with the $\mathrm{IC}_{50}$ of $\sim 0.57 \mathrm{mg} / \mathrm{mL}$ on DU145 cells and effectively hindered the expressions of VEGF, IL-6 and IL- 8 cytokines, and MMP-2 and MMP-9, and simultaneously activated TIMP-2 and suppressed the cell migration and the angiogenesis [157]. At $1.0 \mathrm{mg} / \mathrm{mL}$, PE reduced the viability of DU145 cells to 36.1 and $3.59 \%$, respectively, after $48 \mathrm{~h}$ and $72 \mathrm{~h}$ and lowered the colony forming capability of DU145 cells [177]. This antiproliferative activity was conserved either in the presence or the absence of synthetic androgen R1881 in LNCaP cell and arrest cell cycle at $G(0) / G(1)$ phase with a high quantity of apoptotic LNCaP cells. The treatment with PE considerably reduced both the PSA serum levels and tumor size in a xenograft mouse tumor model [158].

The anticancer potential of Aloe perryi flowers showed the percentage inhibition of various extracts (viz. petroleum ether, chloroform, ethyl acetate, butanol and aqueous) on PC-3 of $88.9 \%$ for petroleum ether extract [114]. Urtica dioica extract expressively repressed the cell growth with $24 \mathrm{~h}$ and $48 \mathrm{~h}\left(\mathrm{IC}_{50}=29.46\right.$ and $15.54 \mu \mathrm{g} / \mathrm{mL}$, respectively), being able to induce apoptosis in PC-3 cells by substantially increasing the caspase- 3 and 9 mRNA expression, while decreasing Bcl-2, and arrested the cell cycle in G2 stage [167]. Extracts from leaves and stems of Chenopodium hybridum containing mainly rutin $(2.80 \mu \mathrm{g} / \mathrm{g}$ dry weight), 3-kaempferol rutinoside $(2.91 \mu \mathrm{g} / \mathrm{g}), 4-\mathrm{OH}$-benzoic $(1.86 \mu \mathrm{g} / \mathrm{g})$ and syringic acids $(2.31 \mu \mathrm{g} / \mathrm{g})$ showed a low cytotoxic activity except for the extract from the leaves, which was effective against prostate Du145 cell line with 98.28\% dead cells at $100 \mu \mathrm{g} / \mathrm{mL}$ [127].

Pomegranate (Punica granatum) fruit as well as its juice, extract, and oil have anti-proliferative, and anti-tumorigenic properties by modulating multiple signaling pathways, suggesting its use as a promising chemopreventive/chemotherapeutic agent of prostate cancer [5]. A peel extract of pomegranate fruit exhibited antiproliferative properties on PC-3 cells, reducing the cell viability to values below $40 \%\left(\mathrm{IC}_{50}<5 \mu \mathrm{g} / \mathrm{mL}\right)$ and maximum mean growth inhibition of $79.3 \%$ [178]. Pomegranate seed methanolic extract reduced the cell viability to values below $23 \%$, even at the lowest doses, and a maximum means growth inhibition of $81.4 \%$ in the same cells [161]. Albrecht et al. [159] demonstrated significant antitumor activity of pomegranate cold-pressed (oil) or supercritical $\mathrm{CO}_{2}$-extracted (S) seed oil, fermented juice polyphenols (W), and pericarp polyphenols (P) on LNCaP, PC-3, and DU145 human prostate cancer cells $\left(\mathrm{IC}_{50}=70 \mu \mathrm{g} / \mathrm{mL}\right.$ ), whereas normal prostate epithelial cells (hPrEC) were expressively less affected $\left(\mathrm{IC}_{50}=250 \mathrm{~g} / \mathrm{mL}\right.$ ). Modifications in both cell cycle distribution and induction of apoptosis were noted. All extracts potently suppressed PC-3 invasion through Matrigel, and furthermore, P and S demonstrated potent inhibition of PC-3 xenograft growth in athymic mice [159].

Polysaccharide extracted from Polygonatum spp. selectively restrained the growth of prostate-cancer-associated broblasts (CAFs) by stimulating autophagy in prostate-CAFs via the activation of Beclin-1 and LC3 (key autophagy proteins) and thus developing the effectiveness of cancer therapy [156]. Costus pulverulentus ethanol extract of the stem (campesterol, stigmasterol $\beta$-sitosterol, vanillic acid, among other components) presented moderate cytotoxic effects on PC-3 
cells $\left(\mathrm{IC}_{50}=179 \mu \mathrm{g} / \mathrm{mL}\right)$ and induced DNA damage in the comet assay at $200 \mu \mathrm{g} / \mathrm{mL}$ or higher concentrations [129]. The study of Ficus deltoidea var. angustifolia (FD1) and var. deltoidea (FD2) including crude methanolic extracts, $n$-hexane (FD1h, FD2h), chloroform (FD1c, FD2c) and aqueous extracts (FD1a, FD2a) fractions on prostate cancer cells revealed that FD1c and FD2c are the most cytotoxic extracts against both prostate cancer cell lines $\left(\mathrm{IC}_{50}=23\right.$ and $29 \mu \mathrm{g} / \mathrm{mL}$, respectively, for PC-3 and 19 and $23 \mu \mathrm{g} / \mathrm{mL}$, respectively, for LNCaP). This occurs through induction of cell death via apoptosis as supported by nuclear DNA fragmentation and increased metalloproteinase depolarization, activation of caspase-3 and -7, and inhibited both migration and invasion of PC-3 cells and down-regulated Bcl-2, VEGF-A and CXCL-12 gene expressions, while that of Bax and Smac/DIABLO were up-regulated. The LC-MS dereplication identified isovitexin in FD1c; and oleanolic acid, moretenol, betulin, lupenone, and lupeol in FD2c [139].

Zhang et al. [152] explored whether total glucosides of paeony, extracted from the root of Paeonia lactiflora, suppressed lipopolysaccharide (LPS)-stimulated proliferation, migration, and invasion in androgen-insensitive prostate cancer cells. At $312.5 \mu \mathrm{g} / \mathrm{mL}$, these compounds suppressed LPS-stimulated proliferation of PC-3 cells, inhibited activation of NF- $\kappa B$ and mitogen-activated protein kinase p38 in LPS-stimulated PC-3 cells and inhibited inflammation-associated STAT3 activation and proliferation, migration and invasion in PC-3 androgen-insensitive prostate cancer cells [152]. Melissa officinalis hydroalcoholic extract presented a high potency to inhibit proliferation of prostate cancer cells in a dose-independent manner with the mean growth inhibition of $79.9 \%$ (maximum growth inhibition of $83.7 \%$ at a dose of $500 \mu \mathrm{g} / \mathrm{mL}$, minimum growth inhibition of $76.29 \%$ at $20 \mu \mathrm{g} / \mathrm{mL}$, respectively. and $\mathrm{IC}_{50}<500 \mu \mathrm{g} / \mathrm{mL}$ on PC-3 cells) [147], by inhibiting the expression of p53, Bcl-2, Her2, VEGF-A and hTERT in human prostate cancer cell lines [146].

Carica papaya (papaya) leaf juice (LJP) extract revealed selective anti-proliferative and anti-metastatic effect against cell lines representing benign hyperplasia, tumorigenic and normal cells of prostate origin prostatic diseases, including prostate cancer. LJP displayed potent antiproliferative effects after $72 \mathrm{~h}$ treatment on RWPE-1, BPH-1, PC-3 and LNCaP cells $\left(\mathrm{IC}_{50}=220,790,950\right.$ and $960 \mu \mathrm{g} / \mathrm{mL}$, respectively). Comparable to LJP, in vitro digested LJP also showed an antiproliferative effect after $72 \mathrm{~h}\left(\mathrm{IC}_{50}=1460,1320,2270\right.$ and $4240 \mu \mathrm{g} / \mathrm{mL}$ on RWPE-1, BPH-1, PC-3, and LNCaP cells, respectively). The medium polar fraction of LJP showed broad-spectrum efficacy (similar to paclitaxel) and selective anti-proliferative activity $\left(\mathrm{IC}_{50}=20-70 \mu \mathrm{g} / \mathrm{mL}\right.$ ) against cells with several phases of prostatic diseases, induced cell cycle arrest at $\mathrm{S}$ phase and apoptosis, and notably inhibited migration and adhesion of PC-3 cells [125]. Likewise, A. wallichii (aqueous ethanol extract) containing flavonoids, steroids, terpenoids, reducing sugars and glycosides exhibited antiproliferative activity on the PC-3 cell line $\left(\mathrm{IC}_{50}=69.69 \mu \mathrm{g} / \mathrm{mL}\right)[113]$.

Hypoxia enhances cancer development in solid tumors. HIF- $1 \alpha$ is a transcription factor, expressed under hypoxia in solid tumor cells, that regulates several target genes. It is involved in cancer progression, including angiogenesis, metastasis, anti-apoptosis, cell proliferation and is related to resistance to cancer treatment [130]. Crataegus Pinnatifida Schneider ethanol extract decreased cell growth, HIF- $1 \alpha$ and sphingosine kinase- 1 (SPHK-1) in hypoxia-induced human prostate cancer DU145 cells [130].

C4-2 prostate cancer cell treatment with muscadine grape skin extract (MSKE) from muscadine grape (Vitis rotundifolia) which is a common red grape used to produce red wine, indicated that this extract could unfold protein response that can eventually lead to apoptosis in prostate cancer cells [168]. The saponin fraction isolated from Lysimachia ciliata (CIL-1/2) exposed no cytotoxic or cytostatic effect at the concentration of $0.5 \mu \mathrm{g} / \mathrm{mL}$ prostate cancer cell lines (DU145, PC-3). In contrast, cocktails of CIL-1/2 and mitoxantrone (a drug commonly used in prostate cancer therapy) displayed synergistic cytostatic and proapoptotic effects on prostate cancer cell movement and invasiveness [144]. Besides, the hydroalcoholic extract of Cornus mas fruit reduced PC-3 cell viability below $26 \%$, even at the lowest doses, with a mean growth inhibition of $81.6 \%$ [128]. 
A Leucas aspera nanoformulation showed a concentration- and time-dependent in vitro cytotoxicity on PC-3 cells that was confirmed by the in vitro hemolysis assay, cellular uptake studies, cell aggregation studies, and cell migration assays [179]. Moringa oleiferna inhibited the cell proliferation of PC-3 cell lines in a concentration-dependent manner $\left(\mathrm{IC}_{50}=14.3\right.$ and $\left.22.2 \mu \mathrm{g} / \mathrm{mL}\right)$ [110]. Silver nanoparticles (AgNps) of Guiera senegalensis leaves extract presented antiproliferation effect on PC-3 cell lines in a concentration-dependent manner $\left(\mathrm{IC}_{50}=23.48 \mu \mathrm{g} / \mathrm{mL}\right)$, indicating its potential applications in pharmacology for the treatment of cancers [180]. Similarly, AgNps from the aqueous extract of $H$. thebaica fruit inhibited the proliferation of prostate cancer cell lines in a dose dependent manner $\left(\mathrm{IC}_{50}=2.6 \mathrm{mg} / \mathrm{mL}\right)$ [181]. The methanol extract of Maytenus royleana $(\mathrm{MEM})$ leaves and its fractions showed to possess antiproliferative effect on prostate cancer cells. The effect was supplemented by G2 phase arrest of cell cycle, increase in cdk inhibitors and downregulation of cyclin/cdk network. MEM treated cells showed cleavage of caspase-3 and PARP, and modulation of apoptotic proteins, determining apoptosis as the primary mechanism of cell death. Remarkably MEM suppressed AR/PSA signaling both in prostate cancer cell cultures and in the in vivo model. Intraperitoneal injection of MEM (1.25 and $2.5 \mathrm{mg} / \mathrm{animal})$ to athymic nude mice implanted with androgen-sensitive CWR22Rv1 cells presented major inhibition in tumor growth and decreased serum PSA levels [145]. Remotiflori radix ethanol extract (ERR) at $>100 \mu \mathrm{g} / \mathrm{mL}$ caused dose- and time-dependent cell death in PC-3 and DU145 cell lines (autophagic and apoptotic effects, induction of LC3 punctuation, YO-PRO-1 uptake, DNA fragmentation, activation of caspases, and PARP cleavage). Phosphorylation of AMPK, ULK, and p38 was increased after ERR treatment, and CHOP (ER stress marker) was also raised. Additionally, oral administration of ERR at $50 \mathrm{mg} / \mathrm{kg}$ efficiently repressed the tumorigenic growth of PC-3 cells with no adverse effects [163].

Berberis libanotica Ehrenb (BLE) is a plant rich in alkaloids with high potential for eliminating advanced prostate cancer cells involved in tumor resistance toward conventional tumor therapy. B. libanotica indicated a dose- and time-dependent manner cytotoxicity and cell death mainly at high concentrations (60 and $100 \mathrm{mg} / \mathrm{mL}$ ) of DU145, PC-3 and 22Rv1 cells, by perturbating the cell cycle, leading to a G0-G1 arrest, Ros production, and also inhibited cell migration and invasion, suggesting a role in inhibiting metastasis [122]. The oral administration of AGN root ethanol extract showed chemopreventive effects against the growth of prostate epithelium and neuroendocrine carcinomas (NE-Ca) in the TRAMP model [116]. Eurycoma longifolia standardized total quassinoids composition (SQ40) with $40 \%$ of total quassinoids repressed LNCaP cell growth and RWPE-1 human prostate normal cells $\left(\mathrm{IC}_{50}=5.97\right.$ and $59.26 \mu \mathrm{g} / \mathrm{mL}$, respectively). SQ40 also inhibited $5 \alpha$-dihydrotestosterone-stimulated growth in LNCaP cells dose-dependently, anchorage-independent growth, suppressed LNCaP cell growth via G0/G1 phase arrest, down-regulated CDK4, CDK2, Cyclin D1, and Cyclin D3, and up-regulated p21Waf1/Cip1 protein levels. At higher concentrations or longer treatment duration, SQ40 can lead to G2M growth arrest and apoptotic cell death (PARP cleavage) in LNCaP cells. Additionally, SQ40 can also inhibit AR translocation to nucleus which is critical for the transactivation of its target gene, PSA, resulting in a substantial decrease of PSA secretion after the treatment. Finally, intraperitoneal injection of 5 and $10 \mathrm{mg} / \mathrm{kg}$ of SQ40 showed to considerably suppress the LNCaP tumor growth on mouse xenograft model [136].

\subsection{Plant-Derived Bioactives with Anti-Prostate Cancer Potential}

Many classes of metabolites isolated from medicinal plants have been reported for their activity against prostate cancer, namely alkaloids, phenolic compounds, and terpenoids (Table 4). 
Table 4. Plant derived-compounds with anti-prostate cancer effects.

\begin{tabular}{|c|c|c|c|}
\hline Bioactive Compounds & In Vitro & In Vivo & References \\
\hline \multicolumn{4}{|l|}{ Alkaloids } \\
\hline (-)-Anonaine & + & - & [182] \\
\hline (-)-Caaverine & + & - & [182] \\
\hline (-)-Nuciferine & + & - & [182] \\
\hline 6-Hydroxycrinamine & + & - & [183] \\
\hline 7-Hydroxydehydronuciferine & + & - & [182] \\
\hline Capsaicin & + & - & [184] \\
\hline Crinamine & + & - & [183] \\
\hline Emetine & + & + & {$[185,186]$} \\
\hline Liriodenine & + & - & [182] \\
\hline Lycorine & + & + & {$[183,187]$} \\
\hline Matrine & + & - & [188] \\
\hline Oxymatrine & + & - & [188] \\
\hline Oxysophocarpine & + & - & [188] \\
\hline Schisanspheninal A & + & - & [189] \\
\hline Sophocarpine & + & - & [188] \\
\hline Tetrandrine & + & - & [190] \\
\hline \multicolumn{4}{|l|}{ Carotenoids } \\
\hline Crocetin & + & - & [133] \\
\hline Crocin & + & - & [132] \\
\hline \multicolumn{4}{|l|}{ Fatty acid } \\
\hline (E)-ethyl 8-methylnon-6-enoate & + & - & [123] \\
\hline \multicolumn{4}{|l|}{ Phenolic compounds } \\
\hline$\alpha$-Mangostin & + & + & [191]. \\
\hline$\gamma$-Tocopherol & + & - & [192] \\
\hline$\delta$-Tocotrienol & + & - & [192] \\
\hline (-)-5,7-Difluoroepicatechin-3-O-gallate & + & - & [193] \\
\hline (-)-Epicatechin-3-O-gallate & + & - & [193] \\
\hline 10-Gingerol & + & - & [175] \\
\hline 6-Gingerol & + & - & [175] \\
\hline 6-Prenylnaringenin & + & - & [194] \\
\hline 6-Shogoal & + & - & [175] \\
\hline 7-o-Galloyl catechin & + & - & [195] \\
\hline 8-Gingerol & + & - & [175] \\
\hline 8-Prenylnaringenin & + & - & [194] \\
\hline Afzelin & + & - & [196] \\
\hline Altholactone & + & - & [197] \\
\hline Apigenin & & + & [198] \\
\hline Camptothin B & + & - & [141] \\
\hline Catechin & + & - & [195] \\
\hline Catechin-3-o-gallate & + & - & [195] \\
\hline Chlorogenic acid & + & - & [130] \\
\hline Chrysin & + & - & [199] \\
\hline Cinnamaldehyde & + & - & [200] \\
\hline Cornusiin A & + & - & [141] \\
\hline Cornusiin $\mathrm{H}$ & + & - & [141] \\
\hline Curcumin & + & + & [201-204] \\
\hline Decursin & + & - & [117] \\
\hline Decursinol angelate & + & - & [117] \\
\hline Dehydrozingerone & + & - & [205] \\
\hline Delphinidin & + & + & {$[206,207]$} \\
\hline Ellagic acid & + & + & {$[208,209]$} \\
\hline Eugenol & + & - & {$[200]$} \\
\hline Fisetin & + & + & [210] \\
\hline Flavokawain A & + & + & [211] \\
\hline Flavopiridol & + & + & [212] \\
\hline
\end{tabular}


Table 4. Cont.

\begin{tabular}{|c|c|c|c|}
\hline Bioactive Compounds & In Vitro & In Vivo & References \\
\hline Garcinol & + & + & {$[213,214]$} \\
\hline Ginkgetin & + & + & [215] \\
\hline Hesperetin & + & - & [216] \\
\hline Hirsutenone & + & - & [217] \\
\hline HLBT-100 or HLBT-001 (5,3'-dihydroxy- & + & - & [218] \\
\hline $6,7,8,4^{\prime}$-tetramethoxyflavanone) & + & 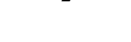 & \\
\hline Honokiol & + & - & [219] \\
\hline Icarisid II & + & - & [220] \\
\hline Isoangustone $\mathrm{A}$ & + & - & {$[221,222]$} \\
\hline Isovitexin & + & - & [139] \\
\hline Juglone & + & - & [223] \\
\hline Licoricidin & + & - & {$[221,222]$} \\
\hline Magnolol & + & - & [224] \\
\hline Mangiferin & + & + & {$[225,226]$} \\
\hline Maysin & + & - & [227] \\
\hline Methyl gallate & + & - & [195] \\
\hline Osthol & + & - & {$[4,228]$} \\
\hline Oxyfadichalcones A & + & - & [229] \\
\hline Oxyfadichalcones B & + & - & [229] \\
\hline Oxyfadichalcones C & + & - & [229] \\
\hline Oxyfadichalcones D & + & - & [229] \\
\hline Oxyfadichalcones E & + & - & [229] \\
\hline Oxyfadichalcones F & + & - & [229] \\
\hline Oxyfadichalcones G & + & - & [229] \\
\hline Paeonol & + & + & [230] \\
\hline Peperotetraphin & + & - & [231] \\
\hline Physangulatins I & + & - & [232] \\
\hline Plumbagin & + & + & {$[155,233]$} \\
\hline Punicalagin & + & - & {$[234]$} \\
\hline Quercetin & + & + & [235-237] \\
\hline Resveratrol & + & + & [238-240] \\
\hline Rutin & + & - & [241] \\
\hline Tannic acid & + & - & [242] \\
\hline Tricin & + & - & [243] \\
\hline Xanthohumol & + & - & {$[188,244]$} \\
\hline \multicolumn{4}{|l|}{ Protein } \\
\hline Agglutinin & + & + & [245] \\
\hline Diffusa cyclotide 1 & + & - & [246] \\
\hline Diffusa cyclotide 2 & + & - & [246] \\
\hline Diffusa cyclotide 3 & + & + & [246] \\
\hline Lectin ConBr & + & - & [247] \\
\hline Lectin ConM & + & - & [247] \\
\hline Lectin DLasiL & + & - & [247] \\
\hline Lectin DSclerL & + & - & [247] \\
\hline \multicolumn{4}{|l|}{ Terpenoids } \\
\hline$\alpha$-Santalol & + & + & [248] \\
\hline $4 S, 5 R, 9 S, 10 R$-Labdatrien-6,19-olide & + & - & [249] \\
\hline $\begin{array}{l}\text { (20R)-Dammarane-3 } \beta, 12 \beta, 20,25 \text {-tetrol } \\
\text { (25-OH-PPD) }\end{array}$ & + & + & [250] \\
\hline Andrographolide & + & + & [251] \\
\hline Celastrol & + & + & [252] \\
\hline Citral & + & - & [135] \\
\hline Diosgenin & + & - & [253]. \\
\hline Euphol & + & - & [254] \\
\hline Isocuparenal & + & - & [189] \\
\hline Jungermannenone A & + & - & [255] \\
\hline Jungermannenone B & + & - & [255] \\
\hline Muricins M & + & - & [256] \\
\hline
\end{tabular}


Table 4. Cont

\begin{tabular}{lccc}
\hline \multicolumn{1}{c}{ Bioactive Compounds } & In Vitro & In Vivo & References \\
\hline Muricins N & + & - & {$[256]$} \\
Nummularic acid & + & - & {$[257]$} \\
Oenotheralanosterol B & + & - & {$[258]$} \\
Plectranthoic acid & + & - & {$[259]$} \\
Sutherlandioside D & + & - & {$[166]$.} \\
Widdaranal A & & - & {$[189]$} \\
Widdaranal B & + & - & {$[189]$} \\
Widdarol peroxide & + & - & {$[189]$} \\
Withaferin A & + & - & {$[260]$} \\
\hline
\end{tabular}

-, no effect observed; + , positive effect.

\subsubsection{Alkaloids}

6-Hydroxycrinamine, lycorine, and crinamine three alkaloids from Crinum asiaticum showed potent hedgehog $(\mathrm{Hh}) / \mathrm{GLI} 1-m e d i a t e d$ transcriptional inhibitory activity $\left(\mathrm{IC}_{50}=14.3,19.4\right.$, and $4.7 \mu \mathrm{M}$, respectively) and revealed cytotoxicity against DU145 cells both PANC1 cells $\left(\mathrm{IC}_{50}=22.7,19.9\right.$, and $10.0 \mu \mathrm{M}$, respectively) and DU145 cells $\left(\mathrm{IC}_{50}=9.3,21.7\right.$, and $18.5 \mu \mathrm{M}$, respectively), without affecting normal cell lines. These compounds repressed the Hh signaling pathway by down-regulating the expression of GLI-related proteins (PTCH and BCL2) in DU145 cells [183]. Likewise, liriodenine, (-)-anonaine, (-)-caaverine, (-)-nuciferine, 7-hydroxydehydronuciferine from the leaves of Nelumbo nucifera Gaertn. cv. rosa-plena have shown significant cytotoxicity in DU145 cells $\left(\mathrm{IC}_{50}=95.4,150.1\right.$, 94.4, 218.4, and $80.8 \mu \mathrm{M}$, respectively) [182]. Capsaicin, the spicy ingredient of red hot chili peppers, has been shown to induce death in LNCaP and PC-3 in a time- and concentration-dependent manner by increasing the levels of microtubule-associated protein light chain 3-II (a marker of autophagy) and the accumulation of the cargo protein p62, indicating an autophagy blockage and triggered ROS generation in cells [184]. Emetine, a naturally-derived alkaloid from the Carapichea ipecacuanha plant, has been shown to have the potential for anti-tumorigenic effects for cancer treatments. Novel emetine dithiocarbamate (EMTDTC) analogs EMTDTC-55 and EMTDTC-56 shown important anti-tumorigenic activities on DU145, LNCaP and PC-3 and apoptotic potential effect in the prostate cancer cells. These compounds have also shown major chemotherapeutic potential in moderately metastatic DU145 and highly metastatic PC-3 cells [185]. Lycorine (an alkaloid extracted from Amaryllidaceae family plants) has been reported to inhibit proliferation, induced cell apoptosis, and cell death in various prostate cancer cell lines. It has also withdrawn both growth and metastasis in multiple organs in in vivo assays and improved mice survival in subcutaneous and orthotopic xenotransplantations, by ectopic implantation of the human hormone-refractory PC-3M-luc cells. Additionally, lycorine showed to block EGF-induced JAK/STAT signaling and induce STAT expression [187]. Sophocarpine, matrine, oxymatrine, and oxysophocarpine from radix Sophorae flavescentis, a plant used for the treatment of different stages of prostate cancer in China, has demonstrated antiproliferative and apoptosis activity. Specifically, matrine had good inhibitory effects, with half maximal inhibitory concentration values of $0.893 \mathrm{mg} / \mathrm{mL}$ [188]. Schisanspheninal A from the hexane extract of fruits of Schisandra grandiflora revealed anti-proliferative activity against DU145 $\left(\mathrm{IC}_{50}=165 \mu \mathrm{M}\right)$ [189]. Tetrandrine, isolated from traditional Chinese medicinal plant Stephania tetrandra, has also reported antiproliferative activities against PC-3 $\left(\mathrm{IC}_{50}=7.68 \mu \mathrm{M}\right)[190]$.

\subsubsection{Phenolic Compounds}

\section{Flavonoids}

Treatment of low-metastatic LNCaP and high-metastatic PC-3 cells with green tea polyphenols (-)-epicatechin-3-O-gallate and (-)-5,7-difluoro-epicatechin-3-O-gallate confirmed a dose-dependent 
inhibition of cell viability. The effects propose that (-)-epicatechin-3-O-gallate and the more effective (-)-5,7-difluoroepicatechin-3-O-gallate might be therapeutically used to inhibit tumorigenesis during initiation, promotion, and progression by reducing inflammation [193]. Polyphenolic compounds 7-O-galloyl catechin (GC), catechin (C), methyl gallate (MG), and catechin-3-O-gallate (CG) from Acacia hydaspica caused cell death of PC-3 cell, in a dose-dependent manner via apoptosis. The treatment suppressed the expression of $\mathrm{Bcl}-2, \mathrm{Bcl}-\mathrm{XL}$ and survivin, and down-regulated the signaling pathways of AKT, NF-KB, ERK1/2 and JAK/STAT in the same cells [195]. Licoricidin, which inhibits metastasis and isoangustone $\mathrm{A}$, which induces apoptosis G1 cycle arrest, are two active components found in glycyrrhizin hexane/ethanol extract of G. uralensis. Their activity was related to reduced activation of proteases, and the levels of adhesion molecules may constitute a component of the mechanism [221,222]. Moreover, Hesperetin, a flavonoid found in numerous citrus species, has been reported to have an antiproliferative effect in PC-3 cells and to cause the rise of IL-6 gene expression, IL-6 protein secretion, signal transducer and activator of transcription 3 (pSTAT3), extracellular signal-regulated kinases 1/2 (pERK1/2) and pAKT signaling pathways. Likewise, hesperetin treatment induced cell cycle arrest at the G1 phase and can be considered as an agent to synchronize and stop cell cycle at G0/G1 phase [216].

Over expressed MiR-21 in prostate cancer is associated with metastasis and drug resistance to chemotherapy with DX. 4',5,7-Trihydroxy-3', $5^{\prime}$-dimethoxyflavone (tricin) isolated from Allium atroviolaceum has potentiated the effect of DX on PC-3 cell proliferation $\left(\mathrm{IC}_{50}=117.5 \mu \mathrm{M}\right.$ and $0.1 \mathrm{nM}$ for tricin and DX, respectively). The synergistic effect of the combination of Tricin and DX significantly decreased the proliferation of PC-3 cells. Besides, MiR-21 in treated cells with Tricin pointedly reduced compared with the control, suggesting the aptitude of tricin to efficiently decrease metastasis and drug resistance of DX [243]. A flavonoid of the flavanone class, HLBT-100 (or HLBT-001), isolated from Tillandsia recurvata exhibited potent anti-prostate cancer ( $\mathrm{IC}_{50}$ values $<0.100 \mu \mathrm{M}$ ), affecting the cell cycle, activate caspase-3/7, cause DNA fragmentation culminating in apoptotic cell death. It has also shown antiangiogenic potential by inhibiting capillary sprout and tube formation in a dose-dependent manner in the ex vivo rat aortic ring [218]. Altholactone, another natural flavanone isolated from Goniothalamus spp., has confirmed anticancer activity against DU145 by stimulating cell cycle arrest in S phase and triggered apoptosis, and inhibition of NF-KB and STAT3 activity [197]. In another study, 6-prenylnaringenin and 8-prenylnaringenin, two prenylflavonoids present in Humulus lupulus displayed a dose-dependent reduction of cellular proliferation of PC-3 cells [194]. Isovitexin from Ficus deltoidea has also shown antiproliferative activity against PC-3 cells ( $\mathrm{IC}_{50}=43 \mu \mathrm{g} / \mathrm{mL}$ ) [139].

Apigenin, a naturally occurring plant flavone, has been shown to have anti-proliferative, and anti-carcinogenic activities. Orally administrating apigenin to TRAMP mice (20 and $50 \mu \mathrm{g} / \mathrm{mouse} /$ day, 6 days/week for 20 weeks), resulted in a reduction in tumor volume of the prostate and a stop in metastasis, which was linked with inhibition of NF- $\mathrm{kB}$ activation and binding to the DNA. This flavone led to apoptosis via downregulation of the expression of NF-kB-regulated gene products related to proliferation (cyclin D1, and COX-2), anti-apoptosis (Bcl-2 and Bcl-xL), and angiogenesis (VEGF) and increased cleaved caspase-3 labeling index in the dorsolateral prostate [198]. Another natural flavone found in several plant extracts chrysin, induced death of prostate cancer cells by apoptosis supported by DNA fragmentation and increasing the population of both DU145 and PC-3 death cells in the sub- $\mathrm{G}_{1}$ phase of the cell cycle (inducing mitochondrial-mediated apoptosis and ER stress, and regulating signaling pathways responsible for proliferation of prostate cancer cells) [199]. Maysin isolated from Zea mays corn silks dose-dependently reduced the PC-3 cell viability, with an $87 \%$ reduction at $200 \mu \mathrm{g} / \mathrm{mL}$ via stimulation of mitochondrial-dependent apoptotic cell death as indorsed by DNA fragmentation, depolarization of mitochondrial membrane potential, and reduction in Bcl-2 and pro-caspase-3 expression levels. This compound also significantly diminished the phosphorylation of Akt and ERK. Combined treatment with maysin and other anticancer agents, including 5-FU, etoposide, cisplatin, or camptothecin, synergistically increased PC-3 cell death [227]. A compound obtained from the leaves of G. biloba, ginkgetin, has demonstrated to inhibit both inducible and constitutively activated STAT3 and to block the nuclear translocation of p-STAT3 in DU145 prostate 
cancer cells [215]. It has selectively constrained the growth of prostate tumor cells by inducing STAT3 dephosphorylation at Try705 and inhibited its localization to the nucleus, leading to the inhibition of expression of STAT3 target genes such as cell survival-related genes (cyclin D1 and survivin) and anti-apoptotic proteins (Bcl-2 and Bcl-xL) and thereby inhibiting the growth of STAT3-activated tumor cells. The inhibition of tumor growth in xenografted nude mice and downregulated p-STAT3(Tyr705) and survivin in tumor tissues was also reported in this study [215].

Afzelin, a flavonol glycoside that was earlier isolated from Nymphaea odorata inhibited the proliferation of LNCaP and PC-3 cells through inhibition of LIM domain kinase 1 expression and blocked the cell cycle in the $\mathrm{G}_{0}$ phase [196]. Likewise, rutin, another flavonol glycoside isolated from Solanum macaonense releaved to have selective moderate cytotoxicity toward DU145 cancer cell lines $\left(\mathrm{IC}_{50}=31.8 \mu \mathrm{M}\right)$ [241]. A flavonoid glycoside from Epimedium herb extract, icarisid II, indicated a very potent antiproliferative effect on $\mathrm{LNCaP}$ cells at $10 \mu \mathrm{M}$ with less than $25 \%$ of cell viability and suppressed the expression of the androgen-responsive KLK3 gene [220].

Quercetin, a flavonoid compound ubiquitous in numerous dietary plants, possesses evidenced potential in treating advanced metastatic castration-resistant prostate cancer $[235,236]$. Quercetin not only resulted in a rise in the G2/M phase population in both PC-3 and LNCaP cells but also increased the $S$ phase population in PC-3 cells ( $\mathrm{IC}_{50}=22.12 \mu \mathrm{M}$ for PC-3 and $23.29 \mu \mathrm{M}$ for LNCaP cells) [237]. Quercetin and its derivatives anti-proliferative activities towards both androgen-refractory and androgen-sensitive prostate cancer cells signpost that 3,4',7-O-trialkylquercetins were much more potent than quercetin towards prostate cancer cells [235]. Fisetin is a plant flavonoid with therapeutic potential against such as prostate cancer. Metabolomic analysis of tumor xenografts from fisetin-treated animals recognized several metabolic targets with hyaluronan (HA) as the most affected. Fisetin showed to downregulate secreted and intracellular HA levels on both in vitro and in vivo studies model of prostate cancer [210]. Flavopiridol, a flavonoid alkaloid, showed high antiproliferative potential at a very low concentration of $0.1 \mathrm{ng} / \mathrm{mL}$ in three of four prostatic xenografts. Overall, in $61 \%$ tumor xenografts the drug treatment resulted in an IC70 of $<10 \mathrm{ng} / \mathrm{mL}$. Later, in vivo studies corroborated this antitumor activity in prostate cancer xenografts investigated at a maximally tolerated dose (10 mg/kg/day, administered orally), causing tumor regression in PRXF1337 and tumor stasis lasting for 4 weeks in PRXF1369 [212].

Anthocyanidins

Delphinidin is a major anthocyanidin compound found in many fruits that considerably inhibit prostate cancer cells cell growth, but with a different dose response of prostate cancer cells to this drug $\left(\mathrm{IC}_{50}=50,70,65\right.$, and $90 \mu \mathrm{M}$ for LNCaP, C4-2, 22Rv1, and PC-3 cells, respectively, $48 \mathrm{~h}$ post-treatment). Delphinidin treatment prevents the tumorigenic potential of PC-3 cells in in vivo preclinical setting via interference with the NF-кB signaling pathway [207]. This anthocyanidin induces p53-mediated apoptosis by suppressing histone deacetylase activity through increased caspase- $3,-7$, and -8 activity and activating p53 acetylation in LNCaP cells [206].

Phenols

The dehydrozingerone from the rhizome of $Z$. officinale and its derivatives displayed potent cytotoxic potential ( $\mathrm{IC}_{50}=1.8-3.0 \mu \mathrm{M}$ on PC-3 cell lines), and the derivatives have shown to be more potent than the parent compound [205]. Cinnamaldehyde and eugenol are naturally present in cinnamon, bay leaf and eugenol is abundantly present in clove. They both possess $64-75 \%$ cytotoxic activity against PC-3 cell line at $100 \mu \mathrm{M}$ concentration [200]. Garcinol, a polyisoprenylated benzophenone isolated from Garcinia indica fruit rinds of revealed antitumor activity by inducing apoptosis and inhibiting autophagy in human prostate cancer cells at $30 \mu \mathrm{M}$. Also, in vivo assays showed the reduction of the tumor size more than $80 \%$ after the mouse treatment, confirming the in vitro results [213]. Garcinol showed to inhibit several key regulatory pathways (e.g., NF-kB and STAT3) in cancer cells, thus explaining its ability to control the malignant growth of solid tumors 
in vivo [214]. This drug is still in the preclinical stage due to a lack of systematic and conclusive evaluation of pharmacological parameters [214]. A phenol from the root bark of Paeonia moutan and the grass of radix Cynanchi Paniculati, paeonol, has been reported to block growth of prostate cancer cells, DU145 and PC-3 in dose-and time-dependent manner, induce apoptosis and enhance activities of caspase-3, caspase-8, and caspase-9, reduced expression of Bcl-2, and rise expression of Bax, cut phosphorylated status of Akt and mTOR in DU145. Paeonol and PI3K/Akt inhibitor exhibited a synergistic antiproliferative effect on DU145 cells. Furthermore, the oral administration of paeonol to the DU145 tumor-bearing mice considerably lowered tumor cell proliferation and led to tumor regression [230]. Resveratrol, another phenol, has demonstrated to inhibit cell growth induced by androgen R1881 or 17 $\beta$-estradiol in a concentration-dependent manner at concentrations as low as $1 \mu \mathrm{M}$ for androgen and as low as $5 \mu \mathrm{M}$ for $17 \beta$-estradiol. In a xenograft model, resveratrol hindered LNCaP tumor growth and repressed expression of a marker for steroid hormone responses [239]. Amongst tocotrienols, $\delta$-tocotrienol has exhibited the highest anti-cancer activity. The combination of $\delta$-tocotrienol and $\gamma$-tocopherol $(10 \mu \mathrm{M}+5 \mu \mathrm{M}$, respectively) showed synergy in anti-prostate cancer activity against LNCaP by stopping both cell cycles in the G1 and G2/M phases [192]. A phenol glycoside from stems and leaves of Physalis angulata, physangulatins I, indicated antiproliferative effects against human prostate cancer cells ( $\mathrm{IC}_{50}=1.17$ and $2.12 \mu \mathrm{M}$ in C4-2B and 22Rvl cells, respectively), and inhibitory effects on NO production induced by LPS in macrophages $\left(\mathrm{IC}_{50}=3.51 \mu \mathrm{M}\right)$ [232]. Hirsutenone, from Alnus japonica, can directly inhibit of Akt1/2 and suppress anchorage-dependent and independent cell growth, inducing apoptosis in both PC-3 and LNCaP cells, by direct binding in adenosine triphosphate (ATP)-noncompetitive manner. These results have also been showed ex vivo [217]. Additionally, hirsutenone treatment has proven to reduce phosphorylation of mTOR, a downstream substrate of Akt, without disturbing Akt phosphorylation [217].

\section{Lignans}

Magnolol is a lignan found in the roots and bark of Magnolia officinalis (magnolia tree). After a 24-h exposure $(40$ and $80 \mu \mathrm{M})$, presented cytotoxicity with $49-50 \%$ and $50-76 \%$ of inhibition, respectively, affecting cell cycle progression of DU145 and PC-3 cells. This induced shifts in the cell cycle and a reduction in the proportion of cells entering the G2/M-phase. Magnolol repressed the expression of regulatory proteins (e.g., A, B1, D1, E, CDK2, and CDK4 cyclins). While this lignin led to a decrease in retinoblastoma protein $(\mathrm{pRb}) \mathrm{pRBp} 107$, but pRBp130 increased. Protein expression levels of p16(INK4a), p21, and p27 apparently did not change after a $24 \mathrm{~h}$ exposure, however, after exposure at $6 \mathrm{~h}$ did increase p27 protein expression levels, demonstrating that magnolol can modify the performance of androgen-insensitive DU145 and PC-3 cells [224]. A norlignan from Peperomia tetraphylla, peperotetraphin, was reported to inhibit the PC-3 cell growth in a dose- and time-dependent fashion and to induce the cell cycle arrest at the G1-S phase, causing apoptosis [231].

\section{Naphthoquinones}

Plumbagin (5-hydroxy-2-methyl-1,4-naphthoquinone) is a plant-derived naphthoquinone obtained mostly from the families Plumbaginaceae, Droseraceae, and Ebenaceae [261]. Reports have shown that this compound can strongly inhibit the invasion of DU145, PC-3, and CWR22rv1 and induce apoptosis in PC-3, LNCaP, and C4-2 cells ( $5 \mu \mathrm{M}$ and $20 \mu \mathrm{M})$. The intraperitoneal administration of $2 \mathrm{mg} / \mathrm{kg}$ body weight of plumbagin resulted in delayed tumor growth by 3 weeks and reduced both tumor weight and volume by $90 \%$ [233]. A stable nanoformulation of plumbagin nanoparticles from Plumbago zeylanica root extract in vitro cytotoxicity exhibited concentration and time-dependent toxicity on prostate cancer cells. Nonetheless, the drug was described as highly toxic to normal cells (when compared with plumbagin nanoformulation). Plumbagin nanoparticles were found biocompatible, demonstrating antimetastasis and apoptotic activity in prostate cancer $[155,261]$. 
Tannins

Cornusiin A, camptothin B, and cornusiin $\mathrm{H}$ are tannins from the acetone extract of Cornus alba. These compounds have shown selective antiproliferative effects on LNCaP hormone-dependent prostate cancer $\left(\mathrm{IC}_{50}=48.32,41.48,44.06 \mu \mathrm{M}\right.$, respectively) more potently than DU145 cells $\left(\mathrm{IC}_{50}=6.31\right.$, 6.03, $5.97 \mu \mathrm{M}$, respectively), inducing apoptosis and S-phase arrest [141]. Ellagic acid has also proved to have anticancer effects against in LNCaP, PC-3, and DU145 (weaker in these two cells lines), by declining cell proliferation through phosphorylated STAT3, ERK, and AKT cellular signaling proteins reduction [209]. It also induces apoptosis by caspase-3 activation in the in vivo TRAP model, increasing Bax/Bcl-2 ratio, and cut the level of lipid peroxidation in ventral prostate [208]. Punicalagin, another polyphenol from pomegranate, has also displayed potent anticancer activity in prostate cancer, with concentration-dependent selective inhibition of viability in PC-3 and LNCaP at 10-100 $\mu \mathrm{M}$, via stimulation of apoptosis and anti-angiogenic effect [234]. Likewise, tannic acid dependently inhibited the proliferation of PC-3 and $\mathrm{LNCaP}\left(\mathrm{IC}_{50}=35.3 \mu \mathrm{M}\right.$ and $29.1 \mu \mathrm{M}$, respectively). This compound worked by significantly inhibit the migration of prostate cancer cells (92.7\%) and have an anti-invasive potential of PC-3 cells (80.9\%). Tannic acid enlarged early apoptosis rate of PC-3 and LNCaP cells but also regulated protein and mRNA expressions of several enzymes (e.g., CYP17A1, CYP3A4, CYP2B6, NQO1, GSTM1, and GSTP1) [242].

\section{Coumarins}

Decursin is a coumarin from AGN or KMKKT root ethanolic extract, known as an antiandrogen and AR compound that can suppress PSA expression after 48-h exposure on prostate cancer cells $\left(\mathrm{IC}_{50}=0.4 \mu \mathrm{g} / \mathrm{mL}\right)$. Decursin has been reported to repeat the neuroendocrine differentiation induction and G1 arrest actions of AGN or KMKKT to inhibit androgen-stimulated AR translocation to the nucleus and down-regulate the AR protein abundance without affecting the AR mRNA level [262]. In an in vivo study, TRAMP mice gavage-treated daily with excipient vehicle, AGN (5 mg/mouse) or equimolar decursin (D)/isomer decursinol angelate (DA) (D/DA) (3 mg/mouse) suggested that D/DA act as probable active/prodrug compounds against epithelial lesions, and might assist with non-pyranocoumarin molecules to entirely express AGN efficacy against NE-Ca. Mice bearing NE-Ca and treated with AGN-and D/DA showed inhibition in prostate growth. Higher survival of mice was improved by AGN, but not by D/DA, yet AGN-and D/DA-treated mice had lower NE-Ca burden [117]. Lastly, osthol, a natural coumarin isolated from Apiaceous plants has shown protective and therapeutic in PC-3 $\left(\mathrm{IC}_{50}=28.81 \mu \mathrm{M}\right)$ by regulating apoptosis, proliferation and invasion mediated by multiple signal transduction cascades $[4,228]$.

\section{Polyphenols}

It has been reported that Z. officinale polyphenolic components viz., 6G(6-gingerol), 8G(8-gingerol), 10G (10-gingerol), 6S (6-shogoal) are more active than whole ginger extract against prostate cancer cells $\left(\mathrm{IC}_{50}=22.07 \mu \mathrm{g} / \mathrm{mL}\right.$ for $6 \mathrm{G}, 3.22 \mu \mathrm{g} / \mathrm{mL}$ for $8 \mathrm{G}, 17.53 \mu \mathrm{g} / \mathrm{mL}$ for $10 \mathrm{G}, 1.12 \mu \mathrm{g} / \mathrm{mL}$ for $6 \mathrm{~S}$, and $250 \mu \mathrm{g} / \mathrm{mL}$ for ginger extract) [175]. Additionally, chlorogenic acid (CA), a polyphenol from C. pinnatifida was studied for the treatment of DU145 cells for $48 \mathrm{~h}$. The outcome reported a reduction in cancer cell growth, phosphorylation AKT and glycogen synthase kinase-3 $\beta$ (GSK-3 $\beta$ ), which are related with HIF-1 $\alpha$ stabilization and disturbed SPHK-1 in a concentration-dependent manner the secretion and cellular expression of VEGF (preventing hypoxia-induced angiogenesis). This effect was confirmed by a reduction in proliferation of cell nuclear chlorogenic acid antigen [130]. Curcumin (diferuloylmethane), a polyphenol originated from C. longa [201], has been shown to have an antitumor effect in several biological pathways implicated in tumorigenesis, mutagenesis, apoptosis, cell cycle regulation and metastasis [204]. Compared with the parent curcumin, curcumin nanoparticles (nanocurcumin) present noteworthy activity against PC-3 cells and low toxicity against normal cells (HEK) [201]. The in vitro and in vivo efficacy of curcumin in the treatment of prostate cancer, especially for castration-resistant 
prostate cancer, has also been demonstrated [202,203]. Magnolia spp. has a drug, honokiol, which can be isolated from bark and leaves. This biphephonol has proven chemopreventive and/or therapeutic effects against prostate cancers, affecting multiple signaling pathways, molecular and cellular targets (e.g., NF-kB, STAT3, EGF receptor, cell survival signaling, cell cycle, cyclooxygenase, and other inflammatory mediators) [263]. Honokiol showed to be highly effective in dose-and time-dependently inhibit the viability of $\mathrm{LNCaP}$ and C4-2, cutting the protein level of $\mathrm{AR}$, androgen-stimulating nuclear translocation of AR, and transcriptional activity of AR in prostate cancer cells lines [219].

Xanthones

Mangiferin (1,3,6,7-tetrahydroxyxanthone-C2- $\beta$-D-glucoside) is a xanthonoid found in plants, for example, Mangifera indica [226]. In a study, mangiferin has shown to reduce the proliferation of PC-3 cells in a concentration-dependent manner $(20 \mu \mathrm{M}$, for $72 \mathrm{~h}$, or $40 \mu \mathrm{m}$ for 48 or $72 \mathrm{~h})$. This drug led to dose-dependent apoptosis and enhanced the caspase-3 activity in PC-3 cells [225]. A single administration of mangiferin or in combination with recognized anticancer drugs revealed possible benefits. Pharmaceutical development, clinical trials on cancer targets are still lacking [226]. $\alpha$-Mangostin from Garcinia mangostana (mangosteen fruit) has shown biological effects in prostate cancer cells by selectively upregulating ER stress markers and causing apoptosis in 22Rv1 and LNCaP prostate cell lines. In an in vivo assay, this compound has also significantly suppressed tumor growth in mice, without obvious toxicity [191].

Chalcones

Oxyfadichalcones A-G isolated from the aerial parts of Oxytropis chiliophylla were evaluated and revealed cytotoxic activities against the PC-3 cell line (inhibition: 57.9-97.6\%) [229]. Similarly, resveratrol, found in large amounts in the skin of grapes, tomatoes, and in red wine [264] can reduce the proliferation of PC-3 and LNCaP cells (>10-50 $\mu \mathrm{M}$ for $48 \mathrm{~h}$ ) [238]. Humulus lupulus contains xanthohumol, a prenylated chalcone, which has been tested on LNCaP in combination with TRAIL. The drug has demonstrated antiproliferative effect mediated by apoptosis via activation of caspases-3, $-8,-9$, Bid, rising expression of Bax, and reducing expression of $\mathrm{Bcl}-\mathrm{XL}$ and mitochondrial membrane potential [244]. Li et al. [211] revealed that flavokawain A (FKA), a chalcone from Piper methysticum (kava), selectively constrained the growth of $\mathrm{pRb}$ deficient cell lines, resulting in a proteasome-dependent, and ubiquitination-mediated Skp2 degradation. Finally, dietary feeding TRAMP mice with FKA led to clear anti-proliferative and apoptotic effects via down-regulation of Skp2 and NEDD8 and up-regulation of p27/Kip1 in the mice's prostate [211].

\section{Carotenoids}

Crocin, $C$. sativus major constituent, has revealed antiproliferative effects $\left(\mathrm{IC}_{50}=0.26-0.95 \mathrm{mM} / \mathrm{mL}\right)$ on prostate cancer cells by arresting cell cycle progression and inducing apoptosis in prostate cancer [132]. Both crocin and crocetin reduced tumor growth in PC-3 and 22rv1 xenografts [133], however, crocetin exhibited superior antitumor effects when compared with crocin and SE with the mass tumor reductions of $38 \%$, and $75 \%$, respectively, in PC-3 xenografts. Both treatments regressed the epithelial-mesenchymal transdifferentiation and repressed prostate cancer cell invasion and migration via downmodulation of metalloproteinase and urokinase expression/activity, which suggests that these drugs may affect metastatic processes [133].

\subsubsection{Terpenoids}

Sesquiterpenes

A sesquiterpene isolated from Santalum spp. (sandalwood), $\alpha$-santalol, has demonstrated anticancer effects, inducing cell-cycle arrest and apoptosis in both in vitro and in vivo models of prostate cancer [248]. Likewise, sesquiterpenes viz. widdarol-peroxide, widdaranal A, widdaranal B 
and isocuparenal from the hexane extract of Schisandra grandiflora fruits, indicate anti-proliferative activity against prostate cancer cells DU145 $\left(\mathrm{IC}_{50}=114.2,151.8,191.1\right.$, and $\left.260.3 \mu \mathrm{M}\right)$ [189].

\section{Diterpenoids}

The $n$-hexane extract of Salvia leriifolia contains the compound $4 S, 5 R, 9 S, 10 R$-labdatrien-6,19-olide that has been reported to have an antiproliferative effect against DU145 cells $\left(\mathrm{IC}_{50}=50 \mu \mathrm{M}\right)$ [249]. Moreover, andrographolide, a diterpenoid from Andrographis paniculata has inhibited tumor growth in a mouse xenograft model with castration-resistant DU145 cells, reduced cell viability and led to apoptosis of PC-3 and DU145 cell lines [251]. The Chinese liverwort Jungermannia fauriana contains the ent-kaurane diterpenoids, jungermannenone $\mathrm{A}$ and $\mathrm{B}(\mathrm{JA}, \mathrm{JB})$. These drugs have shown antiproliferation activities in PC-3 cells $\left(\mathrm{IC}_{50}=1.34\right.$ and $4.93 \mu \mathrm{M}$, respectively), leading to cell apoptosis, DNA damage, mitochondrial damage, downregulated DNA repair proteins Ku70/Ku80 and RDA5, and ROS accumulation in PC-3 cells. Specifically, JA provoked marked cell cycle arrest at the G0/G1 phase (linked to c-Myc suppression), and JB forced the cell cycle block in the G2/M phase (linked to the activation of JNK signaling) [255].

\section{Triterpenoids}

Celastrol, an active component of Tripterygium wilfordii roots, notably reduced migration and proliferation of PC-3 cells, tissues invasion (VEGF secretion) in a dose-dependent manner. The pre-treatment of celastrol in a mouse model $(8 \mu \mathrm{M}$, intratibial injection) was shown to prevent prostate cancer bone metastasis [252]. Furthermore, citral from C. citratus presents anticancer activity in LNCaP and PC-3 cell lines and demonstrating to be an interesting molecule for the treatment of prostate cancer $\left(\mathrm{IC}_{50}=4.3 \mu \mathrm{g} / \mathrm{mL}\right.$ and $14.3 \mu \mathrm{g} / \mathrm{mL}$ ) [135]. Euphol (a tetracyclic triterpene alcohol), the main constituent of Euphorbia tirucalli, a subtropical and tropical plant, displays cytotoxic effects against prostate cancer cell lines $\left(\mathrm{IC}_{50}=1.41-38.89 \mu \mathrm{M}\right)$ [254]. Withaferin $\mathrm{A}(\mathrm{WA})$, a natural compound derived from the medicinal plant Withania somnifera, inhibited PC-3 cell lines growth at $1.2 \mu \mathrm{M}$. WA induced apoptosis via activation of caspase-8, -9 and -3 , cleavage of PARP, obstructing the translocation of NF- $\mathrm{KB}$ and down-regulation of anti-apoptotic proteins (inhibitor of apoptosis protein - cIAP1/2, and the X-linked inhibitor of apoptosis protein) [260]. The main chemical constituent of Fraxinus xanthoxyloides, nummularic acid, expresses a time and dose-dependent reduction of the proliferation and colony formation capabilities of DU145 and C4-2 cells at concentrations of 5-60 $\mu \mathrm{M}$. Nummularic acid diminished the migratory and invasive properties, amplified apoptosis, and activated 5' AMP-activated kinase (AMPK) [257]. Oenotheralanosterol B and a mixture of oenotheralanosterol A and oenotheralanosterol B from Oenothera biennis, exhibited antiproliferative activity against prostate cancer cell lines $\left(\mathrm{IC}_{50}=8.35-49.69 \mu \mathrm{g} / \mathrm{mL}\right)$ [258]. At the concentration of $10 \mu \mathrm{g} / \mathrm{mL}$, sutherlandioside D isolated from $S$. frutescens showed to restrain the Gli-reporter activity (Gli/Hh signaling) by $89 \%$ in prostate cancer cells [166]. Plectranthoic acid from Ficus microcarpa indicated AMPK activating properties far superior to those of metformin. Treatment of prostate cancer cells with this compound repressed proliferation and induced G0/G1 phase cell cycle arrest. Its activity was related with up-regulation of cyclin kinase inhibitors p21/CIP1 and p27/KIP1, suppressing mTOR/S6K signaling and inducing apoptosis, and autophagy (this later effect was found independent of AMPK activation) [259]. (20R)-Dammarane-3 $\beta, 12 \beta, 20,25$-tetrol (25-OH-PPD), is a ginsenoside or triterpenoid saponin isolated from Panax ginseng. Is a study, this drug showed anticancer activities in LNCaP and PC-3 cells (concentrations of 50 and $100 \mathrm{mM}$ ), by apoptosis and cell cycle arrest at G1 phase. 25-OH-PPD potently inhibit in vivo tumor growth. Moreover, a co-administration of 25-OH-PPD with taxotere, led to a $28 \%$ in tumor growth inhibition (when compared with taxotere alone), causing almost a whole inhibition of the tumor growth [250].

\subsubsection{Steroids}

Diosgenin, a steroid compound from Dioscorea nipponica, shows the ability to inhibit the proliferation of DU145 cells with ( $\mathrm{IC}_{50}$ of $6.76 \mu \mathrm{g} / \mathrm{mL}$ at $48 \mathrm{~h}$ ) by activating apoptosis and autophagy 
(correlated with the inhibition of the PI3K/Akt/mTOR signaling pathway) [253]. Also, muricins $\mathrm{M}$ and $\mathrm{N}$ from of the fruit powder of Graviola (Annona muricate) have been validated for its strong anti-proliferative activities against PC-3 cells $(20 \mu \mathrm{g} / \mathrm{mL}$ by $60 \%$; full PC-3 cells for $24 \mathrm{~h}$; $80 \%$ full PC-3 cells for $47 \mathrm{~h}$ for muricin M) [256].

\subsubsection{Proteins}

Diffusa cyclotides 1 to 3 (DC1-3), are peptides from Hedyotis diffusa (leaves and root). These compounds have showed potent cytotoxicity against LNCaP ( IC $_{50} 0.21-5.03 \mu \mathrm{M}$ ), PC-3 ( $\mathrm{IC}_{50}$ 0.76-2.24 $\left.\mu \mathrm{M}\right)$, DU145 ( $\mathrm{IC}_{50}$ 0.55-3.32 $\left.\mu \mathrm{M}\right)$. Particularly, DC3 inhibited the cell migration and invasion of LNCap cells, and the expansion of the nude mice tumor in prostate capan2 xenografts (1 mg/kg, inoculated subcutaneously) [246]. Bauhinia purprea agglutinin (BPA) is a recognized lectin that distinguishes galactosyl glycoproteins and glycolipids. BPA-PEG-modified liposomes (BPA-PEG-LP) encapsulating anticancer drugs for the treatment of prostate cancer. In a in vivo study, BPA-PEG-LP accumulated after the i.v. injection to DU145 solid cancer-bearing mice, and intensely bound to the cancer cells. Also, the same mice i.v. injected with BPA-PEG-LP encapsulating doxorubicin (BPA-PEG-LPDOX, ) or PEG-modified liposomes encapsulating DOX (PEG-LPDOX), BPA-PEG-LPDOX considerably inhibited the growth of the DU145 cancer cells, while PEG-LPDOX exhibited little anticancer effect [245]. DLasiL, a lectin isolated from seeds of the Dioclea lasiocarpa indicated highly potent antiproliferative activity against PC-3 (low nanomolar) and was as high or more potent than the lectins ConBr (Canavalia brasiliensis), ConM (Canavalia maritima) and DSclerL (Dioclea sclerocarpa) against the same cells [247].

\subsubsection{Fatty Acids}

(E)-ethyl 8-methylnon-6-enoate from C. chinense showed antiproliferative effects on LNCaP, DU145 and PC-3 lines (76\%, 41\% and $62 \%$ at $100 \mu \mathrm{M}$, respectively) [123]. Juglone from plants inhibits the migration and invasion of LNCaP and LNCaP-AI cell lines, increasing the expression of the epithelial marker E-cadherin while declining the expression of mesenchymal markers (N-cadherin and vimentin) in a dose-dependent manner. This compound also suppresses EMT via the Akt/GSK-3ß/Snail pathway, therefore diminishing the invasiveness of prostate cancer cells [223].

\section{Evidence from Clinical Studies}

Prostate cancer patients are progressively using complementary and alternative medicines in order to support the immune system in addition to conventional treatments (Table 5). This minimizes morbidity related to conventional treatments, enhances the quality of life, eventually, in the hope of finding a cure when conventional treatment fails [265].

In a retrospective study, danshen (Salvia miltiorrhiza) showed in vivo protective effects in prostate cancer patients. A total of 40,692 prostate cancer patients were followed for 15 years. The survival rate analyses confirmed a strong dose-dependent and time-dependent connection between the use of danshen and survival (an increase of 5-10\%), supporting the protective effects of danshen on prostate cancer patients. These results might serve as a base for a new therapeutic approach for the treatment of prostate cancer [266]. Another retrospective cohort study, between 1998 and 2003 in Taiwan, organized patients as traditional Chinese medicine (TCM) users or nonusers, revealed that Chai-Hu-Jia-Long-Gu-Mu-Li-Tang was the most significant TCM formulae for improving survival in metastatic prostate cancer patients (adjusted hazard ratio 0.18). The formula was later approved by the Ministry of Health and Welfare, Taiwan [267].

Pantuck, et al. [268] described the first clinical trial of pomegranate juice in prostate cancer patients. In a placebo-controlled study, pomegranate juice consumption showed to have a noteworthy extension of PSA doubling time (PSADT), coupled with consistent prostate cancer in vitro cell effects on proliferation, apoptosis, and oxidative stress [268]. In phase II clinical trial, a prolongation of PSA doubling following consumption was exposed, and there were indicators of oxidative stress 
enhanced in human subjects [269]. These results were corroborated in another phase II study, in men receiving pomegranate seed extract [270]. In fact, two doses of pomegranate extract (POMx) treatment was correlated with $\mathrm{a} \geq 6$ month rise in PSADT in both treatments, with no adverse effects detected. However, it is important to note that the implication of this in-study reduction of PSADT remains uncertain and a placebo-controlled study in this patient population is still required [270]. In another study, compared with placebo, pomegranate extract did not significantly extend PSADT in prostate cancer patients with high PSA, after primary therapy. It was noted that men with the manganese superoxide dismutase (MnSOD) AA genotype might embody a more sensitive group to the antiproliferative effects of pomegranate on PSADT; however, this finding needs more testing and validation [160].

Polyphenol-rich foods such as pomegranate, green tea, broccoli, and turmeric have proven to possess anti-neoplastic activities in laboratory models. In a randomized controlled trial, 199 men, average age 74 years-old, with localized prostate cancer, were randomized to receive an oral capsule containing a blend of pomegranate, green tea, broccoli, and turmeric, or an identical placebo for 6 months. Results revealed that the median rise in PSA in the food supplement group was $14.7 \%$, in contrast to $78.5 \%$ in the placebo group. No significant differences within the predetermined subgroups (e.g., age, treatment category, body mass index, cholesterol, blood pressure, blood sugar, C-reactive protein or adverse events), however more evaluations are required to validate these results [271].

Diets high in cruciferous vegetables are correlated with a lower risk of incidence and aggressiveness of prostate cancer. A clinical trial in 20 men with recurrent prostate cancer, receiving $200 \mu \mathrm{M} /$ day of sulforaphane-rich extracts for a maximum period of 20 weeks, exhibited a general increase of the on-treatment PSADT (6.1 months) compared with the pre-treatment PSADT (9.6 months). No grade 3 adverse events were described, but a further trial at higher doses is needed to verify the role of these extracts in the prevention or treatment of prostate cancer [272].

Table 5. Clinical trials showing the anti-prostate cancer potential of plant-derived phytochemicals.

\begin{tabular}{ccc}
\hline Phytochemicals/Formulae & Bioactive Effect & Reference \\
\hline Danshen (Salvia miltiorrhiza) & Protective effects; Improved survival (5-10\%) & {$[266]$} \\
TCM formulae & Improved survival & {$[267]$} \\
(Chai-Hu-Jia-Long-Gu-Mu-Li-Tang) & Extension of PSA doubling time, with no & {$[268-270]$} \\
Pomegranate juice & adverse effects \\
Pomegranate, green tea, broccoli, & Decreased PSA levels & {$[271]$} \\
turmeric & Decreased the circulating levels of androgen & precursors \\
Resveratrol & Extension of PSA doubling time, with no & adverse effects \\
PC-SPEC & Decreased PSA levels & {$[274]$} \\
\hline
\end{tabular}

In a randomized placebo-controlled clinical study, two doses of resveratrol (150 $\mathrm{mg}$ or $1000 \mathrm{mg}$ resveratrol daily) was administered for 4 months. The results showed that resveratrol decreases the levels of circulating androgen precursors, nonetheless with no effect on testosterone, dihydro-testosterone, PSA levels or prostate volume in middle-aged men [273]. In a phase I clinical trial, 14 men with recurrent prostate cancer received different doses of resveratrol of MSKE, a pulverized muscadine grape $(V$. rotundifolia) consisting in $4.4 \mu \mathrm{g}$ resveratrol/500 $\mathrm{mg}$ MSKE for a period of 2-31 months. The highest MSKE dose (4000 $\mathrm{mg}$ ) was confirmed safe and able to elongate the PSADT with a median of 5.3 months. Both low-dose $(500 \mathrm{mg})$ and high-dose $(4000 \mathrm{mg})$ MSKE are being further explored in a randomized, multicenter, placebo-controlled, dose-evaluating phase II trial [274].

PC-SPEC, a comprehensive study of a Chinese formula, consisting of eight medicinal plants, was applied in 69 patients with prostate cancer; they were treated with $320 \mathrm{mg} / 3$ times a day. 
The outcome revealed that $82 \%$ decreased PSA in 2 months, $78 \%$ in 6 months and $88 \%$ in 12 months post-treatment in some side effects (e.g., phlebitis) [275].

\section{Conclusions and Future Perspectives}

The present report suggests that several medicinal plants, herbs, and isolated phytochemicals possess interesting potential both in the prevention and even treatment of prostate cancer. Although multiple plant species have shown interesting biological attributes, it is worth mentioning that it is their chemical constituents that have been shown to play a preponderant role in their final bioactivity. Phenolic compounds are ones that have revealed the more promising potential, followed by alkaloids and terpenoids. Anyway, and despite encouraging data seen in some of these interventions, only randomized controlled trials can deliver adequate evidence to create universal guidelines. In addition, unfortunately, only a scarce number of phytochemicals have been undergone clinical trials to assess their anti-prostate cancer potential. The lack of clinical evidence to support the in vitro and in vivo results need further clinical studies of the widespread use of the reported ingredients for chemoprevention and therapy of prostate cancer.

Author Contributions: All authors contributed to the manuscript. Conceptualization, B.S. and J.S.-R.; validation investigation, resources, data curation, writing-all authors; review and editing, J.S.-R., B.S., M.M., C.F.R., N.M., and W.C.C., All the authors read and approved the final manuscript.

Funding: This research received no external funding.

Acknowledgments: This work was supported by CONICYT PIA/APOYO CCTE AFB170007. N. Martins would like to thank the Portuguese Foundation for Science and Technology (FCT-Portugal) for the Strategic project ref. UID/BIM/04293/2013 and "NORTE2020 - Programa Operacional Regional do Norte" (NORTE-01-0145-FEDER-000012) and C. F. Rodrigues for the UID/EQU/00511/2019 Project-Laboratory of Process Engineering, Environment, Biotechnology, and Energy_LEPABE financed by national funds through FCT/MCTES (PIDDAC).

Conflicts of Interest: The authors declare no conflict of interest.

\section{References}

1. Etemadi, A.; Sadjadi, A.; Semnani, S.; Nouraie, S.M.; Khademi, H.; Bahadori, M. Cancer registry in Iran: A brief overview. Arch. Iran. Med. 2008, 11, 577-580. [PubMed]

2. Casey, S.C.; Amedei, A.; Aquilano, K.; Azmi, A.S.; Benencia, F.; Bhakta, D.; Bilsland, A.E.; Boosani, C.S.; Chen, S.; Ciriolo, M.R.; et al. Cancer prevention and therapy through the modulation of the tumor microenvironment. Semin. Cancer Biol. 2015, 35, S199-S223. [CrossRef] [PubMed]

3. Siegel, R.L.; Fedewa, S.A.; Miller, K.D.; Goding-Sauer, A.; Pinheiro, P.S.; Martinez-Tyson, D.; Jemal, A. Cancer statistics for hispanics/latinos, 2015. CA Cancer J. Clin. 2015, 65, 457-480. [CrossRef] [PubMed]

4. Shokoohinia, Y.; Jafari, F.; Mohammadi, Z.; Bazvandi, L.; Hosseinzadeh, L.; Chow, N.; Bhattacharyya, P.; Farzaei, M.H.; Farooqi, A.A.; Nabavi, S.M.; et al. Potential anticancer properties of osthol: A comprehensive mechanistic review. Nutrients 2018, 10, 36. [CrossRef] [PubMed]

5. Sharma, P.; McClees, S.F.; Afaq, F. Pomegranate for prevention and treatment of cancer: An update. Molecules 2017, 22, 177. [CrossRef] [PubMed]

6. Novio, S.; Cartea, M.E.; Soengas, P.; Freire-Garabal, M.; Nunez-Iglesias, M.J. Effects of Brassicaceae isothiocyanates on prostate cancer. Molecules 2016, 21, 626. [CrossRef] [PubMed]

7. Torre, L.A.; Siegel, R.L.; Ward, E.M.; Jemal, A. Global cancer incidence and mortality rates and trends-An update. Cancer Epidemiol. Prev. Biomark. 2015, 25, 16-27. [CrossRef] [PubMed]

8. Giovannucci, E.; Harlan, D.M.; Archer, M.C.; Bergenstal, R.M.; Gapstur, S.M.; Habel, L.A.; Pollak, M.; Regensteiner, J.G.; Yee, D. Diabetes and cancer: A consensus report. CA Cancer J. Clin. 2010, 60, 207-221. [CrossRef]

9. Ferlay, J.; Soerjomataram, I.; Ervik, M.; Dikshit, R.; Eser, S.; Mathers, C.; Rebelo, M.; Parkin, D.; Forman, D.; Bray, F. Globocan 2012 v1.0, Cancer Incidence and Mortality Worldwide: Iarc Cancerbase No. 11; International Agency for Research on Cancer: Lyon, France, 2015.

10. Attard, G.; Parker, C.; Eeles, R.A.; Schroder, F.; Tomlins, S.A.; Tannock, I.; Drake, C.G.; de Bono, J.S. Prostate cancer. Lancet 2016, 387, 70-82. [CrossRef] 
11. Klotz, L.; Vesprini, D.; Sethukavalan, P.; Jethava, V.; Zhang, L.; Jain, S.; Yamamoto, T.; Mamedov, A.; Loblaw, A. Long-term follow-up of a large active surveillance cohort of patients with prostate cancer. J. Clin. Oncol. Off. J. Am. Soc. Clin. Oncol. 2015, 33, 272-277. [CrossRef]

12. Abedi, A.-R.; Fallah-Karkan, M.; Allameh, F.; Ranjbar, A.; Shadmehr, A. Incidental prostate cancer: A 10-year review of a tertiary center, Tehran, Iran. Res. Rep. Urol. 2018, 10, 1-6. [CrossRef] [PubMed]

13. Daniyal, M.; Siddiqui, Z.A.; Akram, M.; Asif, H.; Sultana, S.; Khan, A. Epidemiology, etiology, diagnosis and treatment of prostate cancer. Asian Pac. J. Cancer Prev. 2014, 15, 9575-9578. [CrossRef] [PubMed]

14. Pernar, C.H.; Ebot, E.M.; Wilson, K.M.; Mucci, L.A. The epidemiology of prostate cancer. Cold Spring Harb. Perspect. Med. 2018, 3, a030361. [CrossRef] [PubMed]

15. Barve, A.; Khor, T.O.; Hao, X.; Keum, Y.S.; Yang, C.S.; Reddy, B.; Kong, A.N. Murine prostate cancer inhibition by dietary phytochemicals-Curcumin and phenyethylisothiocyanate. Pharm. Res. 2008, 25, 2181-2189. [CrossRef]

16. Dunn, M.W.; Kazer, M.W. Prostate cancer overview. Semin. Oncol. Nurs. 2011, 27, 241-250. [CrossRef] [PubMed]

17. Ferlay, J.; Soerjomataram, I.; Dikshit, R.; Eser, S.; Mathers, C.; Rebelo, M.; Parkin, D.M.; Forman, D.; Bray, F. Cancer incidence and mortality worldwide: Sources, methods and major patterns in globocan 2012. Int. J. Cancer 2015, 136, E359-E386. [CrossRef] [PubMed]

18. Bashir, M.N. Epidemiology of prostate cancer. Asian Pac. J. Cancer Prev. 2015, 16, 5137-5141. [CrossRef]

19. American Cancer Society. Key Statistics for Prostate Cancer; American Cancer Society: Atlanta, GA, USA, 2018.

20. Packer, J.R.; Maitland, N.J. The molecular and cellular origin of human prostate cancer. Biochim. Biophys. Acta 2016, 1863, 1238-1260. [CrossRef]

21. Mills, P.K.; Beeson, W.L.; Phillips, R.L.; Fraser, G.E. Cohort study of diet, lifestyle, and prostate cancer in adventist men. Cancer 1989, 64, 598-604. [CrossRef]

22. Chan, J.M.; Stampfer, M.J.; Giovannucci, E.L. What causes prostate cancer? A brief summary of the epidemiology. Semin. Cancer Biol. 1998, 8, 263-273. [CrossRef]

23. Pandey, M.K.; Gupta, S.C.; Nabavizadeh, A.; Aggarwal, B.B. Regulation of cell signaling pathways by dietary agents for cancer prevention and treatment. Semin. Cancer Biol. 2017, 46, 158-181. [CrossRef] [PubMed]

24. Mantovani, A.; Allavena, P.; Sica, A.; Balkwill, F. Cancer-related inflammation. Nature 2008, 454, 436-444. [CrossRef] [PubMed]

25. Hamilton, W.; Sharp, D. Symptomatic diagnosis of prostate cancer in primary care: A structured review. Br. J. Gen. Pr. 2004, 54, 617-621.

26. Young, S.-M.; Bansal, P.; Vella, E.T.; Finelli, A.; Levitt, C.; Loblaw, A. Systematic review of clinical features of suspected prostate cancer in primary care. Can. Fam. Physician 2015, 61, e26-e35. [PubMed]

27. Quinlan, M.; O’Daly, B.; O’Brien, M.; Gardner, S.; Lennon, G.; Mulvin, D.; Quinlan, D. The value of appropriate assessment prior to specialist referral in men with prostatic symptoms. Ir. J. Med Sci. 2009, 178, 281-285. [CrossRef] [PubMed]

28. Nam, R.K.; Kattan, M.W.; Chin, J.L.; Trachtenberg, J.; Singal, R.; Rendon, R.; Klotz, L.H.; Sugar, L.; Sherman, C.; Izawa, J. Prospective multi-institutional study evaluating the performance of prostate cancer risk calculators. J. Clin. Oncol. Off. J. Am. Soc. Clin. Oncol. 2011, 29, 2959-2964. [CrossRef]

29. Brown, M.L.; Potosky, A.L.; Thompson, G.B.; Kessler, L.K. The knowledge and use of screening tests for colorectal and prostate cancer: Data from the 1987 national health interview survey. Prev. Med. 1990, 19, 562-574. [CrossRef]

30. Barry, M.J. Screening for Prostate Cancer-The Controversy That Refuses to Die; Massachusetts Medical Society: Waltham, MA, USA, 2009.

31. Siegel, R.; Ma, J.; Zou, Z.; Jemal, A. Cancer statistics, 2014. CA Cancer J. Clin. 2014, 64, 9-29. [CrossRef]

32. Center, M.M.; Jemal, A.; Lortet-Tieulent, J.; Ward, E.; Ferlay, J.; Brawley, O.; Bray, F. International variation in prostate cancer incidence and mortality rates. Eur. Urol. 2012, 61, 1079-1092. [CrossRef]

33. Thompson, I.M.; Pauler, D.K.; Goodman, P.J.; Tangen, C.M.; Lucia, M.S.; Parnes, H.L.; Minasian, L.M.; Ford, L.G.; Lippman, S.M.; Crawford, E.D. Prevalence of prostate cancer among men with a prostate-specific antigen level $\leq 4.0 \mathrm{ng}$ per milliliter. N. Engl. J. Med. 2004, 350, 2239-2246. [CrossRef]

34. Ghai, S.; Haider, M.A. Multiparametric-mri in diagnosis of prostate cancer. Indian J. Urol. Iju J. Urol. Soc. India 2015, 31, 194. [CrossRef] [PubMed] 
35. Cook, G.J.; Azad, G.; Padhani, A.R. Bone imaging in prostate cancer: The evolving roles of nuclear medicine and radiology. Clin. Transl. Imaging 2016, 4, 439-447. [CrossRef] [PubMed]

36. Zheng, X.-Y.; Zhang, P.; Xie, L.-P.; You, Q.-H.; Cai, B.-S.; Qin, J. Prostate-specific antigen velocity (PSAV) and PSAV per initial volume (PSAVD) for early detection of prostate cancer in Chinese men. Asian Pac. J. Cancer Prev. 2012, 13, 5529-5533. [CrossRef] [PubMed]

37. Hayes, J.H.; Barry, M.J. Screening for prostate cancer with the prostate-specific antigen test: A review of current evidence. JAMA 2014, 311, 1143-1149. [CrossRef] [PubMed]

38. Eggener, S.E.; Cifu, A.S.; Nabhan, C. Prostate cancer screening. JAMA 2015, 314, 825-826. [CrossRef]

39. Prensner, J.R.; Rubin, M.A.; Wei, J.T.; Chinnaiyan, A.M. Beyond psa: The next generation of prostate cancer biomarkers. Sci. Transl. Med. 2012, 4, rv123-rv127. [CrossRef]

40. Cuzick, J.; Thorat, M.A.; Andriole, G.; Brawley, O.W.; Brown, P.H.; Culig, Z.; Eeles, R.A.; Ford, L.G.; Hamdy, F.C.; Holmberg, L. Prevention and early detection of prostate cancer. Lancet Oncol. 2014, 15, e484-e492. [CrossRef]

41. Jahn, J.L.; Giovannucci, E.L.; Stampfer, M.J. The high prevalence of undiagnosed prostate cancer at autopsy: Implications for epidemiology and treatment of prostate cancer in the prostate-specific antigen-era. Int. J. Cancer 2015, 137, 2795-2802. [CrossRef]

42. Chan, J.M.; Giovannucci, E.L. Vegetables, fruits, associated micronutrients, and risk of prostate cancer. Epidemiol. Rev. 2001, 23, 82-86. [CrossRef]

43. Bashir, M.N.; Ahmad, M.R.; Malik, A. Risk factors of prostate cancer: A case-control study in Faisalabad, Pakistan. Asian Pac. J. Cancer Prev. 2014, 15, 10237-10240. [CrossRef]

44. Howlader, N.; Noone, A.; Krapcho, M.; Miller, D.; Bishop, K.; Altekruse, S.; Kosary, C.; Yu, M.; Ruhl, J.; Tatalovich, Z. Seer Cancer Statistics Review. 1975-2013. National Cancer Institute: Bethesda, MD, USA. Available online: https://seer.cancer.gov/archive/csr/1975_2013/ (accessed on 10 September 2018).

45. Goggins, W.B.; Wong, G. Cancer among asian indians/pakistanis living in the united states: Low incidence and generally above average survival. Cancer Causes Control. 2009, 20, 635-643. [CrossRef] [PubMed]

46. Hemminki, K.; Ankerst, D.P.; Sundquist, J.; Mousavi, S.M. Prostate cancer incidence and survival in immigrants to Sweden. World J. Urol. 2013, 31, 1483-1488. [CrossRef] [PubMed]

47. Kiciński, M.; Vangronsveld, J.; Nawrot, T.S. An epidemiological reappraisal of the familial aggregation of prostate cancer: A meta-analysis. PLoS ONE 2011, 6, e27130. [CrossRef] [PubMed]

48. Eeles, R.A.; Al Olama, A.A.; Benlloch, S.; Saunders, E.J.; Leongamornlert, D.A.; Tymrakiewicz, M.; Ghoussaini, M.; Luccarini, C.; Dennis, J.; Jugurnauth-Little, S. Identification of 23 new prostate cancer susceptibility loci using the icogs custom genotyping array. Nat. Genet. 2013, 45, 385. [CrossRef] [PubMed]

49. Hoffmann, T.J.; Van Den Eeden, S.K.; Sakoda, L.C.; Jorgenson, E.; Habel, L.A.; Graff, R.E.; Passarelli, M.N.; Cario, C.L.; Emami, N.C.; Chao, C.R. A large multi-ethnic genome-wide association study of prostate cancer identifies novel risk variants and substantial ethnic differences. Cancer Discov. 2015, 5, 878-891. [CrossRef] [PubMed]

50. Hemminki, K.; Czene, K. Attributable risks of familial cancer from the family-cancer database. Cancer Epidemiol. Prev. Biomark. 2002, 11, 1638-1644.

51. Möller, E.; Wilson, K.M.; Batista, J.L.; Mucci, L.A.; Bälter, K.; Giovannucci, E. Body size across the life course and prostate cancer in the health professionals follow-up study. Int. J. Cancer 2016, 138, 853-865. [CrossRef] [PubMed]

52. Zuccolo, L.; Harris, R.; Gunnell, D.; Oliver, S.; Lane, J.A.; Davis, M.; Donovan, J.; Neal, D.; Hamdy, F.; Beynon, R. Height and prostate cancer risk: A large nested case-control study (protect) and meta-analysis. Cancer Epidemiol. Prev. Biomark. 2008, 17, 2325-2336. [CrossRef]

53. Anuurad, E.; Shiwaku, K.; Nogi, A.; Kitajima, K.; Enkhmaa, B.; Shimono, K.; Yamane, Y. The new bmi criteria for asians by the regional office for the western pacific region of who are suitable for screening of overweight to prevent metabolic syndrome in elder Japanese workers. J. Occup. Health 2003, 45, 335-343. [CrossRef]

54. Cao, Y.; Ma, J. Body-mass index, prostate cancer-specific mortality and biochemical recurrence: A systematic review and meta-analysis. Cancer Prev. Res. 2011, 4, 486-501. [CrossRef]

55. Ma, J.; Li, H.; Giovannucci, E.; Mucci, L.; Qiu, W.; Nguyen, P.L.; Gaziano, J.M.; Pollak, M.; Stampfer, M.J. Prediagnostic body-mass index, plasma c-peptide concentration, and prostate cancer-specific mortality in men with prostate cancer: A long-term survival analysis. Lancet Oncol. 2008, 9, 1039-1047. [CrossRef] 
56. Joshu, C.E.; Mondul, A.M.; Menke, A.; Meinhold, C.L.; Han, M.; Humphreys, E.; Freedland, S.J.; Walsh, P.C.; Platz, E.A. Weight gain is associated with an increased risk of prostate cancer recurrence after prostatectomy in the PSA era. Cancer Prev. Res. 2011, 4, 544-551. [CrossRef] [PubMed]

57. World Health Organization. Global Status Report on Alcohol and Health; World Health Organization: Geneva, Switzerland, 2014.

58. Kenfield, S.A.; Stampfer, M.J.; Chan, J.M.; Giovannucci, E. Smoking and prostate cancer survival and recurrence. JAMA 2011, 305, 2548-2555. [CrossRef] [PubMed]

59. Richman, E.L.; Kenfield, S.A.; Stampfer, M.J.; Paciorek, A.; Carroll, P.R.; Chan, J.M. Physical activity after diagnosis and risk of prostate cancer progression: Data from the cancer of the prostate strategic urologic research endeavor. Cancer Res. 2011, 71, 3889-3895. [CrossRef] [PubMed]

60. Loprinzi, P.D.; Kohli, M. Effect of Physical Activity and Sedentary Behavior on Serum Prostate-Specific Antigen Concentrations: Results from the National Health and Nutrition Examination Survey (NHANES), 2003-2006, Mayo Clinic Proceedings; Elsevier: Amsterdam, The Netherlands, 2013; pp. 11-21.

61. Holt, S.K.; Kwon, E.M.; Koopmeiners, J.S.; Lin, D.W.; Feng, Z.; Ostrander, E.A.; Peters, U.; Stanford, J.L. Vitamin d pathway gene variants and prostate cancer prognosis. Prostate 2010, 70, 1448-1460. [CrossRef] [PubMed]

62. Kristal, A.R.; Arnold, K.B.; Neuhouser, M.L.; Goodman, P.; Platz, E.A.; Albanes, D.; Thompson, I.M. Diet, supplement use, and prostate cancer risk: Results from the prostate cancer prevention trial. Am. J. Epidemiol. 2010, 172, 566-577. [CrossRef]

63. Mahmood, S.; Qasmi, G.; Ahmed, A.; Kokab, F.; Zahid, M.F.; Afridi, M.I.; Razzaq, A. Lifestyle factors associated with the risk of prostate cancer among Pakistani men. J. Ayub Med. Coll. Abbottabad 2012, 24, 122-126.

64. Butler, L.M.; Wong, A.S.; Koh, W.-P.; Wang, R.; Yuan, J.-M.; Mimi, C.Y. Calcium intake increases risk of prostate cancer among Singapore Chinese. Cancer Res. 2010, 70, 4941-4948. [CrossRef]

65. De Martel, C.; Ferlay, J.; Franceschi, S.; Vignat, J.; Bray, F.; Forman, D.; Plummer, M. Global burden of cancers attributable to infections in 2008: A review and synthetic analysis. Lancet Oncol. 2012, 13, 607-615. [CrossRef]

66. Sutcliffe, S.; Platz, E.A. Inflammation and prostate cancer: A focus on infections. Curr. Urol. Rep. 2008, 9, 243. [CrossRef]

67. Sutcliffe, S.; Neace, C.; Magnuson, N.S.; Reeves, R.; Alderete, J. Trichomonosis, a common curable sti, and prostate carcinogenesis—a proposed molecular mechanism. PLoS Pathog. 2012, 8, e1002801. [CrossRef] [PubMed]

68. Meyer, T.E.; Coker, A.L.; Sanderson, M.; Symanski, E. A case-control study of farming and prostate cancer in African-American and Caucasian men. Occup. Environ. Med. 2007, 64, 155-160. [CrossRef] [PubMed]

69. Nair-Shalliker, V.; Smith, D.P.; Egger, S.; Hughes, A.M.; Kaldor, J.M.; Clements, M.; Kricker, A.; Armstrong, B.K. Sun exposure may increase risk of prostate cancer in the high UV environment of new south wales, Australia: A case-control study. Int. J. Cancer 2012, 131, E726-E732. [CrossRef] [PubMed]

70. Myles, P.; Evans, S.; Lophatananon, A.; Dimitropoulou, P.; Easton, D.; Key, T.; Pocock, R.; Dearnaley, D.; Guy, M.; Edwards, S. Diagnostic radiation procedures and risk of prostate cancer. Br. J. Cancer 2008, 98, 1852. [CrossRef] [PubMed]

71. Zuccolo, L.; Lewis, S.J.; Donovan, J.L.; Hamdy, F.C.; Neal, D.E.; Smith, G.D. Alcohol consumption and PSA-detected prostate cancer risk-A case-control nested in the protect study. Int. J. Cancer 2013, 132, 2176-2185. [CrossRef] [PubMed]

72. McGregor, S.E.; Courneya, K.S.; Kopciuk, K.A.; Tosevski, C.; Friedenreich, C.M. Case-control study of lifetime alcohol intake and prostate cancer risk. Cancer Causes Control 2013, 24, 451-461. [CrossRef] [PubMed]

73. Endogenous Hormones and Prostate Cancer Collaborative Group; Roddam, A.W.; Allen, N.E.; Appleby, P.; Key, T.J. Endogenous sex hormones and prostate cancer: A collaborative analysis of 18 prospective studies. J. Natl. Cancer Inst. 2008, 100, 170-183.

74. Nelles, J.L.; Hu, W.-Y.; Prins, G.S. Estrogen action and prostate cancer. Expert Rev. Endocrinol. Metab. 2011, 6, $437-451$. [CrossRef] [PubMed]

75. Nelson, A.W.; Tilley, W.D.; Neal, D.E.; Carroll, J.S. Estrogen receptor beta in prostate cancer: Friend or foe? Endocr. Relat. Cancer 2014, 21, T219-T234.

76. Roddam, A.W.; Allen, N.E.; Appleby, P.; Key, T.J.; Ferrucci, L.; Carter, H.B.; Metter, E.J.; Chen, C.; Weiss, N.S.; Fitzpatrick, A. Insulin-like growth factors, their binding proteins, and prostate cancer risk: Analysis of individual patient data from 12 prospective studies. Ann. Intern. Med. 2008, 149, 461-471. 
77. Uzoh, C.; Holly, J.; Biernacka, K.; Persad, R.; Bahl, A.; Gillatt, D.; Perks, C. Insulin-like growth factor-binding protein-2 promotes prostate cancer cell growth via igf-dependent or-independent mechanisms and reduces the efficacy of docetaxel. Br. J. Cancer 2011, 104, 1587. [CrossRef] [PubMed]

78. Robinson, D.; Van Allen, E.M.; Wu, Y.-M.; Schultz, N.; Lonigro, R.J.; Mosquera, J.-M.; Montgomery, B.; Taplin, M.-E.; Pritchard, C.C.; Attard, G. Integrative clinical genomics of advanced prostate cancer. Cell 2015, 161, 1215-1228. [CrossRef] [PubMed]

79. Klein, A.J.S.E.A. Epidemiology, etiology, and prevention of prostate cancer. In Campbell-Walsh Urology, 11th ed.; Wein, A.J., Ed.; Elsevier: Philadelphia, PA, USA, 2016; Volume 3, pp. 2543-2564.

80. Sun, F.; Oyesanmi, O.; Fontanarosa, J.; Reston, J.; Guzzo, T.; Schoelles, K. Therapies for Clinically Localized Prostate Cancer: Update of a 2008 Systematic Review; Agency for Healthcare Research and Quality: Rockville, MD, USA, 2014.

81. Mottet, N.; Bellmunt, J.; Bolla, M.; Briers, E.; Cumberbatch, M.G.; De Santis, M.; Fossati, N.; Gross, T.; Henry, A.M.; Joniau, S. EAU-ESTRO-SIOG guidelines on prostate cancer. Part 1: Screening, diagnosis, and local treatment with curative intent. Eur. Urol. 2017, 71, 618-629. [CrossRef] [PubMed]

82. Cornford, P.; Bellmunt, J.; Bolla, M.; Briers, E.; De Santis, M.; Gross, T.; Henry, A.M.; Joniau, S.; Lam, T.B.; Mason, M.D. EAU-ESTRO-SIOG guidelines on prostate cancer. Part II: Treatment of relapsing, metastatic, and castration-resistant prostate cancer. Eur. Urol. 2017, 71, 630-642. [CrossRef] [PubMed]

83. Wang, G.; Hu, F.B.; Mistry, K.B.; Zhang, C.; Ren, F.; Huo, Y.; Paige, D.; Bartell, T.; Hong, X.; Caruso, D.; et al. Association between maternal prepregnancy body mass index and plasma folate concentrations with child metabolic health. JAMA Pediatrics 2016, 170, e160845. [CrossRef] [PubMed]

84. Peeling, P.; Binnie, M.J.; Goods, P.S.R.; Sim, M.; Burke, L.M. Evidence-based supplements for the enhancement of athletic performance. Int. J. Sport Nutr. Exerc. Metab. 2018, 28, 178-187. [CrossRef] [PubMed]

85. Young, H.H. The early diagnosis and radical cure of carcinoma of the prostate: Being a study of 40 cases and presentation of a radical operation which was carried out in four cases. Johns Hopkins Hosp. Bull. 1905, 16, 315-321.

86. Ramsay, C.; Pickard, R.; Robertson, C.; Close, A.; Vale, L.; Armstrong, N.; Barocas, D.; Eden, C.; Fraser, C.; Gurung, T. Systematic review and economic modelling of the relative clinical benefit and cost-effectiveness of laparoscopic surgery and robotic surgery for removal of the prostate in men with localised prostate cancer. Health Technol. Assess. 2012, 16, 1. [CrossRef]

87. Keyes, M.; Crook, J.; Morton, G.; Vigneault, E.; Usmani, N.; Morris, W.J. Treatment options for localized prostate cancer. Can. Fam. Physician 2013, 59, 1269-1274.

88. Litwin, M.S.; Tan, H.-J. The diagnosis and treatment of prostate cancer: A review. JAMA 2017, 317, $2532-2542$. [CrossRef]

89. Bayoumi, A.M.; Brown, A.D.; Garber, A.M. Cost-effectiveness of androgen suppression therapies in advanced prostate cancer. J. Natl. Cancer Inst. 2000, 92, 1731-1739. [CrossRef] [PubMed]

90. Oefelein, M.G.; Feng, A.; Scolieri, M.J.; Ricchiutti, D.; Resnick, M.I. Reassessment of the definition of castrate levels of testosterone: Implications for clinical decision making. Urology 2000, 56, 1021-1024. [CrossRef]

91. Seidenfeld, J.; Samson, D.J.; Hasselblad, V.; Aronson, N.; Albertsen, P.C.; Bennett, C.L.; Wilt, T.J. Single-therapy androgen suppression in men with advanced prostate cancer: A systematic review and meta-analysis. Ann. Intern. Med. 2000, 132, 566-577. [CrossRef] [PubMed]

92. Crawford, E.D.; Shore, N.D.; Moul, J.W.; Tombal, B.; Schröder, F.H.; Miller, K.; Boccon-Gibod, L.; Malmberg, A.; Olesen, T.K.; Persson, B.-E. Long-term tolerability and efficacy of degarelix: 5-year results from a phase iii extension trial with a 1-arm crossover from leuprolide to degarelix. Urology 2014, 83, 1122-1128. [CrossRef] [PubMed]

93. Goenka, A.; Magsanoc, J.M.; Pei, X.; Schechter, M.; Kollmeier, M.; Cox, B.; Scardino, P.T.; Eastham, J.A.; Zelefsky, M.J. Long-term outcomes after high-dose postprostatectomy salvage radiation treatment. Int. J. Radiat. Oncol. Biol. Phys. 2012, 84, 112-118. [CrossRef] [PubMed]

94. Chen, C.P.; Weinberg, V.; Shinohara, K.; Roach, M., III; Nash, M.; Gottschalk, A.; Chang, A.J.; Hsu, I.-C. Salvage HDR brachytherapy for recurrent prostate cancer after previous definitive radiation therapy: 5-year outcomes. Int. J. Radiat. Oncol. Biol. Phys. 2013, 86, 324-329. [CrossRef]

95. Karnes, R.J.; Murphy, C.R.; Bergstralh, E.J.; DiMonte, G.; Cheville, J.C.; Lowe, V.J.; Mynderse, L.A.; Kwon, E.D. Salvage lymph node dissection for prostate cancer nodal recurrence detected by 11c-choline positron emission tomography/computerized tomography. J. Urol. 2015, 193, 111-116. [CrossRef] [PubMed] 
96. Allameh, F.; Rahavian, A.H.; Ghiasy, S. Prevalence of castration success rate in Iranian metastatic prostate cancer patients: A referral center statistics. Int. J. Cancer Manag. 2018, 11, e83613. [CrossRef]

97. Beer, T.; Garzotto, M.; Henner, W.; Eilers, K.; Wersinger, E. Multiple cycles of intermittent chemotherapy in metastatic androgen-independent prostate cancer. Br. J. Cancer 2004, 91, 1425. [CrossRef] [PubMed]

98. Dy, S.M.; Asch, S.M.; Naeim, A.; Sanati, H.; Walling, A.; Lorenz, K.A. Evidence-based standards for cancer pain management. J. Clin. Oncol. 2008, 26, 3879-3885. [CrossRef]

99. Esper, P.; Pienta, K. Supportive Care in the Patient with Hormone Refractory Prostate Cancer. Semin. Urol. Oncol. 1997, 15, 56-64. [PubMed]

100. Roehrborn, C.G.; Black, L.K. The economic burden of prostate cancer. BJU Int. 2011, 108, 806-813. [CrossRef] [PubMed]

101. National Cancer Institute. Online Summary of Trends in Us Cancer Control Measures. Available online: https://progressreport.cancer.gov/after/economic_burden (accessed on 12 September 2018).

102. Moghadam, M.F.; Rangchian, M.; Ayati, M.; Pourmand, G.; Zeinali, L.; Rasekh, H. Economic burden of prostate cancer in Iran. Value Health 2016, 19, A147. [CrossRef]

103. Restelli, U.; Ceresoli, G.L.; Croce, D.; Evangelista, L.; Maffioli, L.S.; Gianoncelli, L.; Bombardieri, E. Economic burden of the management of metastatic castrate-resistant prostate cancer in Italy: A cost of illness study. Cancer Manag. Res. 2017, 9, 789. [CrossRef] [PubMed]

104. Savithramma, N.; Rao, M.L.; Suhrulatha, D. Screening of medicinal plants for secondary metabolites. Middle-East. J. Sci. Res. 2011, 8, 579-584.

105. Petrovska, B.B. Historical review of medicinal plants' usage. Pharmacogn. Rev. 2012, 6, 1-5. [CrossRef] [PubMed]

106. Ghasemzadeh, A.; Ghasemzadeh, N. Flavonoids and phenolic acids: Role and biochemical activity in plants and human. J. Med. Plants Res. 2011, 5, 6697-6703. [CrossRef]

107. Cragg, G.M.; Newman, D.J. Natural product drug discovery in the next millennium. Pharm. Biol. 2001, 39 (Suppl. 1), 8-17.

108. Bodeker, G. Traditional health system: Valuing biodiversity for human health and wellbeing. In Cultural and Spiritual Values in Biodiversity; Posey, D.A., Ed.; Intermediate Technology Publications: London, UK, 2000; pp. 261-284.

109. Choi, Y.J.; Choi, Y.K.; Lee, K.M.; Cho, S.G.; Kang, S.Y.; Ko, S.G. Sh003 induces apoptosis of du145 prostate cancer cells by inhibiting ERK-involved pathway. BMC Complement. Altern. Med. 2016, 16, 507. [CrossRef]

110. Diab, K.A.; Guru, S.K.; Bhushan, S.; Saxena, A.K. In vitro anticancer activities of Anogeissus latifolia, Terminalia bellerica, Acacia catechu and Moringa oleiferna Indian plants. Asian Pac. J. Cancer Prev. 2015, 16, 6423-6428. [CrossRef]

111. Asadi-Samani, M.; Rafieian-Kopaei, M.; Lorigooini, Z.; Shirzad, H. A screening of growth inhibitory activity of iranian medicinal plants on prostate cancer cell lines. BioMedicine 2018, 8, 8. [CrossRef] [PubMed]

112. Bali, E.B.; Acik, L.; Elci, P.; Sarper, M.; Avcu, F.; Vural, M. In vitro anti-oxidant, cytotoxic and pro-apoptotic effects of Achillea teretifolia willd extracts on human prostate cancer cell lines. Pharmacogn. Mag. 2015, 11, S308-S315. [PubMed]

113. Bhandari, J.; Muhammad, B.; Thapa, P.; Shrestha, B.G. Study of phytochemical, anti-microbial, anti-oxidant, and anti-cancer properties of Allium wallichii. BMC Complement. Altern. Med. 2017, 17, 102. [CrossRef] [PubMed]

114. Al-Oqail, M.M.; El-Shaibany, A.; Al-Jassas, E.; Al-Sheddi, E.S.; Al-Massarani, S.M.; Farshori, N.N. In vitro anti-proliferative activities of aloe perryi flowers extract on human liver, colon, breast, lung, prostate and epithelial cancer cell lines. Pak. J. Pharm. Sci. 2016, 29, 723-729. [PubMed]

115. de Alencar, D.C.; Pinheiro, M.L.; Pereira, J.L.; de Carvalho, J.E.; Campos, F.R.; Serain, A.F.; Tirico, R.B.; Hernandez-Tasco, A.J.; Costa, E.V.; Salvador, M.J. Chemical composition of the essential oil from the leaves of Anaxagorea brevipes (Annonaceae) and evaluation of its bioactivity. Nat. Prod. Res. 2016, 30, 1088-1092. [CrossRef] [PubMed]

116. Zhang, J.; Wang, L.; Zhang, Y.; Li, L.; Tang, S.; Xing, C.; Kim, S.H.; Jiang, C.; Lu, J. Chemopreventive effect of Korean angelica root extract on tramp carcinogenesis and integrative "omic" profiling of affected neuroendocrine carcinomas. Mol. Carcinog. 2015, 54, 1567-1583. [CrossRef] [PubMed]

117. Tang, S.-N.; Zhang, J.; Wu, W.; Jiang, P.; Puppala, M.; Zhang, Y.; Xing, C.; Kim, S.-H.; Jiang, C.; Lü, J. Chemopreventive effects of Korean angelica vs. Its major pyranocoumarins on two lineages of transgenic adenocarcinoma of mouse prostate carcinogenesis. Cancer Prev. Res. 2015, 8, 835-844. [CrossRef] [PubMed] 
118. Deep, G.; Kumar, R.; Jain, A.K.; Dhar, D.; Panigrahi, G.K.; Hussain, A.; Agarwal, C.; El-Elimat, T.; Sica, V.P.; Oberlies, N.H.; et al. Graviola inhibits hypoxia-induced NADPH oxidase activity in prostate cancer cells reducing their proliferation and clonogenicity. Sci. Rep. 2016, 6, 23135. [CrossRef] [PubMed]

119. Huang, S.P.; Ho, T.M.; Yang, C.W.; Chang, Y.J.; Chen, J.F.; Shaw, N.S.; Horng, J.C.; Hsu, S.L.; Liao, M.Y.; $\mathrm{Wu}$, L.C.; et al. Chemopreventive potential of ethanolic extracts of luobuma leaves (Apocynum venetum L.) in androgen insensitive prostate cancer. Nutrients 2017, 9, 948. [CrossRef] [PubMed]

120. Chen, L.; Yan, F.; Chen, W.; Zhao, L.; Zhang, J.; Lu, Q.; Liu, R. Procyanidin from peanut skin induces antiproliferative effect in human prostate carcinoma cells du145. Chem. Biol. Interact. 2018, 288, 12-23. [CrossRef] [PubMed]

121. Cherian, A.M.; Snima, K.S.; Kamath, C.R.; Nair, S.V.; Lakshmanan, V.K. Effect of Baliospermum montanum nanomedicine apoptosis induction and anti-migration of prostate cancer cells. Biomed. Pharmacother. Biomed. Pharmacother. 2015, 71, 201-209. [CrossRef] [PubMed]

122. El-Merahbi, R.; Liu, Y.N.; Eid, A.; Daoud, G.; Hosry, L.; Monzer, A.; Mouhieddine, T.H.; Hamade, A.; Najjar, F.; Abou-Kheir, W. Berberis libanotica ehrenb extract shows anti-neoplastic effects on prostate cancer stem/progenitor cells. PLoS ONE 2014, 9, e112453. [CrossRef] [PubMed]

123. Fort, R.; Trinidad Barnech, J.; Dourron, J.; Colazzo, M.; Aguirre-Crespo, F.; Duhagon, M.; Álvarez, G. Isolation and structural characterization of bioactive molecules on prostate cancer from Mayan traditional medicinal plants. Pharmaceuticals 2018, 11, 78. [CrossRef] [PubMed]

124. Adaramoye, O.; Erguen, B.; Oyebode, O.; Nitzsche, B.; Hopfner, M.; Jung, K.; Rabien, A. Antioxidant, antiangiogenic and antiproliferative activities of root methanol extract of Calliandra portoricensis in human prostate cancer cells. J. Integr. Med. 2015, 13, 185-193. [CrossRef]

125. Pandey, S.; Walpole, C.; Cabot, P.J.; Shaw, P.N.; Batra, J.; Hewavitharana, A.K. Selective anti-proliferative activities of carica papaya leaf juice extracts against prostate cancer. Biomed. Pharmacother. Biomed. Pharmacother. 2017, 89, 515-523. [CrossRef] [PubMed]

126. Ramos-Silva, A.; Tavares-Carreon, F.; Figueroa, M.; De la Torre-Zavala, S.; Gastelum-Arellanez, A.; Rodriguez-Garcia, A.; Galan-Wong, L.J.; Aviles-Arnaut, H. Anticancer potential of Thevetia peruviana fruit methanolic extract. BMC Complement. Altern. Med. 2017, 17, 241. [CrossRef]

127. Podolak, I.; Olech, M.; Galanty, A.; Zaluski, D.; Grabowska, K.; Sobolewska, D.; Michalik, M.; Nowak, R. Flavonoid and phenolic acid profile by lc-ms/ms and biological activity of crude extracts from Chenopodium hybridum aerial parts. Nat. Prod. Res. 2016, 30, 1766-1770. [CrossRef]

128. Yousefi, B.; Abasi, M.; Abbasi, M.M.; Jahanban-Esfahlan, R. Anti-proliferative properties of cornus mass fruit in different human cancer cells. Asian Pac. J. Cancer Prev. 2015, 16, 5727-5731. [CrossRef]

129. Alonso-Castro, A.J.; Zapata-Morales, J.R.; Gonzalez-Chavez, M.M.; Carranza-Alvarez, C.; Hernandez-Benavides, D.M.; Hernandez-Morales, A. Pharmacological effects and toxicity of Costus pulverulentus c. Presl (Costaceae). J. Ethnopharmacol. 2016, 180, 124-130. [CrossRef]

130. Lee, M.S.; Lee, S.O.; Kim, K.R.; Lee, H.J. Sphingosine kinase-1 involves the inhibitory action of hif-1alpha by Chlorogenic acid in hypoxic du145 cells. Int. J. Mol. Sci. 2017, 18, 325. [CrossRef]

131. Zheng, J.; Zhou, Y.; Li, Y.; Xu, D.P.; Li, S.; Li, H.B. Spices for prevention and treatment of cancers. Nutrients 2016, 8, 495. [CrossRef] [PubMed]

132. D'Alessandro, A.M.; Mancini, A.; Lizzi, A.R.; De Simone, A.; Marroccella, C.E.; Gravina, G.L.; Tatone, C.; Festuccia, C. Crocus sativus stigma extract and its major constituent crocin possess significant antiproliferative properties against human prostate cancer. Nutr. Cancer 2013, 65, 930-942. [CrossRef] [PubMed]

133. Festuccia, C.; Mancini, A.; Gravina, G.L.; Scarsella, L.; Llorens, S.; Alonso, G.L.; Tatone, C.; Di Cesare, E.; Jannini, E.A.; Lenzi, A.; et al. Antitumor effects of saffron-derived carotenoids in prostate cancer cell models. Biomed Res. Int. 2014, 2014, 135048. [CrossRef]

134. Irshad, S.; Ashfaq, A.; Muazzam, A.; Yasmeen, A. Antimicrobial and anti-prostate cancer activity of turmeric (Curcuma longa L.) and black pepper (Piper nigrum L.) used in typical pakistani cuisine. Pak. J. Zool. 2017, 49, 1665-1669. [CrossRef]

135. Bayala, B.; Bassole, I.H.N.; Maqdasy, S.; Baron, S.; Simpore, J.; Lobaccaro, J.A. Cymbopogon citratus and Cymbopogon giganteus essential oils have cytotoxic effects on tumor cell cultures. Identification of citral as a new putative anti-proliferative molecule. Biochimie 2018, 153, 162-170. [CrossRef] [PubMed]

136. Tong, K.L.; Chan, K.L.; AbuBakar, S.; Low, B.S.; Ma, H.Q.; Wong, P.F. The in vitro and in vivo anti-cancer activities of a standardized quassinoids composition from Eurycoma longifolia on Incap human prostate cancer cells. PLoS ONE 2015, 10, e0121752. [CrossRef] [PubMed] 
137. Kassim, O.O.; Copeland, R.L.; Kenguele, H.M.; Nekhai, S.; Ako-Nai, K.A.; Kanaan, Y.M. Antiproliferative activities of Fagara xanthoxyloides and Pseudocedrela kotschyi against prostate cancer cell lines. Anticancer Res. 2015, 35, 1453-1458. [PubMed]

138. Lin, H.C.; Lin, J.Y. Immune cell-conditioned media suppress prostate cancer pc-3 cell growth correlating with decreased proinflammatory/anti-inflammatory cytokine ratios in the media using 5 selected crude polysaccharides. Integr. Cancer Ther. 2016, 15, Np13-Np25. [CrossRef] [PubMed]

139. Hanafi, M.M.M.; Afzan, A.; Yaakob, H.; Aziz, R.; Sarmidi, M.R.; Wolfender, J.L.; Prieto, J.M. In vitro pro-apoptotic and anti-migratory effects of Ficus deltoidea L. Plant extracts on the human prostate cancer cell lines pc3. Front. Pharmacol. 2017, 8, 895. [CrossRef] [PubMed]

140. Rayaprolu, S.J.; Hettiarachchy, N.S.; Horax, R.; Phillips, G.K.; Mahendran, M.; Chen, P. Soybean peptide fractions inhibit human blood, breast and prostate cancer cell proliferation. J. Food Sci. Technol. 2017, 54, 38-44. [CrossRef] [PubMed]

141. Park, S.Y.; Kwon, S.J.; Lim, S.S.; Kim, J.K.; Lee, K.W.; Park, J.H. Licoricidin, an active compound in the hexane/ethanol extract of Glycyrrhiza uralensis, inhibits lung metastasis of $4 \mathrm{t} 1$ murine mammary carcinoma cells. Int. J. Mol. Sci. 2016, 17, 934. [CrossRef] [PubMed]

142. Pham, H.N.T.; Sakoff, J.A.; Bond, D.R.; Vuong, Q.V.; Bowyer, M.C.; Scarlett, C.J. In vitro antibacterial and anticancer properties of Helicteres hirsuta lour. Leaf and stem extracts and their fractions. Mol. Biol. Rep. 2018, 45, 2125-2133. [CrossRef] [PubMed]

143. Chiu, C.T.; Chen, J.H.; Chou, F.P.; Lin, H.H. Hibiscus sabdariffa leaf extract inhibits human prostate cancer cell invasion via down-regulation of akt/nf-kb/mmp-9 pathway. Nutrients 2015, 7, 5065-5087. [CrossRef] [PubMed]

144. Koczurkiewicz, P.; Kowolik, E.; Podolak, I.; Wnuk, D.; Piska, K.; Labedz-Maslowska, A.; Wojcik-Pszczola, K.; Pekala, E.; Czyz, J.; Michalik, M. Synergistic cytotoxic and anti-invasive effects of mitoxantrone and triterpene saponins from Lysimachia ciliata on human prostate cancer cells. Planta Med. 2016, 82, 1546-1552. [CrossRef] [PubMed]

145. Shabbir, M.; Syed, D.N.; Lall, R.K.; Khan, M.R.; Mukhtar, H. Potent anti-proliferative, pro-apoptotic activity of the maytenus royleanus extract against prostate cancer cells: Evidence in in-vitro and in-vivo models. PLoS ONE 2015, 10, e0119859. [CrossRef]

146. Jahanban-Esfahlan, R.; Seidi, K.; Monfaredan, A.; Shafie-Irannejad, V.; Abbasi, M.M.; Karimian, A.; Yousefi, B. The herbal medicine melissa officinalis extract effects on gene expression of p53, bcl-2, her2, vegf-a and htert in human lung, breast and prostate cancer cell lines. Gene 2017, 613, 14-19. [CrossRef] [PubMed]

147. Jahanban-Esfahlan, A.; Modaeinama, S.; Abasi, M.; Abbasi, M.M.; Jahanban-Esfahlan, R. Anti proliferative properties of Melissa officinalis in different human cancer cells. Asian Pac. J. Cancer Prev. 2015, 16, 5703-5707. [CrossRef] [PubMed]

148. Sharma, V.; Hussain, S.; Gupta, M.; Saxena, A.K. In vitro anticancer activity of extracts of Mentha spp. Against human cancer cells. Indian J. Biochem. Biophys. 2014, 51, 416-419.

149. Emami, S.A.; Asili, J.; Hossein Nia, S.; Yazdian-Robati, R.; Sahranavard, M.; Tayarani-Najaran, Z. Growth inhibition and apoptosis induction of essential oils and extracts of Nepeta cataria L. On human prostatic and breast cancer cell lines. Asian Pac. J. Cancer Prev. 2016, 17, 125-130. [CrossRef]

150. Mollazadeh, H.; Afshari, A.R.; Hosseinzadeh, H. Review on the potential therapeutic roles of nigella sativa in the treatment of patients with cancer: Involvement of apoptosis: Black cumin and cancer. J. Pharmacopunct. 2017, 20, 158-172.

151. Uttama, S.; Itharat, A.; Rattarom, R.; Makchuchit, S.; Panthong, S.; Sakpakdeejaroen, I. Biological activities and chemical content of sung yod rice bran oil extracted by expression and soxhlet extraction methods. J. Med Assoc. Thail. Chotmaihet Thangphaet 2014, 97 (Suppl. 8), S125-S132.

152. Zhang, Z.H.; Xie, D.D.; Xu, S.; Xia, M.Z.; Zhang, Z.Q.; Geng, H.; Chen, L.; Wang, D.M.; Wei, W.; Yu, D.X.; et al. Total glucosides of paeony inhibits lipopolysaccharide-induced proliferation, migration and invasion in androgen insensitive prostate cancer cells. PLoS ONE 2017, 12, e0182584. [CrossRef] [PubMed]

153. Nguyen, V.T.; Sakoff, J.A.; Scarlett, C.J. Physicochemical properties, antioxidant and anti-proliferative capacities of dried leaf and its extract from xao tam phan (Paramignya trimera). Chem. Biodivers. 2017, 14, e1600498. [CrossRef] [PubMed] 
154. Tang, Y.Q.; Jaganath, I.B.; Manikam, R.; Sekaran, S.D. Phyllanthus spp. Exerts anti-angiogenic and anti-metastatic effects through inhibition on matrix metalloproteinase enzymes. Nutr. Cancer 2015, 67, 783-795. [CrossRef] [PubMed]

155. Nair, H.A.; Snima, K.S.; Kamath, R.C.; Nair, S.V.; Lakshmanan, V.K. Plumbagin nanoparticles induce dose and PH dependent toxicity on prostate cancer cells. Curr. Drug Deliv. 2015, 12, 709-716. [CrossRef] [PubMed]

156. Han, S.Y.; Hu, M.H.; Qi, G.Y.; Ma, C.X.; Wang, Y.Y.; Ma, F.L.; Tao, N.; Qin, Z.H. Polysaccharides from polygonatum inhibit the proliferation of prostate cancer-associated fibroblasts. Asian Pac. J. Cancer Prev. 2016, 17, 3829-3833. [PubMed]

157. Peng, C.-C.; Peng, C.-H.; Chen, K.-C.; Hsieh, C.-L.; Peng, R.Y. The aqueous soluble polyphenolic fraction of Psidium guajava leaves exhibits potent anti-angiogenesis and anti-migration actions on du145 cells. Evid. Based Complement. Altern. Med. 2011, 2011, 219069. [CrossRef] [PubMed]

158. Chen, K.C.; Peng, C.C.; Chiu, W.T.; Cheng, Y.T.; Huang, G.T.; Hsieh, C.L.; Peng, R.Y. Action mechanism and signal pathways of Psidium guajava L. Aqueous extract in killing prostate cancer lncap cells. Nutr. Cancer 2010, 62, 260-270. [CrossRef] [PubMed]

159. Albrecht, M.; Jiang, W.; Kumi-Diaka, J.; Lansky, E.P.; Gommersall, L.M.; Patel, A.; Mansel, R.E.; Neeman, I.; Geldof, A.A.; Campbell, M.J. Pomegranate extracts potently suppress proliferation, xenograft growth, and invasion of human prostate cancer cells. J. Med. Food 2004, 7, 274-283. [CrossRef] [PubMed]

160. Pantuck, A.J.; Pettaway, C.A.; Dreicer, R.; Corman, J.; Katz, A.; Ho, A.; Aronson, W.; Clark, W.; Simmons, G.; Heber, D. A randomized, double-blind, placebo-controlled study of the effects of pomegranate extract on rising psa levels in men following primary therapy for prostate cancer. Prostate Cancer Prostatic Dis. 2015, 18, 242-248. [CrossRef] [PubMed]

161. Seidi, K.; Jahanban-Esfahlan, R.; Abasi, M.; Abbasi, M.M. Anti tumoral properties of Punica granatum (Pomegranate) seed extract in different human cancer cells. Asian Pac. J. Cancer Prev. 2016, 17, 1119-1122. [CrossRef] [PubMed]

162. Ub Wijerathne, C.; Park, H.S.; Jeong, H.Y.; Song, J.W.; Moon, O.S.; Seo, Y.W.; Won, Y.S.; Son, H.Y.; Lim, J.H.; Yeon, S.H.; et al. Quisqualis indica improves benign prostatic hyperplasia by regulating prostate cell proliferation and apoptosis. Biol. Pharm. Bull. 2017, 40, 2125-2133. [CrossRef] [PubMed]

163. Kim, A.; Im, M.; Ma, J.Y. Ethanol extract of remotiflori radix induces endoplasmic reticulum stress-mediated cell death through ampk/mtor signaling in human prostate cancer cells. Sci. Rep. 2015, 5, 8394. [CrossRef] [PubMed]

164. Atmaca, H.; Bozkurt, E. Apoptotic and anti-angiogenic effects of Salvia triloba extract in prostate cancer cell lines. Tumour Biol. J. Int. Soc. Oncodev. Biol. Med. 2016, 37, 3639-3646. [CrossRef] [PubMed]

165. Chang, C.C.; Hsu, H.F.; Huang, K.H.; Wu, J.M.; Kuo, S.M.; Ling, X.H.; Houng, J.Y. Anti-proliferative effects of Siegesbeckia orientalis ethanol extract on human endometrial rl-95 cancer cells. Molecules 2014, 19, 19980-19994. [CrossRef] [PubMed]

166. Lin, H.; Jackson, G.A.; Lu, Y.; Drenkhahn, S.K.; Brownstein, K.J.; Starkey, N.J.; Lamberson, W.R.; Fritsche, K.L.; Mossine, V.V.; Besch-Williford, C.L.; et al. Inhibition of gli/hedgehog signaling in prostate cancer cells by "cancer bush" Sutherlandia frutescens extract. Cell Biol. Int. 2016, 40, 131-142. [CrossRef] [PubMed]

167. Mohammadi, A.; Mansoori, B.; Aghapour, M.; Baradaran, B. Urtica dioica dichloromethane extract induce apoptosis from intrinsic pathway on human prostate cancer cells (pc3). Cell. Mol. Biol. 2016, 62, 78-83.

168. Burton, L.J.; Rivera, M.; Hawsawi, O.; Zou, J.; Hudson, T.; Wang, G.; Zhang, Q.; Cubano, L.; Boukli, N.; Odero-Marah, V. Muscadine grape skin extract induces an unfolded protein response-mediated autophagy in prostate cancer cells: A tmt-based quantitative proteomic analysis. PLoS ONE 2016, 11, e0164115. [CrossRef] [PubMed]

169. Tsai, C.H.; Tzeng, S.F.; Hsieh, S.C.; Tsai, C.J.; Yang, Y.C.; Tsai, M.H.; Hsiao, P.W. A standardized Wedelia chinensis extract overcomes the feedback activation of her2/3 signaling upon androgen-ablation in prostate cancer. Front. Pharmacol. 2017, 8, 721. [CrossRef]

170. Tsai, C.H.; Tzeng, S.F.; Hsieh, S.C.; Lin, C.Y.; Tsai, C.J.; Chen, Y.R.; Yang, Y.C.; Chou, Y.W.; Lee, M.T.; Hsiao, P.W. Development of a standardized and effect-optimized herbal extract of Wedelia chinensis for prostate cancer. Phytomed. Int. J. Phytother. Phytopharm. 2015, 22, 406-414. [CrossRef]

171. Sarbishegi, M.; Khani, M.; Salimi, S.; Valizadeh, M.; Sargolzaei Aval, F. Antiproliferative and antioxidant effects of Withania coagulans extract on benign prostatic hyperplasia in rats. Nephro-Urol. Mon. 2016, 8, e33180. [CrossRef] 
172. Adaramoye, O.; Erguen, B.; Nitzsche, B.; Hopfner, M.; Jung, K.; Rabien, A. Antioxidant and antiproliferative potentials of methanol extract of Xylopia aethiopica (dunal) a. Rich in pc-3 and lncap cells. J. Basic Clin. Physiol. Pharmacol. 2017, 28, 403-412. [CrossRef] [PubMed]

173. Yang, Y.; Ikezoe, T.; Takeuchi, T.; Adachi, Y.; Ohtsuki, Y.; Koeffler, H.P.; Taguchi, H. Zanthoxyli fructus induces growth arrest and apoptosis of lncap human prostate cancer cells in vitro and in vivo in association with blockade of the akt and ar signal pathways. Oncol. Rep. 2006, 15, 1581-1590. [CrossRef] [PubMed]

174. Karna, P.; Chagani, S.; Gundala, S.R.; Rida, P.C.G.; Asif, G.; Sharma, V.; Gupta, M.V.; Aneja, R. Benefits of whole ginger extract in prostate cancer. Br. J. Nutr. 2012, 107, 473-484. [CrossRef] [PubMed]

175. Brahmbhatt, M.; Gundala, S.R.; Asif, G.; Shamsi, S.A.; Aneja, R. Ginger phytochemicals exhibit synergy to inhibit prostate cancer cell proliferation. Nutr. Cancer 2013, 65, 263-272. [CrossRef]

176. Khorasanchi, Z.; Shafiee, M.; Kermanshahi, F.; Khazaei, M.; Ryzhikov, M.; Parizadeh, M.R.; Kermanshahi, B.; Ferns, G.A.; Avan, A.; Hassanian, S.M. Crocus sativus a natural food coloring and flavoring has potent anti-tumor properties. Phytomed. Int. J. Phytother. Phytopharm. 2018, 43, 21-27. [CrossRef]

177. Chen, K.C.; Hsieh, C.L.; Peng, C.C.; Hsieh-Li, H.M.; Chiang, H.S.; Huang, K.D.; Peng, R.Y. Brain derived metastatic prostate cancer du-145 cells are effectively inhibited in vitro by guava (Psidium gujava L.) leaf extracts. Nutr. Cancer 2007, 58, 93-106. [CrossRef]

178. Modaeinama, S.; Abasi, M.; Abbasi, M.M.; Jahanban-Esfahlan, R. Anti tumoral properties of Punica granatum (Pomegranate) peel extract on different human cancer cells. Asian Pac. J. Cancer Prev. 2015, 16, 5697-5701. [CrossRef]

179. Mohan, A.; Nair, S.V.; Lakshmanan, V.K. Leucas aspera nanomedicine shows superior toxicity and cell migration retarded in prostate cancer cells. Appl. Biochem. Biotechnol. 2017, 181, 1388-1400. [CrossRef]

180. Bello, B.A.; Khan, S.A.; Khan, J.A.; Syed, F.Q.; Anwar, Y.; Khan, S.B. Antiproliferation and antibacterial effect of biosynthesized agnps from leaves extract of Guiera senegalensis and its catalytic reduction on some persistent organic pollutants. J. Photochem. Photobiol. Biol. 2017, 175, 99-108. [CrossRef]

181. Bello, B.A.; Khan, S.A.; Khan, J.A.; Syed, F.Q.; Mirza, M.B.; Shah, L.; Khan, S.B. Anticancer, antibacterial and pollutant degradation potential of silver nanoparticles from Hyphaene thebaica. Biochem. Biophys. Res. Commun. 2017, 490, 889-894. [CrossRef] [PubMed]

182. Liu, C.M.; Kao, C.L.; Wu, H.M.; Li, W.J.; Huang, C.T.; Li, H.T.; Chen, C.Y. Antioxidant and anticancer aporphine alkaloids from the leaves of Nelumbo nucifera gaertn. Cv. Rosa-plena. Molecules 2014, 19, 17829-17838. [CrossRef] [PubMed]

183. Arai, M.A.; Akamine, R.; Sadhu, S.K.; Ahmed, F.; Ishibashi, M. Hedgehog/gli-mediated transcriptional activity inhibitors from Crinum asiaticum. J. Nat. Med. 2015, 69, 538-542. [CrossRef] [PubMed]

184. Ramos-Torres, A.; Bort, A.; Morell, C.; Rodriguez-Henche, N.; Diaz-Laviada, I. The pepper's natural ingredient capsaicin induces autophagy blockage in prostate cancer cells. Oncotarget 2016, 7, 1569-1583. [CrossRef] [PubMed]

185. Bamji, Z.D.; Washington, K.N.; Akinboye, E.; Bakare, O.; Kanaan, Y.M.; Copeland, R.L., Jr. Apoptotic effects of novel dithiocarbamate analogs of emetine in prostate cancer cell lines. Anticancer Res. 2015, 35, 4723-4732. [PubMed]

186. Akinboye, E.S.; Rosen, M.D.; Bakare, O.; Denmeade, S.R. Anticancer activities of emetine prodrugs that are proteolytically activated by the prostate specific antigen (PSA) and evaluation of in vivo toxicity of emetine derivatives. Bioorg. Med. Chem. 2017, 25, 6707-6717. [CrossRef] [PubMed]

187. Hu, M.; Peng, S.; He, Y.; Qin, M.; Cong, X.; Xing, Y.; Liu, M.; Yi, Z. Lycorine is a novel inhibitor of the growth and metastasis of hormone-refractory prostate cancer. Oncotarget 2015, 6, 15348-15361. [CrossRef]

188. Wang, Q.; Xu, J.; Li, X.; Zhang, D.; Han, Y.; Zhang, X. Comprehensive two-dimensional pc-3 prostate cancer cell membrane chromatography for screening anti-tumor components from radix Sophorae flavescentis. J. Sep. Sci. 2017, 40, 2688-2693. [CrossRef]

189. Poornima, B.; Siva, B.; Shankaraiah, G.; Venkanna, A.; Nayak, V.L.; Ramakrishna, S.; Venkat Rao, C.; Babu, K.S. Novel sesquiterpenes from Schisandra grandiflora: Isolation, cytotoxic activity and synthesis of their triazole derivatives using "click" reaction. Eur. J. Med. Chem. 2015, 92, 449-458. [CrossRef]

190. Lan, J.; Huang, L.; Lou, H.; Chen, C.; Liu, T.; Hu, S.; Yao, Y.; Song, J.; Luo, J.; Liu, Y.; et al. Design and synthesis of novel c14-urea-tetrandrine derivatives with potent anti-cancer activity. Eur. J. Med. Chem. 2018, 143, 1968-1980. [CrossRef] 
191. Li, G.; Petiwala, S.M.; Nonn, L.; Johnson, J.J. Inhibition of chop accentuates the apoptotic effect of alpha-mangostin from the Mangosteen fruit (Garcinia mangostana) in 22rv1 prostate cancer cells. Biochem. Biophys. Res. Commun. 2014, 453, 75-80. [CrossRef] [PubMed]

192. Sato, C.; Kaneko, S.; Sato, A.; Virgona, N.; Namiki, K.; Yano, T. Combination effect of delta-tocotrienol and gamma-tocopherol on prostate cancer cell growth. J. Nutr. Sci. Vitaminol. 2017, 63, 349-354. [CrossRef] [PubMed]

193. Stadlbauer, S.; Steinborn, C.; Klemd, A.; Hattori, F.; Ohmori, K.; Suzuki, K.; Huber, R.; Wolf, P.; Grundemann, C. Impact of green tea catechin ecg and its synthesized fluorinated analogue on prostate cancer cells and stimulated immunocompetent cells. Planta Med. 2018, 84, 813-819. [CrossRef] [PubMed]

194. Busch, C.; Noor, S.; Leischner, C.; Burkard, M.; Lauer, U.M.; Venturelli, S. Anti-proliferative activity of hop-derived prenylflavonoids against human cancer cell lines. Wien. Med. Wochenschr. 2015, 165, 258-261. [CrossRef] [PubMed]

195. Afsar, T.; Trembley, J.H.; Salomon, C.E.; Razak, S.; Khan, M.R.; Ahmed, K. Growth inhibition and apoptosis in cancer cells induced by polyphenolic compounds of Acacia hydaspica: Involvement of multiple signal transduction pathways. Sci. Rep. 2016, 6, 23077. [CrossRef] [PubMed]

196. Zhu, K.C.; Sun, J.M.; Shen, J.G.; Jin, J.Z.; Liu, F.; Xu, X.L.; Chen, L.; Liu, L.T.; Lv, J.J. Afzelin exhibits anti-cancer activity against androgen-sensitive lncap and androgen-independent pc-3 prostate cancer cells through the inhibition of lim domain kinase 1. Oncol. Lett. 2015, 10, 2359-2365. [CrossRef] [PubMed]

197. Jiang, C.; Masood, M.; Rasul, A.; Wei, W.; Wang, Y.; Ali, M.; Mustaqeem, M.; Li, J.; Li, X. Altholactone inhibits nf-kappab and stat 3 activation and induces reactive oxygen species-mediated apoptosis in prostate cancer du145 cells. Molecules 2017, 22, 240. [CrossRef] [PubMed]

198. Shukla, S.; Shankar, E.; Fu, P.; MacLennan, G.T.; Gupta, S. Suppression of nf-kappab and nf-kappab-regulated gene expression by apigenin through ikappabalpha and ikk pathway in tramp mice. PLoS ONE 2015, 10, e0138710. [CrossRef] [PubMed]

199. Ryu, S.; Lim, W.; Bazer, F.W.; Song, G. Chrysin induces death of prostate cancer cells by inducing ros and er stress. J. Cell. Physiol. 2017, 232, 3786-3797. [CrossRef] [PubMed]

200. Sharma, U.K.; Sharma, A.K.; Gupta, A.; Kumar, R.; Pandey, A.; Pandey, A.K. Pharmacological activities of cinnamaldehyde and eugenol: Antioxidant, cytotoxic and anti-leishmanial studies. Cell. Mol. Biol. 2017, 63, 73-78. [CrossRef]

201. Adahoun, M.A.; Al-Akhras, M.H.; Jaafar, M.S.; Bououdina, M. Enhanced anti-cancer and antimicrobial activities of curcumin nanoparticles. Artif. CellsNanomed. Biotechnol. 2017, 45, 98-107. [CrossRef] [PubMed]

202. Chen, Q.H. Curcumin-based anti-prostate cancer agents. Anti-Cancer Agents Med. Chem. 2015, 15, 138-156. [CrossRef]

203. Dorai, T.; Cao, Y.C.; Dorai, B.; Buttyan, R.; Katz, A.E. Therapeutic potential of curcumin in human prostate cancer. III. Curcumin inhibits proliferation, induces apoptosis, and inhibits angiogenesis of lncap prostate cancer cells in vivo. Prostate 2001, 47, 293-303. [CrossRef] [PubMed]

204. Perrone, D.; Ardito, F.; Giannatempo, G.; Dioguardi, M.; Troiano, G.; Lo Russo, L.; A, D.E.L.; Laino, L.; Lo Muzio, L. Biological and therapeutic activities, and anticancer properties of curcumin. Exp. Ther. Med. 2015, 10, 1615-1623. [CrossRef] [PubMed]

205. Kumar, C.; Rasool, R.U.; Iqra, Z.; Nalli, Y.; Dutt, P.; Satti, N.K.; Sharma, N.; Gandhi, S.G.; Goswami, A.; Ali, A. Alkyne-azide cycloaddition analogues of dehydrozingerone as potential anti-prostate cancer inhibitors via the pi3k/akt/nf-kb pathway. MedChem Comm 2017, 8, 2115-2124. [CrossRef] [PubMed]

206. Jeong, M.H.; Ko, H.; Jeon, H.; Sung, G.J.; Park, S.Y.; Jun, W.J.; Lee, Y.H.; Lee, J.; Lee, S.W.; Yoon, H.G.; et al. Delphinidin induces apoptosis via cleaved hdac3-mediated p53 acetylation and oligomerization in prostate cancer cells. Oncotarget 2016, 7, 56767-56780. [CrossRef] [PubMed]

207. Hafeez, B.B.; Siddiqui, I.A.; Asim, M.; Malik, A.; Afaq, F.; Adhami, V.M.; Saleem, M.; Din, M.; Mukhtar, H. A dietary anthocyanidin delphinidin induces apoptosis of human prostate cancer pc3 cells in vitro and in vivo: Involvement of nuclear factor-kb signaling. Cancer Res. 2008, 68, 8564-8572. [CrossRef] [PubMed]

208. Naiki-Ito, A.; Chewonarin, T.; Tang, M.; Pitchakarn, P.; Kuno, T.; Ogawa, K.; Asamoto, M.; Shirai, T.; Takahashi, S. Ellagic acid, a component of pomegranate fruit juice, suppresses androgen-dependent prostate carcinogenesis via induction of apoptosis. Prostate 2015, 75, 151-160. [CrossRef] [PubMed] 
209. Eskandari, E.; Heidarian, E.; Amini, S.A.; Saffari-Chaleshtori, J. Evaluating the effects of ellagic acid on pstat3, pakt, and perk1/2 signaling pathways in prostate cancer pc3 cells. J. Cancer Res. Ther. 2016, 12, 1266-1271. [PubMed]

210. Lall, R.K.; Syed, D.N.; Khan, M.I.; Adhami, V.M.; Gong, Y.; Lucey, J.A.; Mukhtar, H. Dietary flavonoid fisetin increases abundance of high-molecular-mass hyaluronan conferring resistance to prostate oncogenesis. Carcinogenesis 2016, 37, 918-928. [CrossRef]

211. Li, X.; Yokoyama, N.N.; Zhang, S.; Ding, L.; Liu, H.M.; Lilly, M.B.; Mercola, D.; Zi, X. Flavokawain a induces deneddylation and skp2 degradation leading to inhibition of tumorigenesis and cancer progression in the tramp transgenic mouse model. Oncotarget 2015, 6, 41809-41824. [CrossRef] [PubMed]

212. Drees, M.; Dengler, W.A.; Roth, T.; Labonte, H.; Mayo, J.; Malspeis, L.; Grever, M.; Sausville, E.A.; Fiebig, H.H. Flavopiridol (186-8275): Selective antitumor activity in vitro and activity in vivo for prostate carcinoma cells. Clin. Cancer Res. 1997, 3, 273. [PubMed]

213. Wang, Y.; Tsai, M.-L.; Chiou, L.-Y.; Ho, C.-T.; Pan, M.-H. Antitumor activity of garcinol in human prostate cancer cells and xenograft mice. J. Agric. Food Chem. 2015, 63, 9047-9052. [CrossRef] [PubMed]

214. Behera, A.K.; Swamy, M.M.; Natesh, N.; Kundu, T.K. Garcinol and its role in chronic diseases. Adv. Exp. Med. Biol. 2016, 928, 435-452. [PubMed]

215. Jeon, Y.J.; Jung, S.N.; Yun, J.; Lee, C.W.; Choi, J.; Lee, Y.J.; Han, D.C.; Kwon, B.M. Ginkgetin inhibits the growth of du-145 prostate cancer cells through inhibition of signal transducer and activator of transcription 3 activity. Cancer Sci. 2015, 106, 413-420. [CrossRef] [PubMed]

216. Shirzad, M.; Heidarian, E.; Beshkar, P.; Gholami-Arjenaki, M. Biological effects of hesperetin on interleukin-6/phosphorylated signal transducer and activator of transcription 3 pathway signaling in prostate cancer pc3 cells. Pharmacogn. Res. 2017, 9, 188-194.

217. Kang, S.; Kim, J.E.; Li, Y.; Jung, S.K.; Song, N.R.; Thimmegowda, N.R.; Kim, B.Y.; Lee, H.J.; Bode, A.M.; Dong, Z; et al. Hirsutenone in alnus extract inhibits akt activity and suppresses prostate cancer cell proliferation. Mol. Carcinog. 2015, 54, 1354-1362. [CrossRef] [PubMed]

218. Lowe, H.I.C.; Toyang, N.J.; Watson, C.T.; Ayeah, K.N.; Bryant, J. Hlbt-100: A highly potent anti-cancer flavanone from Tillandsia recurvata (L.). Cancer Cell Int. 2017, 17, 38. [CrossRef]

219. Hahm, E.-R.; Karlsson, A.I.; Bonner, M.Y.; Arbiser, J.L.; Singh, S.V. Honokiol inhibits androgen receptor activity in prostate cancer cells. Prostate 2014, 74, 408-420. [CrossRef]

220. Miura, Y.; Oyama, M.; Iguchi, K.; Ito, T.; Baba, M.; Shikama, Y.; Usui, S.; Hirano, K.; Iinuma, M.; Mikamo, H. Anti-androgenic activity of icarisid II from Epimedium herb in prostate cancer lncap cells. J. Nutr. Sci. Vitaminol. 2015, 61, 201-204. [CrossRef]

221. Park, S.Y.; Lim, S.S.; Kim, J.K.; Kang, I.J.; Kim, J.S.; Lee, C.; Kim, J.; Park, J.H. Hexane-ethanol extract of glycyrrhiza uralensis containing licoricidin inhibits the metastatic capacity of du145 human prostate cancer cells. Br. J. Nutr. 2010, 104, 1272-1282. [CrossRef] [PubMed]

222. Seon, M.R.; Park, S.Y.; Kwon, S.J.; Lim, S.S.; Choi, H.J.; Park, H.; Lim, D.Y.; Kim, J.S.; Lee, C.H.; Kim, J.; et al. Hexane/ethanol extract of glycyrrhiza uralensis and its active compound isoangustone a induce g1 cycle arrest in du145 human prostate and 4t1 murine mammary cancer cells. J. Nutr. Biochem. 2012, 23, 85-92. [CrossRef] [PubMed]

223. Fang, F.; Chen, S.; Ma, J.; Cui, J.; Li, Q.; Meng, G.; Wang, L. Juglone suppresses epithelial-mesenchymal transition in prostate cancer cells via the protein kinase b/glycogen synthase kinase-3beta/snail signaling pathway. Oncol. Lett. 2018, 16, 2579-2584. [PubMed]

224. McKeown, B.T.; McDougall, L.; Catalli, A.; Hurta, R.A. Magnolol causes alterations in the cell cycle in androgen insensitive human prostate cancer cells in vitro by affecting expression of key cell cycle regulatory proteins. Nutr. Cancer 2014, 66, 1154-1164. [CrossRef] [PubMed]

225. Li, M.; Ma, H.; Yang, L.; Li, P. Mangiferin inhibition of proliferation and induction of apoptosis in human prostate cancer cells is correlated with downregulation of b-cell lymphoma-2 and upregulation of microrna-182. Oncol. Lett. 2016, 11, 817-822. [CrossRef] [PubMed]

226. Nunez Selles, A.J.; Daglia, M.; Rastrelli, L. The potential role of mangiferin in cancer treatment through its immunomodulatory, anti-angiogenic, apoptopic, and gene regulatory effects. Biofactors 2016, 42, 475-491. [CrossRef]

227. Lee, J.; Lee, S.; Kim, S.L.; Choi, J.W.; Seo, J.Y.; Choi, D.J.; Park, Y.I. Corn silk maysin induces apoptotic cell death in pc-3 prostate cancer cells via mitochondria-dependent pathway. Life Sci. 2014, 119, 47-55. [CrossRef] 
228. Shokoohinia, Y.; Hosseinzadeh, L.; Alipour, M.; Mostafaie, A.; Mohammadi-Motlagh, H.-R. Comparative evaluation of cytotoxic and apoptogenic effects of several coumarins on human cancer cell lines: Osthole induces apoptosis in p53-deficient h1299 cells. Adv. Pharmacol. Sci. 2014, 2014, 8. [CrossRef]

229. Liu, Y.; Zhang, X.; Kelsang, N.; Tu, G.; Kong, D.; Lu, J.; Zhang, Y.; Liang, H.; Tu, P.; Zhang, Q. Structurally diverse cytotoxic dimeric chalcones from Oxytropis chiliophylla. J. Nat. Prod. 2018, 81, 307-315. [CrossRef]

230. Xu, Y.; Zhu, J.Y.; Lei, Z.M.; Wan, L.J.; Zhu, X.W.; Ye, F.; Tong, Y.Y. Anti-proliferative effects of paeonol on human prostate cancer cell lines du145 and pc-3. J. Physiol. Biochem. 2017, 73, 157-165. [CrossRef]

231. Tsai, C.C.; Chuang, T.W.; Chen, L.J.; Niu, H.S.; Chung, K.M.; Cheng, J.T.; Lin, K.C. Increase in apoptosis by combination of metformin with silibinin in human colorectal cancer cells. World J. Gastroenterol. 2015, 21, 4169-4177. [CrossRef] [PubMed]

232. Sun, C.P.; Qiu, C.Y.; Yuan, T.; Nie, X.F.; Sun, H.X.; Zhang, Q.; Li, H.X.; Ding, L.Q.; Zhao, F.; Chen, L.X.; et al. Antiproliferative and anti-inflammatory withanolides from Physalis angulata. J. Nat. Prod. 2016, 79, 1586-1597. [CrossRef] [PubMed]

233. Aziz, M.H.; Dreckschmidt, N.E.; Verma, A.K. Plumbagin, a medicinal plant-derived naphthoquinone, is a novel inhibitor of the growth and invasion of hormone refractory prostate cancer. Cancer Res. 2008, 68, 9024-9032. [CrossRef] [PubMed]

234. Adaramoye, O.; Erguen, B.; Nitzsche, B.; Hopfner, M.; Jung, K.; Rabien, A. Punicalagin, a polyphenol from pomegranate fruit, induces growth inhibition and apoptosis in human pc-3 and lncap cells. Chem. Biol. Interact. 2017, 274, 100-106. [CrossRef] [PubMed]

235. Al-Jabban, S.M.; Zhang, X.; Chen, G.; Mekuria, E.A.; Rakotondraibe, L.H.; Chen, Q.H. Synthesis and anti-proliferative effects of quercetin derivatives. Nat. Prod. Commun. 2015, 10, 2113-2118. [CrossRef] [PubMed]

236. Li, X.; Chen, G.; Zhang, X.; Zhang, Q.; Zheng, S.; Wang, G.; Chen, Q.H. A new class of flavonol-based anti-prostate cancer agents: Design, synthesis, and evaluation in cell models. Bioorg. Med. Chem. Lett. 2016, 26, 4241-4245. [CrossRef] [PubMed]

237. Yang, F.; Song, L.; Wang, H.; Wang, J.; Xu, Z.; Xing, N. Quercetin in prostate cancer: Chemotherapeutic and chemopreventive effects, mechanisms and clinical application potential (review). Oncol. Rep. 2015, 33, $2659-2668$. [CrossRef] [PubMed]

238. Li, J.; Chong, T.; Wang, Z.; Chen, H.; Li, H.; Cao, J.; Zhang, P.; Li, H. A novel anticancer effect of resveratrol: Reversal of epithelialmesenchymal transition in prostate cancer cells. Mol. Med. Rep. 2014, 10, 1717-1724. [CrossRef]

239. Wang, T.T.Y.; Hudson, T.S.; Wang, T.-C.; Remsberg, C.M.; Davies, N.M.; Takahashi, Y.; Kim, Y.S.; Seifried, H.; Vinyard, B.T.; Perkins, S.N.; et al. Differential effects of resveratrol on androgen-responsive lncap human prostate cancer cells in vitro and in vivo. Carcinogenesis 2008, 29, 2001-2010. [CrossRef]

240. Berman, A.Y.; Motechin, R.A.; Wiesenfeld, M.Y.; Holz, M.K. The therapeutic potential of resveratrol: A review of clinical trials. NPJ Precis. Oncol. 2017, 1, 35. [CrossRef]

241. Lee, C.L.; Hwang, T.L.; Peng, C.Y.; Chen, C.J.; Kuo, C.L.; Chang, W.Y.; Wu, Y.C. Anti-inflammatory and cytotoxic compounds from solanum macaonense. Nat. Prod. Commun. 2015, 10, 345-348. [CrossRef] [PubMed]

242. Karakurt, S.; Adali, O. Tannic acid inhibits proliferation, migration, invasion of prostate cancer and modulates drug metabolizing and antioxidant enzymes. Anti-Cancer Agents Med. Chem. 2016, 16, 781-789. [CrossRef]

243. Ghasemi, S.; Lorigooini, Z.; Wibowo, J.; Amini-Khoei, H. Tricin isolated from allium atroviolaceum potentiated the effect of docetaxel on pc3 cell proliferation: Role of mir-21. Nat. Prod. Res. 2018, 33, 1828-1831. [CrossRef] [PubMed]

244. Klosek, M.; Mertas, A.; Krol, W.; Jaworska, D.; Szymszal, J.; Szliszka, E. Tumor necrosis factor-related apoptosis-inducing ligand-induced apoptosis in prostate cancer cells after treatment with xanthohumol-a natural compound present in Humulus lupulus L. Int. J. Mol. Sci. 2016, 17, 837. [CrossRef] [PubMed]

245. Ikemoto, K.; Shimizu, K.; Ohashi, K.; Takeuchi, Y.; Shimizu, M.; Oku, N. Bauhinia purprea agglutinin-modified liposomes for human prostate cancer treatment. Cancer Sci. 2016, 107, 53-59. [CrossRef] [PubMed]

246. Hu, E.; Wang, D.; Chen, J.; Tao, X. Novel cyclotides from Hedyotis diffusa induce apoptosis and inhibit proliferation and migration of prostate cancer cells. Int. J. Clin. Exp. Med. 2015, 8, 4059-4065. [PubMed] 
247. Gondim, A.C.S.; Romero-Canelon, I.; Sousa, E.H.S.; Blindauer, C.A.; Butler, J.S.; Romero, M.J.; Sanchez-Cano, C.; Sousa, B.L.; Chaves, R.P.; Nagano, C.S.; et al. The potent anti-cancer activity of Dioclea lasiocarpa lectin. J. Inorg. Biochem. 2017, 175, 179-189. [CrossRef] [PubMed]

248. Santha, S.; Dwivedi, C. Anticancer effects of sandalwood (Santalum album). Anticancer Res. 2015, 35, 3137-3145. [PubMed]

249. Farimani, M.M.; Taleghani, A.; Aliabadi, A.; Aliahmadi, A.; Esmaeili, M.A.; Namazi Sarvestani, N.; Khavasi, H.R.; Smiesko, M.; Hamburger, M.; Nejad Ebrahimi, S. Labdane diterpenoids from Salvia leriifolia: Absolute configuration, antimicrobial and cytotoxic activities. Planta Med. 2016, 82, 1279-1285. [CrossRef] [PubMed]

250. Wang, W.; Rayburn, E.R.; Hao, M.; Zhao, Y.; Hill, D.L.; Zhang, R.; Wang, H. Experimental therapy of prostate cancer with novel natural product anti-cancer ginsenosides. Prostate 2008, 68, 809-819. [CrossRef] [PubMed]

251. Chun, J.Y.; Tummala, R.; Nadiminty, N.; Lou, W.; Liu, C.; Yang, J.; Evans, C.P.; Zhou, Q.; Gao, A.C. Andrographolide, an herbal medicine, inhibits interleukin- 6 expression and suppresses prostate cancer cell growth. Genes Cancer 2010, 1, 868-876. [CrossRef] [PubMed]

252. Kuchta, K.; Xiang, Y.; Huang, S.; Tang, Y.; Peng, X.; Wang, X.; Zhu, Y.; Li, J.; Xu, J.; Lin, Z.; et al. Celastrol, an active constituent of the TCM plant Tripterygium wilfordii hook. F. inhibits prostate cancer bone metastasis. Prostate Cancer Prostatic Dis. 2017, 20, 156-164. [CrossRef] [PubMed]

253. Nie, C.; Zhou, J.; Qin, X.; Shi, X.; Zeng, Q.; Liu, J.; Yan, S.; Zhang, L. Diosgenininduced autophagy and apoptosis in a human prostate cancer cell line. Mol. Med. Rep. 2016, 14, 4349-4359. [CrossRef] [PubMed]

254. Silva, V.A.O.; Rosa, M.N.; Tansini, A.; Oliveira, R.J.S.; Martinho, O.; Lima, J.P.; Pianowski, L.F.; Reis, R.M. In vitro screening of cytotoxic activity of euphol from Euphorbia tirucalli on a large panel of human cancer-derived cell lines. Exp. Ther. Med. 2018, 16, 557-566. [CrossRef] [PubMed]

255. Guo, Y.X.; Lin, Z.M.; Wang, M.J.; Dong, Y.W.; Niu, H.M.; Young, C.Y.; Lou, H.X.; Yuan, H.Q. Jungermannenone $\mathrm{a}$ and $\mathrm{b}$ induce ros-and cell cycle-dependent apoptosis in prostate cancer cells in vitro. Acta Pharmacol. Sin. 2016, 37, 814-824. [CrossRef] [PubMed]

256. Sun, S.; Liu, J.; Zhou, N.; Zhu, W.; Dou, Q.P.; Zhou, K. Isolation of three new annonaceous acetogenins from graviola fruit (Annona muricata) and their anti-proliferation on human prostate cancer cell pc-3. Bioorg. Med. Chem. Lett. 2016, 26, 4382-4385. [CrossRef] [PubMed]

257. Younis, T.; Khan, M.I.; Khan, M.R.; Rasul, A.; Majid, M.; Adhami, V.M.; Mukhtar, H. Nummularic acid, a triterpenoid, from the medicinal plant Fraxinus xanthoxyloides, induces energy crisis to suppress growth of prostate cancer cells. Mol. Carcinog. 2018, 57, 1267-1277. [CrossRef]

258. Singh, S.; Dubey, V.; Singh, D.K.; Fatima, K.; Ahmad, A.; Luqman, S. Antiproliferative and antimicrobial efficacy of the compounds isolated from the roots of Oenothera biennis L. J. Pharm. Pharmacol. 2017, 69, 1230-1243. [CrossRef]

259. Akhtar, N.; Syed, D.N.; Khan, M.I.; Adhami, V.M.; Mirza, B.; Mukhtar, H. The pentacyclic triterpenoid, plectranthoic acid, a novel activator of ampk induces apoptotic death in prostate cancer cells. Oncotarget 2016, 7, 3819-3831. [CrossRef]

260. Piao, L.; Canguo, Z.; Wenjie, L.; Xiaoli, C.; Wenli, S.; Li, L. Lipopolysaccharides-stimulated macrophage products enhance withaferin a-induced apoptosis via activation of caspases and inhibition of nf-kappab pathway in human cancer cells. Mol. Immunol. 2017, 81, 92-101. [CrossRef]

261. Panichayupakaranant, P.; Ahmad, M.I. Plumbagin and its role in chronic diseases. Adv. Exp. Med. Biol. 2016, 929, 229-246. [PubMed]

262. Jiang, C.; Lee, H.J.; Li, G.X.; Guo, J.; Malewicz, B.; Zhao, Y.; Lee, E.O.; Lee, H.J.; Lee, J.H.; Kim, M.S.; et al. Potent antiandrogen and androgen receptor activities of an angelica gigas-containing herbal formulation: Identification of decursin as a novel and active compound with implications for prevention and treatment of prostate cancer. Cancer Res. 2006, 66, 453-463. [CrossRef] [PubMed]

263. Prasad, R.; Katiyar, S.K. Honokiol, an active compound of magnolia plant, inhibits growth, and progression of cancers of different organs. Adv. Exp. Med. Biol. 2016, 928, 245-265. [PubMed]

264. Dybkowska, E.; Sadowska, A.; Swiderski, F.; Rakowska, R.; Wysocka, K. The occurrence of resveratrol in foodstuffs and its potential for supporting cancer prevention and treatment. A review. Rocz. Panstw. Zakl. Hig. 2018, 69, 5-14. [PubMed]

265. Perabo, F.G.E.; von Löw, E.C.; Siener, R.; Ellinger, J.; Müller, S.C.; Bastian, P.J. [a critical assessment of phytotherapy for prostate cancer]. Urol. A 2009, 48, 270-271, 274-283. 
266. Wu, C.Y.; Yang, Y.H.; Lin, Y.Y.; Kuan, F.C.; Lin, Y.S.; Lin, W.Y.; Tsai, M.Y.; Yang, J.J.; Cheng, Y.C.; Shu, L.H.; et al. Anti-cancer effect of danshen and dihydroisotanshinone i on prostate cancer: Targeting the crosstalk between macrophages and cancer cells via inhibition of the stat3/ccl2 signaling pathway. Oncotarget 2017, 8, 40246-40263. [CrossRef] [PubMed]

267. Liu, J.-M.; Lin, P.-H.; Hsu, R.-J.; Chang, Y.-H.; Cheng, K.-C.; Pang, S.-T.; Lin, S.-K. Complementary traditional chinese medicine therapy improves survival in patients with metastatic prostate cancer. Medicine 2016, 95, e4475. [CrossRef] [PubMed]

268. Pantuck, A.J.; Leppert, J.T.; Zomorodian, N.; Aronson, W.; Hong, J.; Barnard, R.J.; Seeram, N.; Liker, H.; Wang, H.; Elashoff, R.; et al. Phase ii study of pomegranate juice for men with rising prostate-specific antigen following surgery or radiation for prostate cancer. Clin. Cancer Res. Off. J. Am. Assoc. Cancer Res. 2006, 12, 4018-4026. [CrossRef]

269. Pantuck, A.J.; Leppert, J.T.; Zomorodian, N.; Seeram, N.; Seiler, D.; Liker, H.; Wang, H.-j.; Elashoff, R.; Heber, D.; Belldegrun, A.S. 831: Phase ii study of pomegranate juice for men with rising PSA following surgery or radiation for prostate cancer. J. Urol. 2005, 173, 225-226. [CrossRef]

270. Paller, C.J.; Ye, X.; Wozniak, P.J.; Gillespie, B.K.; Sieber, P.R.; Greengold, R.H.; Stockton, B.R.; Hertzman, B.L.; Efros, M.D.; Roper, R.P.; et al. A randomized phase ii study of pomegranate extract for men with rising psa following initial therapy for localized prostate cancer. Prostate Cancer Prostatic Dis. 2013, 16, 50-55. [CrossRef]

271. Thomas, R.; Williams, M.; Sharma, H.; Chaudry, A.; Bellamy, P. A double-blind, placebo-controlled randomised trial evaluating the effect of a polyphenol-rich whole food supplement on psa progression in men with prostate cancer-The UK NCRN pomi-t study. Prostate Cancer Prostatic Dis. 2014, 17, 180. [CrossRef] [PubMed]

272. Alumkal, J.J.; Slottke, R.; Schwartzman, J.; Cherala, G.; Munar, M.; Graff, J.N.; Beer, T.M.; Ryan, C.W.; Koop, D.R.; Gibbs, A.; et al. A phase ii study of sulforaphane-rich broccoli sprout extracts in men with recurrent prostate cancer. Investig. New Drugs 2015, 33, 480-489. [CrossRef] [PubMed]

273. Kjaer, T.N.; Ornstrup, M.J.; Poulsen, M.M.; Jorgensen, J.O.; Hougaard, D.M.; Cohen, A.S.; Neghabat, S.; Richelsen, B.; Pedersen, S.B. Resveratrol reduces the levels of circulating androgen precursors but has no effect on, testosterone, dihydrotestosterone, psa levels or prostate volume. A 4-month randomised trial in middle-aged men. Prostate 2015, 75, 1255-1263. [CrossRef] [PubMed]

274. Paller, C.J.; Rudek, M.A.; Zhou, X.C.; Wagner, W.D.; Hudson, T.S.; Anders, N.; Hammers, H.J.; Dowling, D.; King, S.; Antonarakis, E.S.; et al. A phase i study of muscadine grape skin extract in men with biochemically recurrent prostate cancer: Safety, tolerability, and dose determination. Prostate 2015, 75, 1518-1525. [CrossRef] [PubMed]

275. De La Taille, A.; Buttyan, R.; Hayek, O.; Bagiella, E.; Shabsigh, A.; Burchardt, M.; Burchardt, T.; Chopin, D.K.; Katz, A.E. Herbal therapy pc-spes: In vitro effects and evaluation of its efficacy in 69 patients with prostate cancer. J. Urol. 2000, 164, 1229-1234. [CrossRef]

(C) 2019 by the authors. Licensee MDPI, Basel, Switzerland. This article is an open access article distributed under the terms and conditions of the Creative Commons Attribution (CC BY) license (http://creativecommons.org/licenses/by/4.0/). 